\title{
A SerpinB2 és a SerpinB10 szerepe a DNS hibajavításban és a tumoros folyamatokban
}

\author{
Ph.D. értekezés
}

\author{
Készítette: Majoros Hajnalka \\ Témavezetők: Prof. Dr. Boros Imre Miklós \\ Dr. habil. Pankotai Tibor
}

Biológia Doktori Iskola

\author{
Szegedi Tudományegyetem \\ Természettudományi és Informatikai Kar \\ Biokémiai és Molekuláris Biológiai Tanszék
}

Szeged

2019 


\section{Tartalomjegyzék}

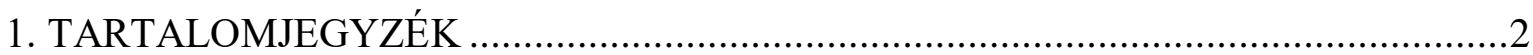

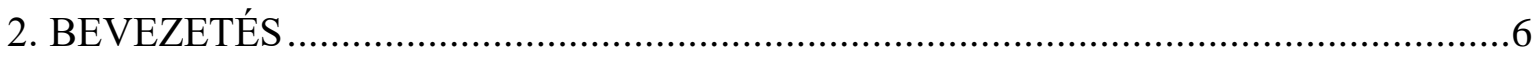

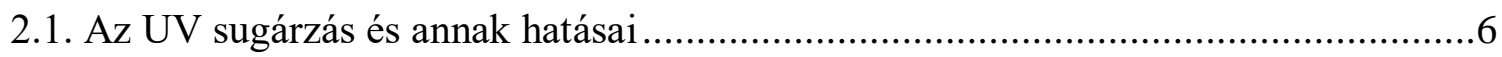

2.2. Nukleotid kivágó hibajavítás (NER) …….....................................................

2.2.1. Teljes genomra kiterjedő nukleotid kivágó hibajavítás (GG-NER)....................8

2.2.2. Transzkripció kapcsolt nukleotid kivágó hibajavítás (TC-NER)......................12

2.2.3. A transzkripció kapcsolt és a teljes genomra kiterjedő nukleotid kivágó

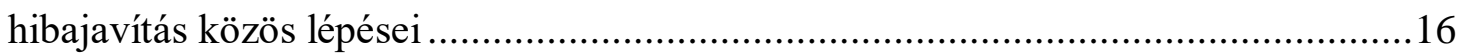

2.3. Az UV hatására kialakuló tumoros folyamatok biokémiai háttere ........................18

2.4. Bőr eredetü sejtekből kialakuló tumortípusok ....................................................20

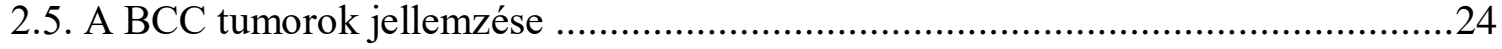

2.6. Serpinek: Szerin proteáz inhibítor (SP) fehérjecsalád ....................................26

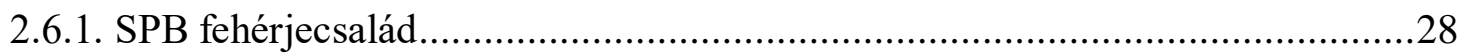

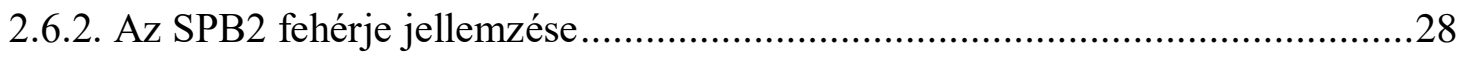

2.6.3. Az SPB10 fehérje jellemzése ............................................................... 30

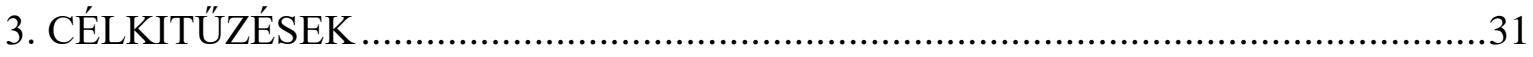

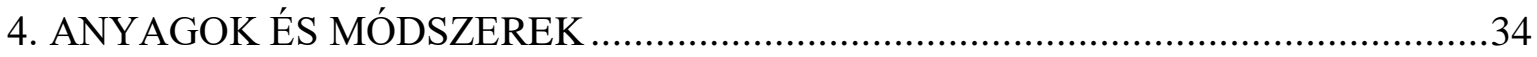

4.1. Hker E6SFM, HaCaT, A375, U2OS és U2OS17 sejtek fenntartása .......................34

4.2. Humán sejtek viabilitásának mérése tripánkék festékkel ..................................34

4.3. Humán sejtek életképességének mérése kristályibolya oldattal...........................35

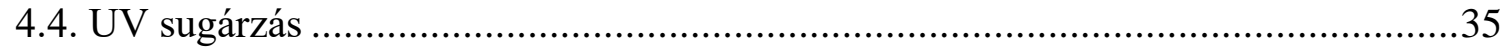

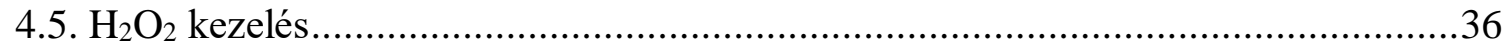

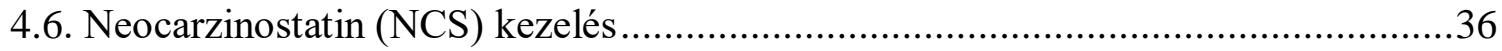

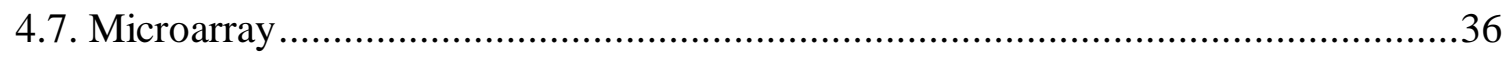

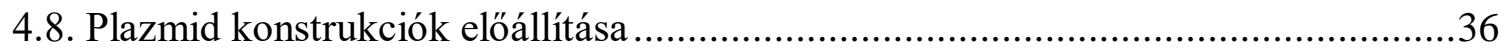


4.9. Baktérium transzformáció és plazmid tisztítás

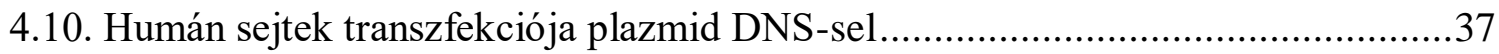

4.11. RNS izolálás humán sejtekből és reverz transzkripciós reakció ...........................38

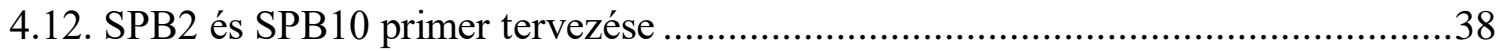

4.13. Génexpresszió mérése kvantitatív real time PCR (qPCR) technikával ..................38

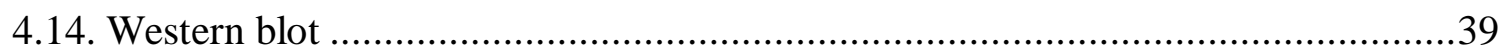

4.15. Frakcionált sejtlizátum készítése Western blot technikához...............................40

4.16. CSK immunhiszokémiai eljárás alkalmazása humán sejteken ...........................41

4.17. Immunhisztokémiai eljárás alkalmazása humán sejteken ................................42

4.18. Immunhisztokémia humán szöveteken .........................................................43

4.19. A humán szövetek hematoxilin és eozin festése …........................................44

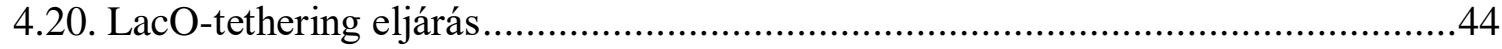

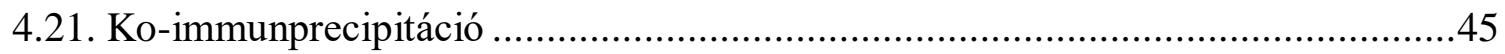

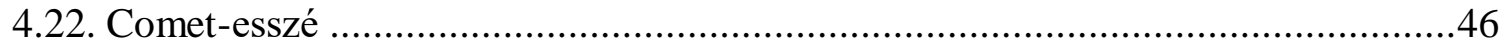

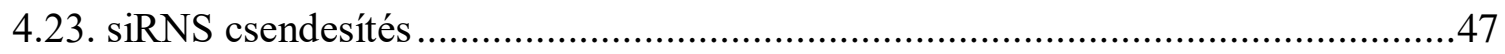

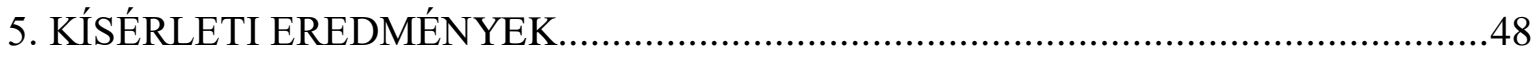

5.1. Microarray eredmények UV kezelt Hker E6SFM sejteken ................................48

5.2. Különböző koncentrációjú, illetve erősségű DNS károsító ágensek félletális

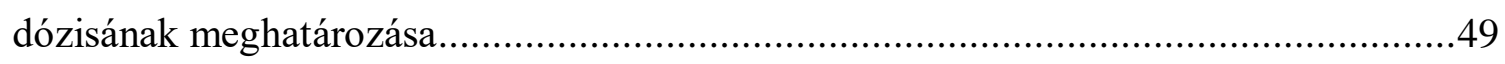

5.3. SPB2 UV sugárzás hatására kialakuló sejtválaszban betöltött szerepe ....................51

5.3.1. UV kezelés hatására az SPB2 relatív mRNS szintje megemelkedik a vizsgált

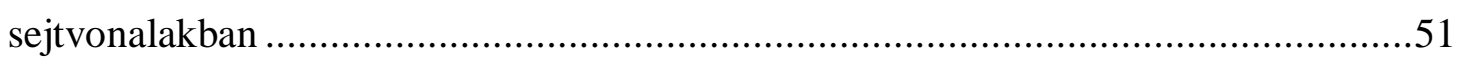

5.3.2. UV kezelés hatására az SPB2 fehérje szintje megemelkedik a vizsgált sejtvonalakban

5.3.3. UV kezelés hatására az SPB2 fehérje sejten belüli elhelyezkedése megváltozik a

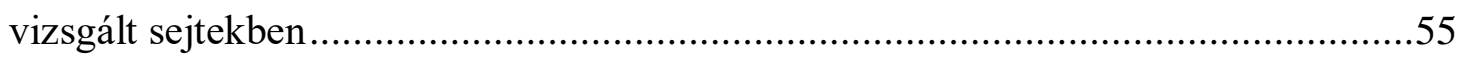


5.3.4. Különböző stresszhatások következtében az SPB2 fehérje fókuszokat alakít ki a sejtmagban 59

5.3.5. Az SPB2 és a Nukleotid Kivágó Hibajavításban szerepet játszó fehérje, az XPB (Xeroderma pigmentosum B) együttes lokalizációja figyelhető meg UV kezelés hatására.

5.3.6. Az SPB2 és a Nukleotid Kivágó Hibajavításban szerepet játszó fehérje, az XPB (Xeroderma pigmentosum B) együttes lokalizációja ellenére a két fehérje között nem mutatható ki kölcsönhatás .68

5.3.7. LacO rendszer bemutatása. 70

5.3.8. Az XPB kihorgonyzását követően az SPB2 ko-lokalizációt mutat a NER komplexszel. .71

5.3.9. Az SPB2 és az RNS Polimeráz II komplex kölcsönhatásának vizsgálata. 73

5.3.10. Az UV sugárzás hatására kialakuló ubiquitilált környezetben kimutatható az SPB2 fehérje jelenléte

5.3.11. Az SPB2 fehérje lokalizációja eltérő kontroll és BCC (bazális sejtes karcinóma) tumoros szövetminták között

5.4. SPB10 UV sugárzás hatására kialakuló sejtválaszban betöltött szerepe 80

5.4.1. UV kezelés hatására az SPB10 relatív mRNS szintje megemelkedik a vizsgált sejtvonalakban

5.4.2. Az SPB10 fehérje csendesítése nem befolyásolja a sejtek túlélését .81

5.4.3. Az SPB10 fehérje csendesítése befolyásolja a DNS hibajavítás gyorsaságát ....82

5.4.4. Az SPB10 kölcsönhat a H3 fehérjével .85

6. EREDMÉNYEK MEGVITATÁSA 87

7. KÖSZÖNETNYILVÁNÍTÁS .94

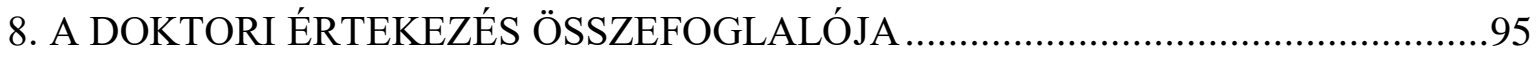

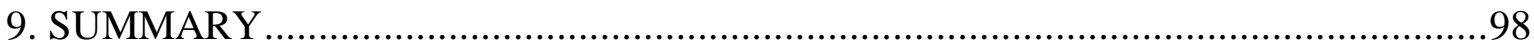

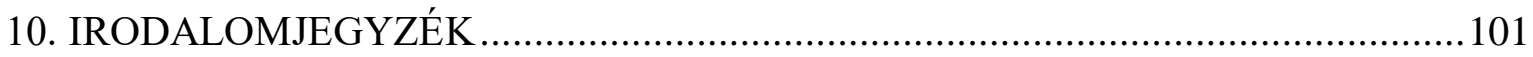

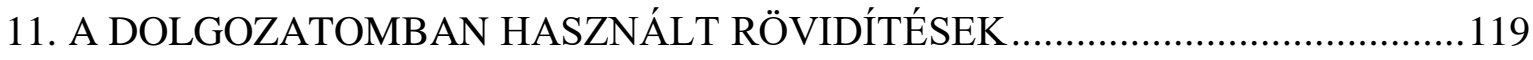

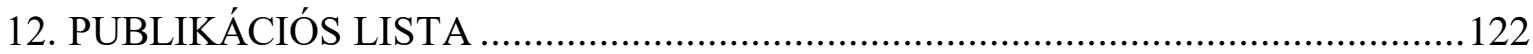




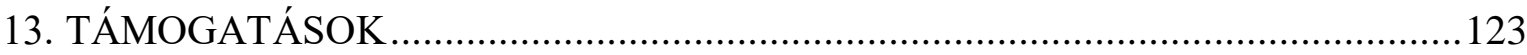




\section{Bevezetés}

\subsection{Az UV sugárzás és annak hatásai}

Sejtjeinket életünk során folyamatosan külső és belső forrásból származó károsító hatások érik. A külső források közül a börsejtekre leginkább destruktív hatás a Napból a Földre érkező ultraibolya (UV) sugárzás. Az UV a látható fénynél rövidebb hullámhosszú, 200-400 nanométeres $(\mathrm{nm})$ tartományba eső elektromágneses sugárzás. Hullámhossza alapján három főbb típust különböztetünk meg: (I) UVA (315-400 nm), (II) UVB (280-315 nm) és az (III) UVC (200-280 nm) sugárzás (1. ábra). A Földet körülvevő ózonréteg megszüri a rövidebb hullámhosszú sugarakat, így a földfelszínt és ezáltal a bőrünket ért sugárzások közül az UVB a bőr dermisz rétegéig, míg az UVA a hipodermiszig hatolhat ${ }^{1-5}$. Az UV sugárzás típusait az 1. ábra szemlélteti. Az ózon réteg sérülése miatt nem történik meg a teljes UVC spektrum kiszürésre, és ezzel a sugárzással is számolnunk kell, mint szervezetünket érintő sejtkárosító hatás. Az UV sugárzásnak hatására számos káros fiziológiai és biológia következménye van szervezetünkben, ilyen például a sejtöregedés, immunszupresszió, gyulladásos folyamatok kiváltása, DNS károsodás, vagy akár apoptotikus folyamatok inicializációja ${ }^{6,7}$. Az UV sugárzás közvetlenül, vagy számos faktor által, mint például a reaktív oxigéngyökök (ROS), képes közvetetten is olyan DNS károsodások kiváltására, melyek mutációkhoz és módosult génexpresszióhoz vezethetnek. Ezek végső soron pedig a normál sejtműködéstől eltérő, úgynevezett tumoros folyamatok elindulását eredményezhetik ${ }^{4,8,9}$. Az UV sugárzás hatására kialakuló DNS károsodások fajtáját elsősorban a sugárzás hullámhossza határozza meg. UVA sugárzás hatására főként oxidatív DNS módosítások figyelhetők meg, mint például a 8-hidroxiguanin képződés, DNS-fehérje keresztkötések kialakulása, továbbá létrejöhetnek abázikus helyek, valamint akár egyes-szálú DNS törések ${ }^{3,10}$. A rövidebb hullámhosszú UVB és UVC sugárzás jellemzően inkább direkt módon károsítja a DNS-t, ezek hatására ciklobután pirimidin dimerek (CPD), vagy 6-4 pirimidin-pirimidon fototermékek (6-4 PP) alakulnak $\mathrm{ki}^{11,12}$.

Mivel az emberi bőr az elsődleges védelmi vonal a károsító hatások elleni védekezésben, így ezen szervünk van a leginkább kitéve az UV sugárzás okozta destruktív hatásoknak. Így nem meglepő módon az UV sugárzás a fö kiváltó oka a humán bőr eredetű tumorok kialakulásának, melyek lehetnek melanoma- (mely a bőr pigmentsejteiből kialakuló rosszindulatú daganat) és nem-melanoma típusú daganatok, köztük bazális sejtes karcinóma (BCC), valamint elszarusodó laphámrák (SCC) ${ }^{13,14}$. 


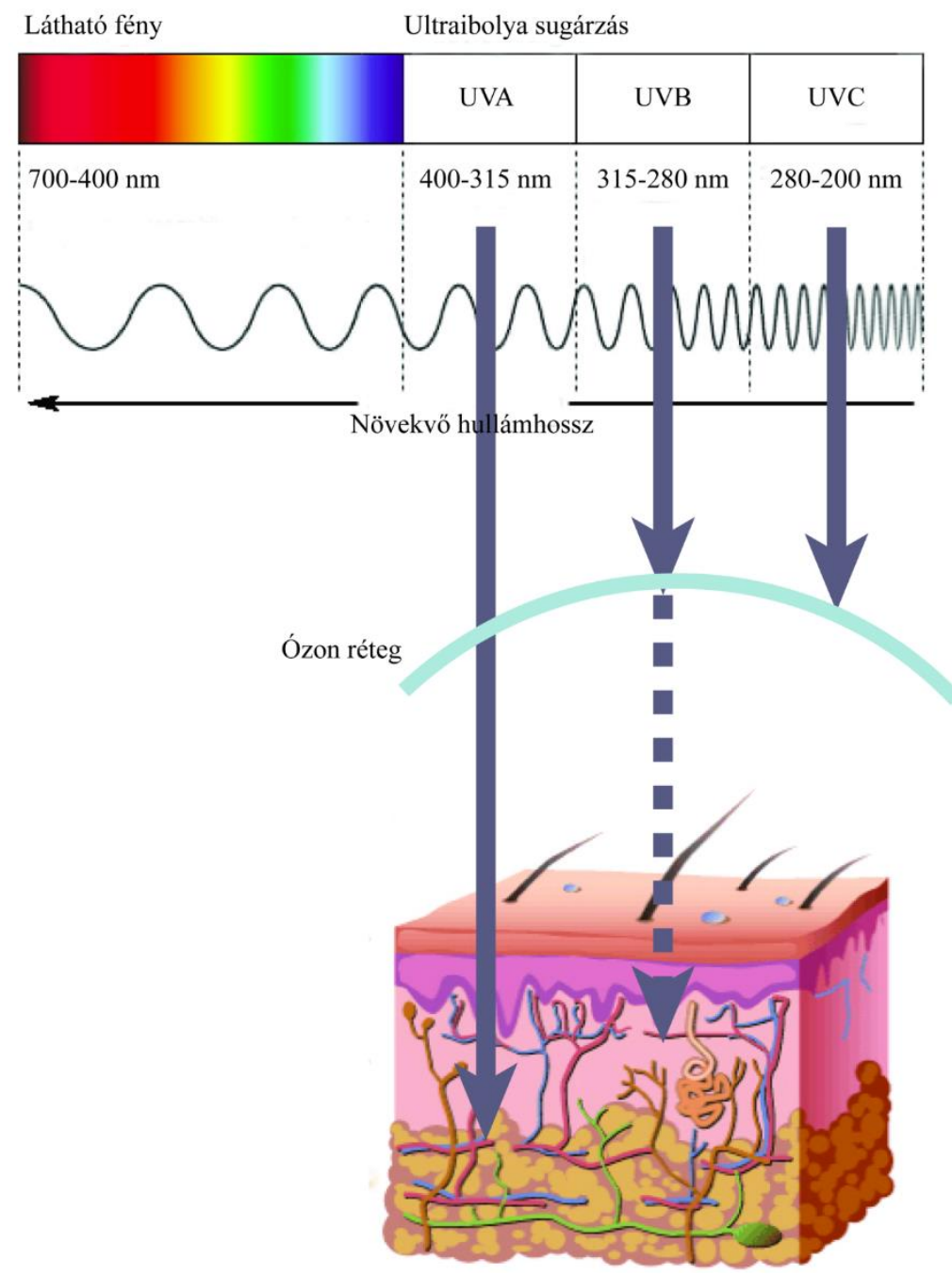

\section{1. ábra: UV sugárzás típusai és elnyelődésük a bőr rétegeiben:}

Az UV sugárzások hullámhosszuktól függően a bőr különböző rétegéig képesek hatolni. Az ábra a Bright Vision Optometry és az AIM (At Melanoma Foundation) oldalak alapján készült.

\subsection{Nukleotid kivágó hibajavítás (NER)}

A genom folyamatos külső és belső forrásból származó DNS károsító ágenseknek van kitéve, így egy emlős sejtben naponta mintegy $10^{4}-10^{6}$ DNS hiba keletkezik ${ }^{15}$. Ezeket a DNS károsodásokat rövid idő alatt, precízen javítani kell, hisz a rosszul, vagy nem megfelelően kijavított léziók a DNS intaktságának elvesztését, a replikáció megállását, mutagenezist, illetve kromoszóma aberrációkat eredményezhetnek. Mindezek a hibák onkogének aktivációjához és tumorszupresszorok inaktivációjához vezethetnek, mellyel a 
tumorképződés kockázata is megnövekedhet. A szervezet a DNS sérülés mentes megörzésére számos DNS hibajavító útvonalat fejlesztett ki. Ezen útvonalakban közös elemek a hibát felismerő szenzor molekulák és szignalizációs kinázok, melyek számos, az útvonalban később aktiválódó mediátor és effektor molekulát szabályoznak, ezáltal koordinálva a DNS hibajavítást, a sejtciklust és a sejt sorsát ${ }^{16}$. A DNS hibajavító útvonalak közül a nukleotid kivágó javító mechanizmus (NER- nucleotide excision repair) egy kivételes típus, hiszen a többitől eltérően, számos strukturálisan különböző DNS lézió javítására alkalmas. Ilyen például az UV indukálta ciklobután pirimidin dimer (CPD), 6-4 pirimidin-pirimidon fototermék (6-4 PP), vagy a kémiailag indukált bulky adduct, továbbá a különböző drogok, például cisplatin okozta DNS szálak közötti keresztkötések, és akár a reaktív oxigéngyökök (ROS) kiváltotta ciklopurinok ${ }^{17}$. Más DNS hibajavító útvonalhoz hasonlóan, a NER is számos alfolyamatból áll, többek között a hiba felismeréséböl, majd a hibát tartalmazó DNS szál 22-30 nukleotidnyi szakaszának eltávolításából, valamint a kivágott rész pótlásából. A DNS lézió felismerése, illetve a javító mechanizmus helyének és idejének aktivációja alapján két nukleotid kivágó javítómechanizmust különböztetünk meg: a teljes genomra kiterjedő GG-NER-t (global genomic NER), valamint a transzkripció kapcsolt TC-NER-t (transcription coupled). Ezen altípusok, csak a DNS hiba felismerési szakaszában különböznek egymástól, a többi részfolyamat azonos módon történik. A GGNER esetében a DNS-hélix torzulását okozó hibák aktiválják a mechanizmust a teljes genomban, függetlenül a hiba helyzetétől, míg a TC-NER esetében olyan hibákat ismer fel az útvonal, melyek megakadályozzák az elongáló RNS polimeráz II továbbhaladását a templát DNS-en, vagyis transzkripciós blokkot idéznek elö.

\subsubsection{Teljes genomra kiterjedő nukleotid kivágó hibajavítás (GG-NER)}

A GG-NER-ben a fö hibafelismerő szenzor fehérje az XPC (Xeroderma pigmentosum C), mely a Rad23B és a centrin 2 (CETN2) molekulákkal képez komplexet, és a 3 fehérje összekapcsolódva DNS hélix-disztorziók felismerését végzi ${ }^{18-20}$. Ha DNS torzulást észlel, a komplex a hibával szembeni szálhoz kötődik, majd a Rad23B disszociál a komplexről. Ezzel befejezve a hibafelismerő szakaszt, és elindítva a hiba jelenlétének igazolását. Kimutatták, hogy számos hibához, melyet az XPC komplex in vivo képes felismeri, in vitro körülmények között nem tud kötődi ${ }^{21}$. Ezt a jelenséget az ún. két lépéses felismerő modellel magyarázták, mely szerint az XPC bekötése után a hiba meglétét igazolni kell, amihez további fehérjék szükségesek 21,22. Azt is kimutatták, hogy a Rad4, mely az XPC ortológja sarjadzó 
élesztőkben, hogyan képes a DNS torzulások felismerésére. Az XPC a hibával szembeni DNS szálhoz kötődik, majd a karboxi-terminális végén elhelyezkedő dupla $\beta$-hairpin doménjét helyezi be a DNS két szála közé a dsDNS (double stranded) és az ssDNS (single stranded) találkozási pontjánál, ezzel egyszerre felismerve és megnövelve a DNS disztorziót 23. Azonban kiderült, hogy a CPD hibák hiába okoznak eltérést a hélixben, az XPC önmagában ezen léziókat nem, vagy csak igen nehezen ismeri fel ${ }^{21,24}$.
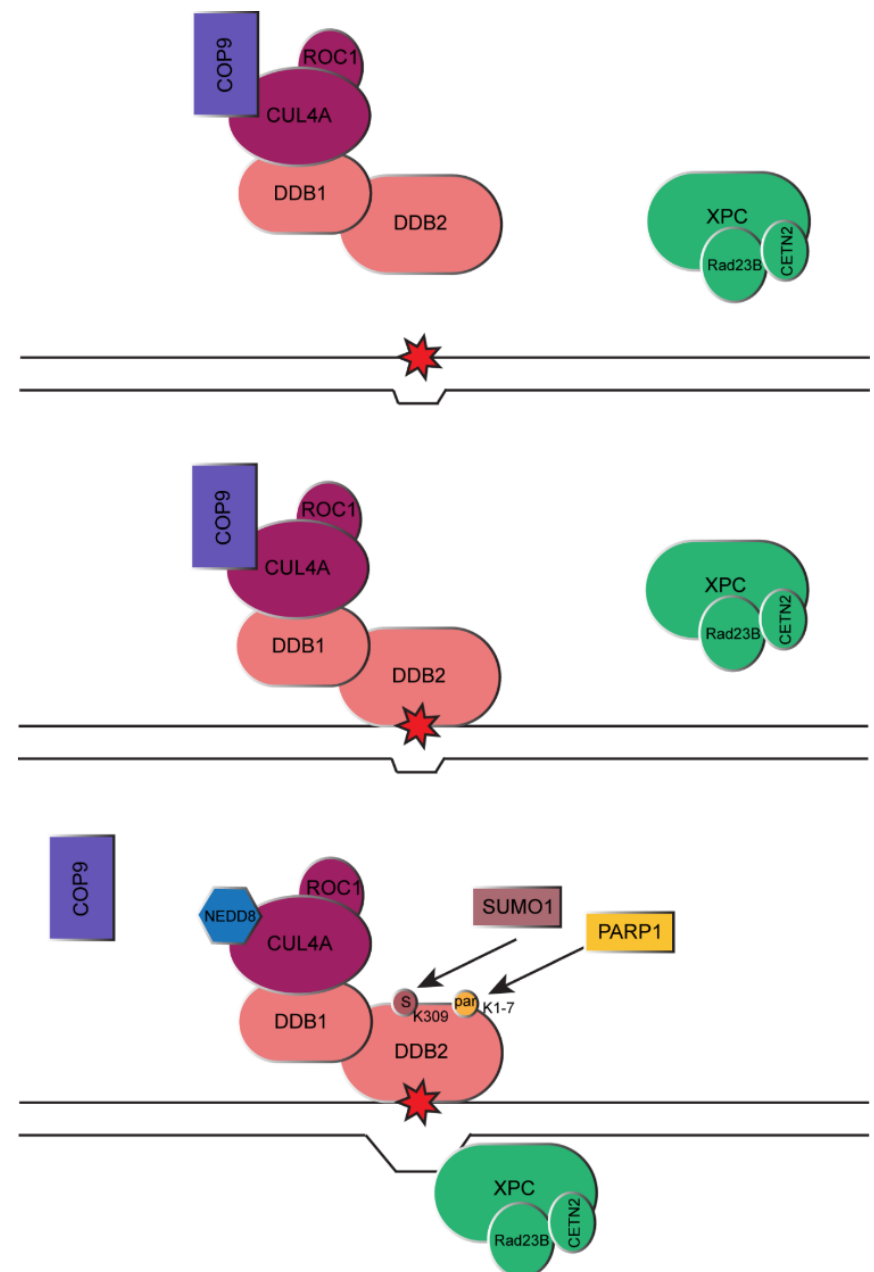

2. a ábra: A teljes genomra kiterjedő nukleotid kivágó hibajavító (GG-NER) útvonal
hibafelismerési szakasza. Az XPC komplex a hibával szembeni DNS szálhoz
kapcsolódik. A CPD hibák esetében az UV-DDB-komplex segíti a hibafelismerést, mely
aktivitását különböző PTM módosítások szabályozzák.

Ezen hibák felismerésében egy további komplex, az UV-DDB-komplex (Ultraviolet radiation DNA damage- binding protein) segít az XPC-nek, mely az UV indukálta DNS hibához kötődik, majd kihurkolva a DNS szálat létrehoz egy nagyobb szakaszú ssDNS torziót, ezzel elősegítve az XPC hibafelismerését ${ }^{25,26}$. Az UV-DDB komplex két tagból 
tevődik össze, a linker DDB1 fehérjéböl, valamint a DDB2-ből, mely egy DCAF (DDB1 and Cul4- associated factors) molekula, mely WD40-DNS kötő doménje segítségével kapcsolódik a hibához ${ }^{27}$. Az UV-DDB egy másik, a CRL-komplex-szel (Cullin-RING ubiquitin ligase) alkot egy nagyobb egységet, mely saját magát és környezetét is szabályozza a hibafelismerés során ${ }^{28}$. A CRL-komplex két proteinből áll: a Cul4A fehérjéből, mely egy E3 ubiquitin ligáz, valamint a Roc1 E2 ubiquitin konjugáló enzimből.

Az UV sugárzás okozta hibafelismerés során összeáll az ún. CRL ${ }^{\text {DDB2 }}$ komplex. Ezen komplex alap esetben a COP9 (Constitutive photomorphogenesis 9) fehérje negatív szabályozó hatása miatt inaktív állapotban található. A komplex hibához történő lokalizációjakor, a COP9 protein disszociál a komplexről, ezzel szabaddá téve a NEDD8 felismerő helyét a komplexen, mely hozzákötődésével neddilálja a $\mathrm{CRL}^{\mathrm{DDB} 2}-\mathrm{t}{ }^{29,30}$ (2. a ábra). Az aktív CRL ${ }^{\mathrm{DDB} 2}$ komplex számos fehérje ubiquitilációját végzi, például a környező hiszton fehérjéket (H2A, H3, H4), mellyel közvetlenül, illetve számos segítőfehérje részvételével közvetetten, a kromatin fellazulását eredményezi ${ }^{31-33}$. Továbbá az XPC fehérje is ubiquitilálódik ebben a folyamatban, azonban ez nem jár annak proteoszómális lebomlásával, hanem az XPC DNS-hez való erősebb kötődését eredményezi ${ }^{34}$. Továbbá a CRL komplex önmagát is, pontosabban a DDB2 fehérjét ubiquitilálja, mely ezáltal degradálódik ${ }^{35}$. Azonban, mivel a DDB2 hibánál való jelenléte szükséges az XPC toborzásához, így e folyamat sokrétủen és pontosan szabályozott. Többek között a DDB2-t az USP24 deubiquitilálhatja, meggátolva ezáltal annak lebontását (2. b ábra). Ismeretes, hogy a PARP1 képes a DDB2 fehérje parilálására, ezzel stabilizálva annak szerkezetét ${ }^{36-38}$. Ennek a poszttranszlációs módosításnak az a különlegessége, hogy a DDB2 fehérjének ugyanazon N-terminális doménjén található 7 darab lizin oldalláncon történhet meg, mint amely ubiquitilálódhat is, így a két poszttranszlációs módosítás (PTM) egyszerre nem fordulhat elö, vagyis a DDB2 parilációja egyben gátlás is annak ubiquitilációjával szemben 39. UV sugárzás hatására a DDB2 a pariláció mellett szumoilálódik is, melyet a SUMO-1 enzim hajt végre ${ }^{40}$. A DDB2 együttes szumoilációja és parilációja szükséges ahhoz, hogy az XPC fehérje a hibához lokalizálódjon ${ }^{41,42}$ (2. a ábra). Az XPC hibafelismerése után az UV-DDB komplex disszociál a DNS-ről (DDB2 proteoszómális lebontása révén), átadva a 
helyét a következő hibafelismerő fehérjének, az XPA-nak. Az XPC fehérje DNS hibához történő kötődésének erőssége és hossza kiemelt jelentőségű a folyamat szabályozásában.
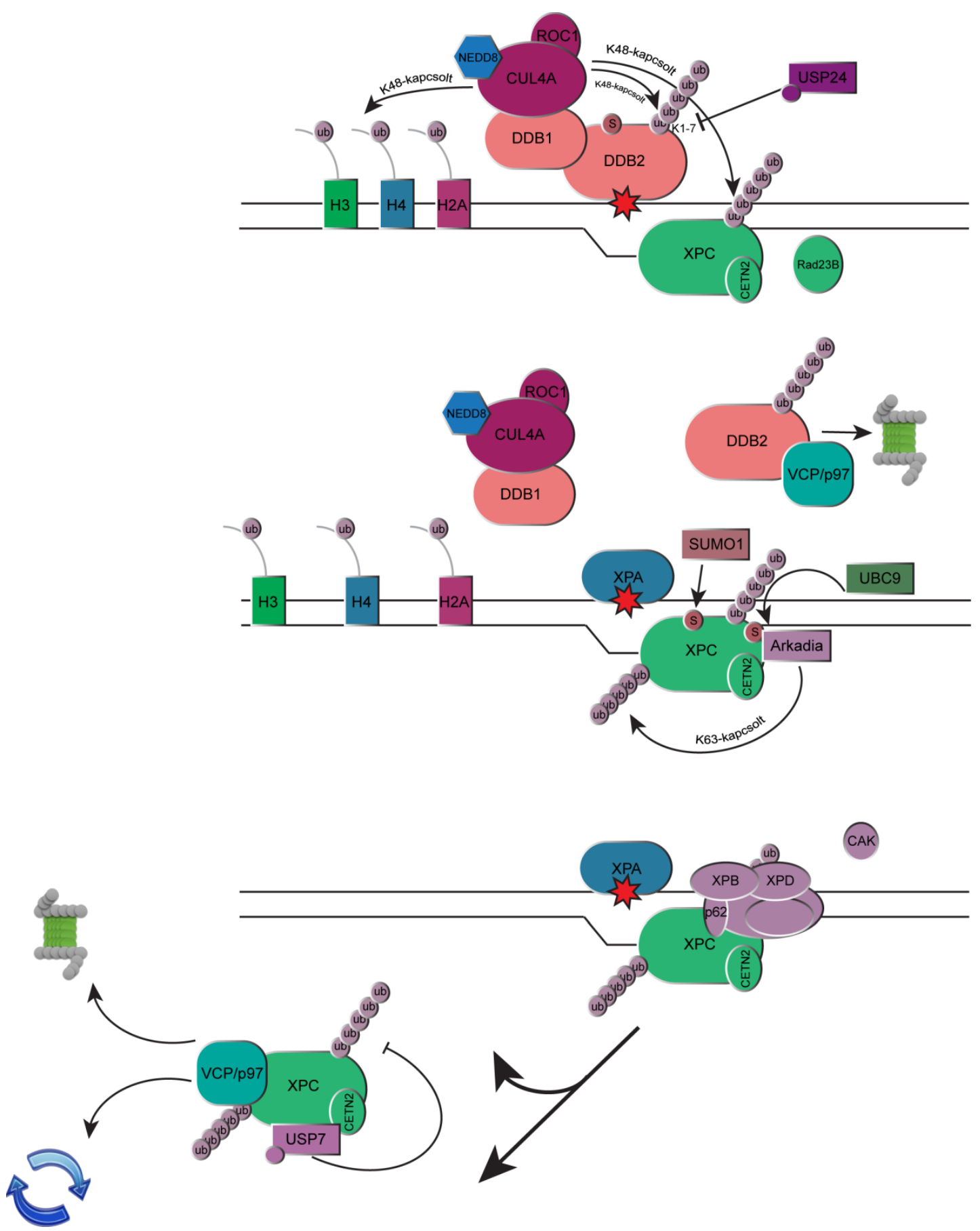

3. b ábra: A teljes genomra kiterjedő nukleotid kivágó hibajavító (GG-NER) útvonal hibafelismerési szakaszának második fele. E3 szumo és ubiquitin ligázok, valamint deubiquitilázok jelentős szerepet játszanak az XPC és DDB2 fehérjék aktivitásának szabályzásában. 
Említésre került már, hogy $\mathrm{CRL}^{\mathrm{DDB} 2}$ komplex képes K-48 oldalláncon ubiquitilálni, mely erősíti az XPC DNS-hez való kötődését. Ezen ubiquitilációs jelet az USP7 deubiquitiláz enzim képes eltávolítani, mely folyamat valószínűleg akkor történik, mikor már nincs szükség az XPC és a DNS erős kapcsolatára ${ }^{43}$. Azonban a K-48 ubiquitilációs jel szükséges ahhoz, hogy az XPC-t a SUMO-1 enzim DDB2, és XPA fehérje függő módon szumoilálja 44,45. Az XPC-t az UBC9 is szumoilálja egy további pozícióban ${ }^{46,47}$. Ezen második szumoilációs módosítást képes felismerni és ezáltal az XPC-hez kötődni az Arkadia (RNF111) fehérje, mely ezután K-63 oldalláncon poliubiquitilálja az XPC-t ${ }^{48}$. Ez egy igen fontos lépés a GG-NER hibafelismerésben, valamint ezen módosítás is szabályozza az XPC DNS lézióhoz történő kapcsolódását ${ }^{46,49-52}$. Az XPC komplex a hibához vonzza és kihorgonyozza a transzkripciós faktor II H (TFIIH) komplexet. Az XPC a TFIIH komplex p62 alegységével lép kapcsolatba, annak PH (pleckstrin homology) doménjén keresztül ${ }^{53,54}$. Ezt követően az XPC-nek el kell távolodnia a DNS-röl, hogy helyet biztosítson a NER további lépéseihez szükséges fehérjék kötődéséhez. Az XPC disszociációját a DNS-ről a VCP/p97 ubiquitin szelektív szegregáz szabályozza, mely arról ismeretes, hogy a megkötött fehérjéket a 26S proteoszómához szállítja, hogy ott degradálódjanak ${ }^{55}$. Azonban még nem született arról konszenzus, hogy az XPC is lebomlik-e ilyen esetekben, vagy csak cirkulál a DNS körül, arra „várva”, hogy újra részt vegyen a hibafelismerésben ${ }^{43,56}$ (2. b ábra). A további lépések, vagyis a hiba meglétének igazolása és javítása a TC-NER és GG-NER közös szakaszához tartoznak. A GG-NER hibajavító útvonal sematikus ábrázolása látható a

\section{2. a és b ábrán.}

\subsubsection{Transzkripció kapcsolt nukleotid kivágó hibajavítás (TC-NER)}

A transzkripció kapcsolt nukleotid hibajavítást először Hanawalt és munkatársai írták le ${ }^{57,58}$. A TC-NER esetében a hibafelismerés egy indirekt folyamat, melynek során a hiba az elongáló RNS Polimeráz II (Pol II) elakadásához vezet, mely aktiválja a hibajavító folyamatokat. A transzkripció alatt a Pol II-vel tranziensen kölcsönhat a CSB (Cockayneszindróma B fehérje), valamint az UVSSA (UV-stimulated scaffold protein A) fehérje. A transzkrició folyamán a Pol II megállhat a promoter proximális pausing során (transzkripció iniciáció során bekövetkező Pol II komplex leállás), valamint a DNS szerkezetét nagy mértékben befolyásoló hiba hatására is. Ekkor a CSB fehérje, mely a Pol II upstream oldalán helyezkedik el, meghajlítja a DNS-t, létrehozva egy $80^{\circ}$-os hajlásszöget, majd a 3'-5' ATPdependens transzlokáz aktivitása révén megpróbálja kihúzni a DNS-t a Pol II komplexből, 
ezzel előre mozdítva a transzkripciós komplexet a templát szálon, amelyet transzkripciós pausingnak nevezünk ${ }^{59}$. Azonban, a sikertelen a „forward” transzlokáció, a CSB fehérjének jelzés értékü, mely azt jelenti, hogy egy DNS szerkezetét nagy mértékben befolyásoló hiba található a templát szálon. Ezen jelzés hatására erősebb kötés alakul ki a Pol II és a CSB között, amely aktiválja a TC-NER hibajavítást. A folyamat első lépéseként a CSA fehérje a DNS károsodáshoz lokalizálódik (Cockayne-szindróma A fehérje), mely szükséges a TCNER további faktorainak hibához való kötődéséhez ${ }^{60}$. A következő lépésben az UVSSA a hibához vonzza az USP7 (Ubiquitin specific-processing protease 7) fehérjét, majd a DDB1CRL-komplex kötődése is megtörténik (amely a DDB1 linker proteinből, továbbá a Cul4A és a Roc1 fehérjékből áll) ${ }^{61}$. Így összeáll a nagyobb, $\mathrm{CRL}^{\mathrm{CSA}}$ komplex, mely ubiqutin ligáz

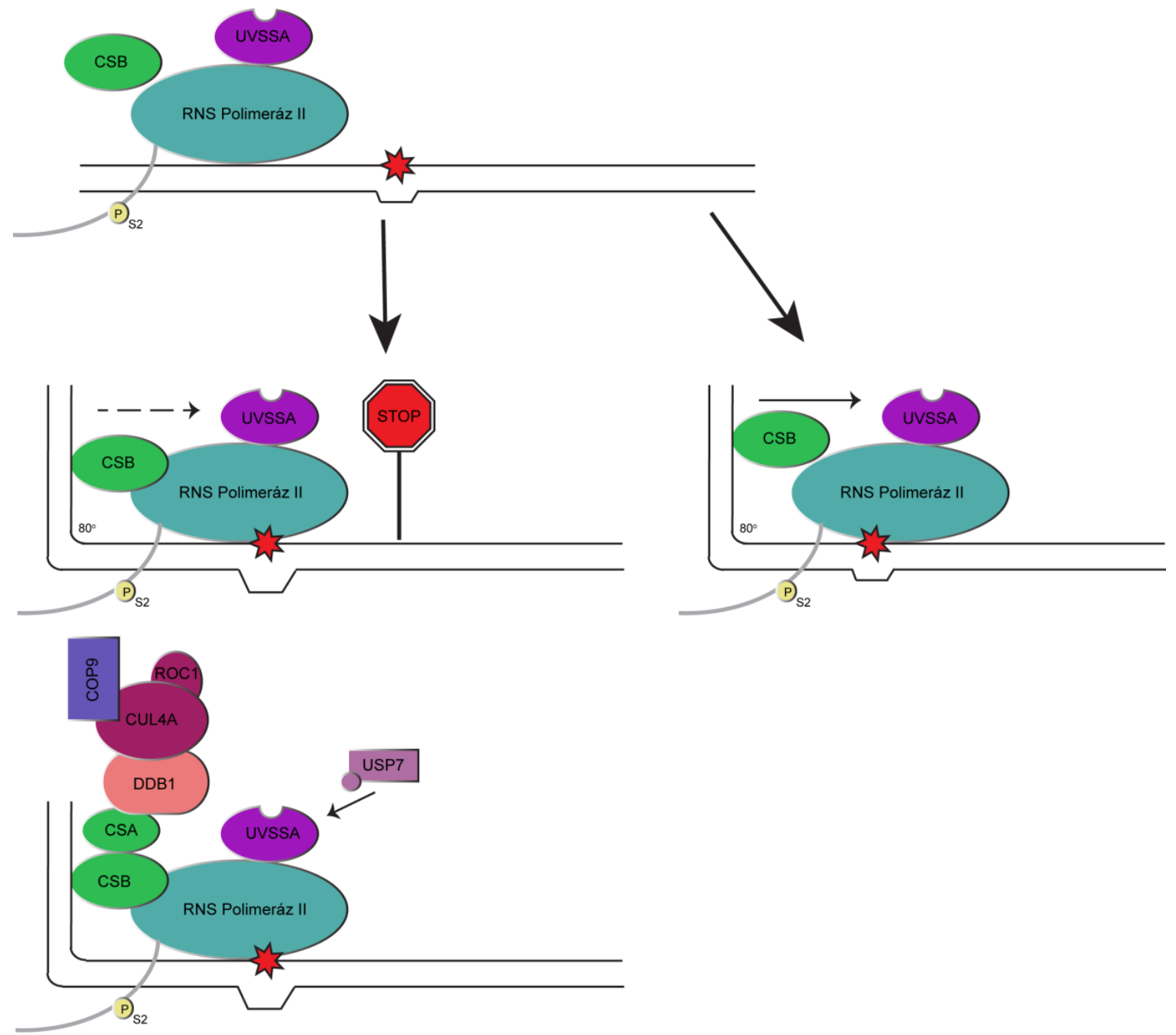

3. a ábra: A transzkripció kapcsolt nukleotid kivágó (TC-NER) hibajavító útvonal hibafelismerési szakasza. A CSB fehérje központi szerepet tölt be a Pol II megállását követő javítóútvonal aktiválásában. 
funkcióval rendelkezik, és saját magát, valamint környezetét is szabályozza a hibafelismerés folyamatában.

Ezen komplex szabályozása hasonló a GG-NER-ben tapasztalt CRL ${ }^{\text {DDB2 }}$ komplexéhez, vagyis alapesetben a COP9 fehérje által inaktivált állapotban található (3. a ábra). A komplex hibához történő kötődésekor, a COP9 protein disszociál a komplexről, amit a NEDD8 neddilál, ezzel aktiválva azt. Az aktív komplex számos fehérje ubiquitilációját végzi, többek között a Pol II-ét, azonban ezen ubiquitiláció nem jár a Pol II degradációjával.
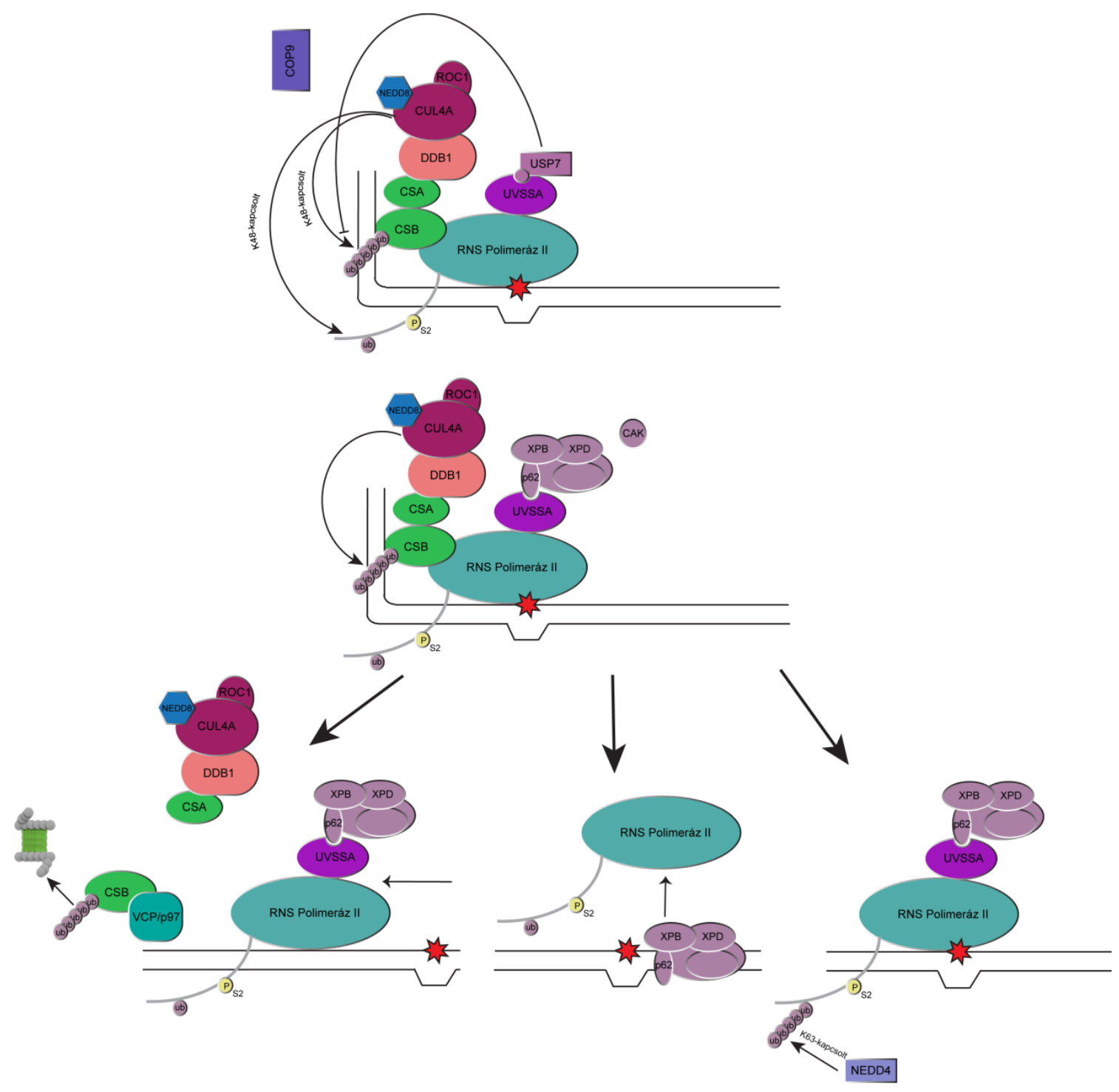

3. b ábra: A transzkripció kapcsolt nukleotid kivágó (TC-NER) hibajavító útvonal hibafelismerési és Pol II sorsának meghatározó szakasza. A CRL ${ }^{\mathrm{CSA}}$ komplex központi szerepet tölt be a Pol II megállását követő javítoútvonal szabályzásában. A Pol II eltávolításának a hibát hordozó DNS szálról 3 módja ismert. 
A CRL ${ }^{\mathrm{CSA}}$ komplex ubiquitilálja a CSB fehérjét is, ezzel proteoszómális lebontásra kijelölve azt. Azonban a CSB ubiquitilációs állapotát az UVSSA által a hibához vonzott USP7 deubiquitiláz is befolyásolja. Míg az USP7 a DNS károsodásnál lokalizálódik, addig a CSB nem ubiquitilálódik, ezáltal nem degradálódik. Mikor az USP7 deubiquitiláz disszociál a hibás DNS szakaszról, akkor az ubiquitilációs gátlás megszünik, így a CSB poliubiquitilálódik, majd lebontja a proteoszóma. Az USP7 helyére a TFIIH komplex p62 alegységén keresztül kapcsolódik az UVSSA protein centrális felszínén lévő rövid, erősen konzervált, savas karakterü aminosav oldalláncokkal rendelkező régiójához ${ }^{62}$. A TFIIH
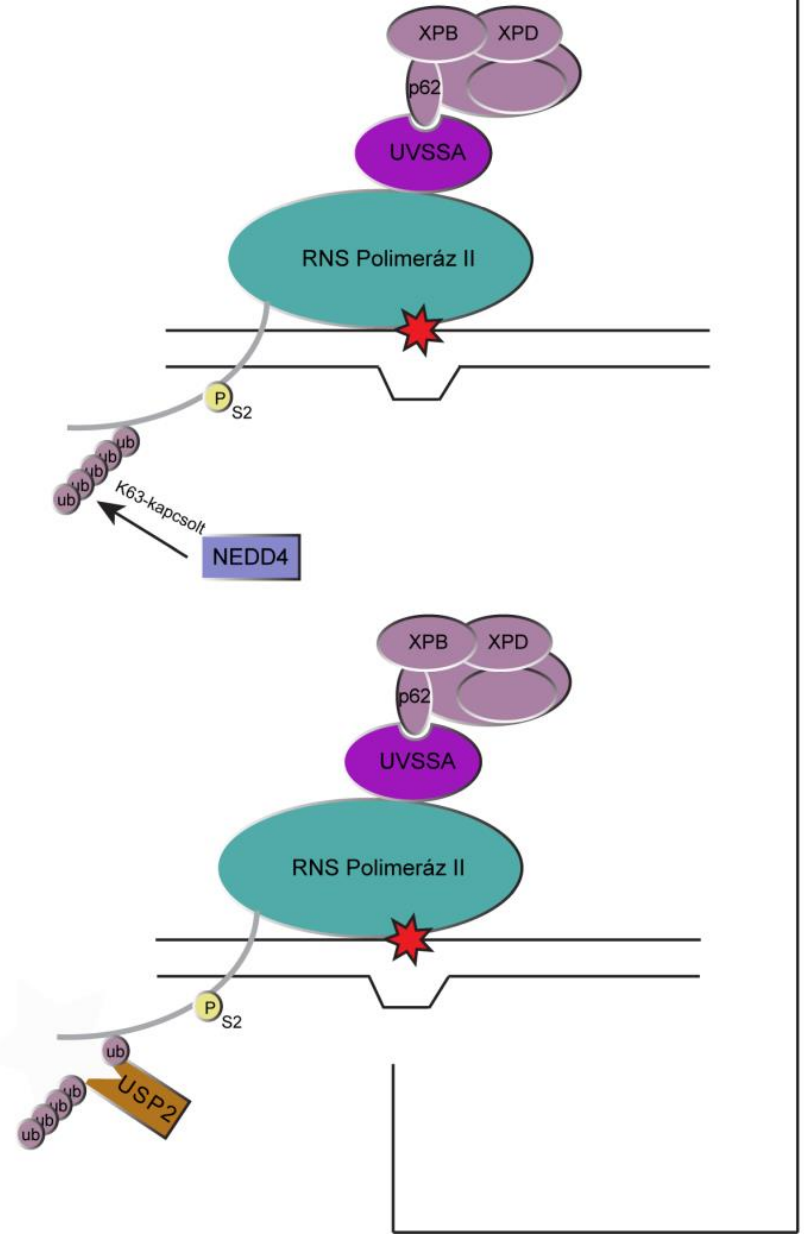

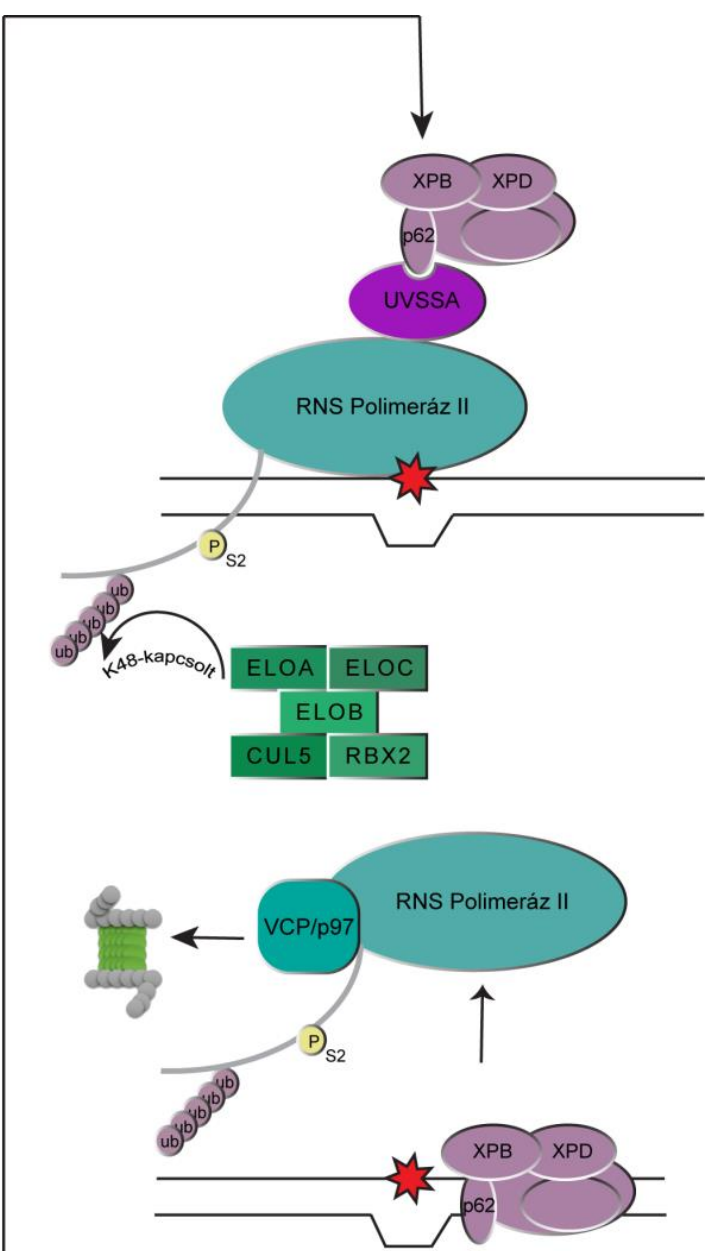

3. c ábra: A transzkripció kapcsolt nukleotid kivágó (TC-NER) hibajavító útvonal hibafelismerési szakaszának második fele vagyis a Pol II ubiquitilációját követő degradációja. A Pol II 26S proteoszóma általi lebontása egy több lépéses, számos fehérje által szabályozott folyamat, melyben az ubiquitin ligázok és ubiquitilázok játszanak központi szerepet. 
faktor számos funkciót lát el a NER folyamán, többek között a Pol II elmozdításában is szerepet játszik.

A Pol II a hibánál áll meg a DNS-en, így fizikálisan letakarva azt, valamint a környező 35 nukleotidot, ezzel gátolva a hibajavító fehérjék DNS-hez való hozzáférését ${ }^{63}$. Ennek feloldására a DNS hibajavító rendszer 3 módszert alkalmazhat: (I) a Pol II visszalép, úgynevezett „backtracking” következik be, valószínüleg a TFIIH komplex segítségével, mely folyamatot támogatja: a CSB protein i) eltávolítása, ii) degradációja vagy iii) ATPáz aktivitásának gátlása ${ }^{59,64,65}$. A folyamat során a már megszintetizált pre-mRNS is megmarad ${ }^{66}$. (II) Az is előfordulhat, hogy a DNS károsodás helyéről a Pol II is disszociál ${ }^{17}$. Ha ezek egyike sem megoldható, (III) akkor számos komplex segítségével a Pol II ubiquitilálódik, majd a 26S proteoszóma által lebomlik ${ }^{67,68}$ (3. b ábra). Ez egy több lépéses, számos fehérje által szabályozott folyamat. Elsőként a Pol II legnagyobb alegysége az RPB1 fehérje K-63 oldalláncon keresztül mono- vagy poliubiquitilálódik a NEDD4 fehérje által, mely egy E3 ubiquitin ligáz. Ezt követően az ubiqutin láncot az USP2 deubiqutiláz enzim lerövidíti egy ubiquitin molekulára ${ }^{36}$. Ezen K-63 monoubiquitin jelet ismeri fel egy másik E3 ubiquitin ligáz komplex, mely tagjai az Elongin A (ELOA), ELOB, ELOC, CUL5, RBX2 (RING-box protein 2). A felismerés után K-48 oldalláncon keresztül poliubiqitilálják az RPB1 fehérjét, melyet ezáltal a VCP/p97 a proteoszómához szállítja, ahol lebomlik ${ }^{67}$ (3. c ábra).

Miután a Pol II eltávolítása vagy elmozgatása (backtracking) eredményeként a hibás DNS szakasz hozzáférhetővé válik, a hibához kötődik az XPA és folytatódik a hibajavítás. A további lépések már TC-NER és GG-NER közös szakaszához tartoznak. A TC-NER sematikus ábrázolása a 3. a, b és c ábrán látható.

\subsubsection{A transzkripció kapcsolt és a teljes genomra kiterjedő nukleotid kivágó hibajavítás}

\section{közös lépései}

Az XPC aktivációja, valamint a Pol II hibától való eltávolítása után, a GG-NER és a TCNER egy közös hibajavító útvonalban egyesül, melynek első lépéseként a TFIIH és az XPA a DNS károsodás helyéhez kötődik. A következő lépés a károsodott DNS körüli kettős szálú DNS szakasz nagyobb mértékü felnyitása, valamint a DNS hiba meglétének ellenőrzése. Erre azért van szükség, hogy ténylegesen csak azokon a DNS szakaszokon történjen meg a javítás, ahol DNS hiba található. A TFIIH komplex XPB (ERCC3 gén által kódolt fehérje), valamit XPD (ERCC2 gén által kódolt fehérje) proteinjeinek ellentétes polaritású helikáz aktivitása révén a DNS két szála felnyílik a lézió környékén ${ }^{69-71}$. Ezzel párhuzamosan az 
XPD az XPA fehérje segítségével ellenőrzi a hiba jelenlétét a DNS-en 5'-3' helikáz aktivitása révén ${ }^{72,73}$. Kimutatták, hogy az archeákban található XPD ortológ fehérje $\operatorname{ArcH}$ és Fe-S domainjei egy csatornát képeznek az ssDNS köré, melyen csak a hibátlan DNS szál tud áthaladni ${ }^{74-78}$. Ha az XPD a DNS-en nem érzékel hibát, vagyis megakadás nélkül képes
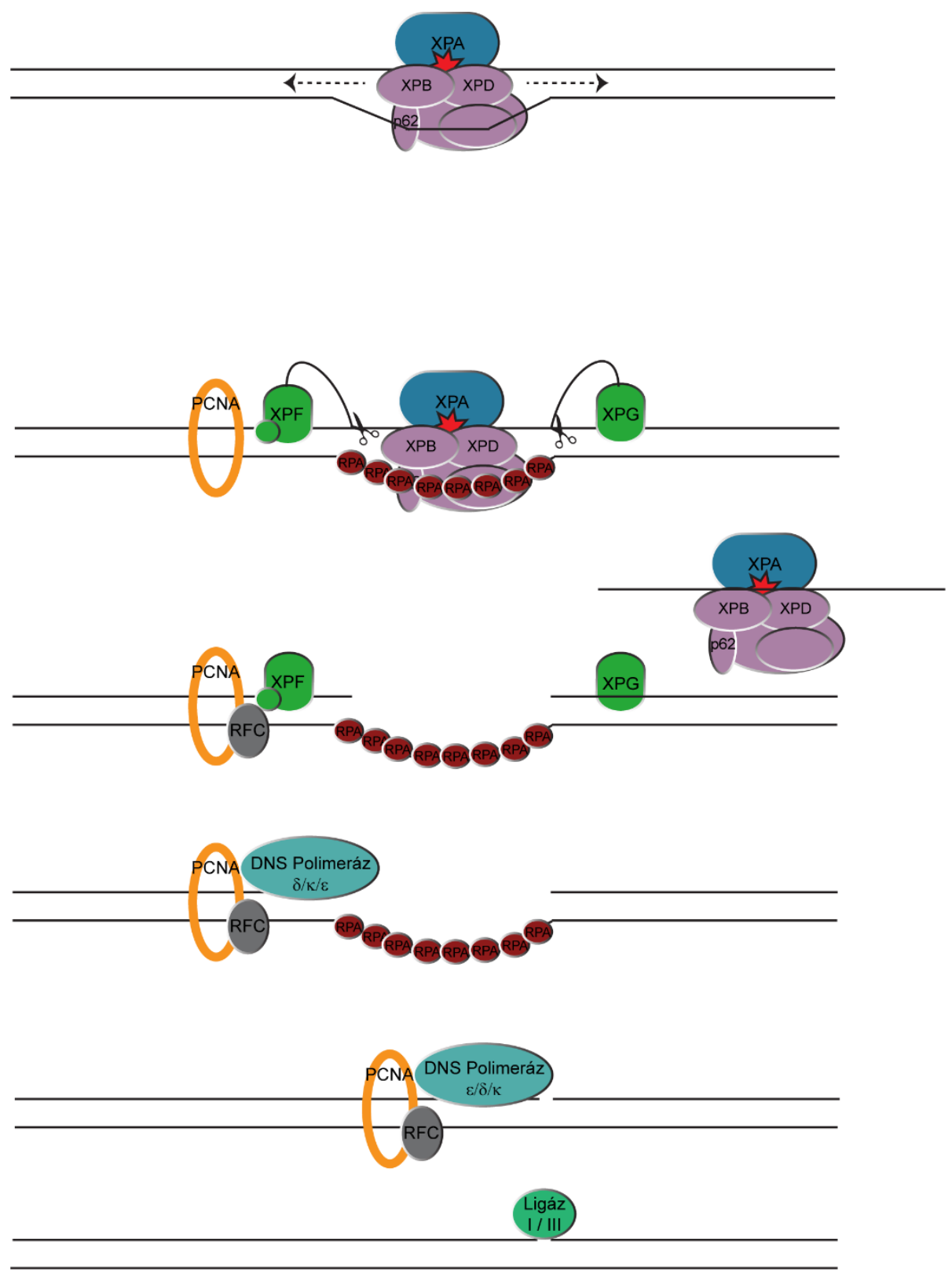

4. ábra: A transzkripció kapcsolt és a teljes genomra kiterjedő nukleotid kivágó hibajavítás közös lépéseinek sematikus ábrázolása. Ebben a szakaszban az XPB és XPD helikázok kiterjesztik a DNS buborékot a hiba körül, miután az XPD igazolta a hiba jelenlétét. Végül egy 22-30 nukleotidnyi DNS szakaszt vágnak ki az XPF-ERCC1 és XPG endonukleázok, melyet a DNS Polimeráz feltölt. 
az ssDNS szálon áthaladni, akkor a teljes hibajavító komplex disszociál a DNS-ről, ezzel megakadályozva a hibajavító útvonal későbbi lépéseinek aktivációját.

Ha a DNS károsodás jelen van és a DNS buborék kiterjedt, a DNS hibával szembeni ssDNS szálat RPA (Replication protein A) fehérjék burkolják be, ezzel védve a sérülékeny DNS szálat. Az XPA fehérje az RPA proteinek segítségével a hibához vonzza az XPF-ERCC1 heterodimert, melyet az RPA fehérjék pozícionálnak a DNS szálon a hibától 5' irányba, valamint az XPG (ERCC5 gén által kódolt fehérje) fehérjét, melyet a hibától 3' irányba vezérelnek ${ }^{79}$. Az XPF-ERCC1 endonukleáz aktivitása révén 5' irányban bemetszi a DNS-t, míg az XPG pedig a 3' bevágásért felelős, ezzel kimetszve egy 22-30 nukleotid hosszúságú ssDNS szakaszt, mely tartalmazza a DNS léziót ${ }^{80,81}$. Az 5 ' végi bemetszést követően, vagy a hibás szál teljes eltávolítása után, a PCNA (Proliferating cell nuclear antigen) a DNS-hez kötődik, majd magához vonzza az RFC (Replication factor C) proteint, valamint a DNS feltöltéséhez szükséges egyéb faktorokat ${ }^{17,82}$. Replikálódó sejtekben a DNS Polimeráz $\varepsilon$, a DNS ligáz 1-gyel müködik együtt a folyamatban, míg nem replikálódó sejtek esetében a szerepüket a DNS Polimeráz $\delta$ vagy k, valamint az XRCC1-DNS ligáz 3 látja el ${ }^{17,83}$.

A GG-NER és a TC-NER kezdeti lépéseit követő egyesült hibajavító útvonal sematikus ábrázolását a 4. ábra szemlélteti.

\subsection{Az UV hatására kialakuló tumoros folyamatok biokémiai háttere}

Az UV sugárzás hatására kialakuló DNS hibákat elsődlegesen a NER fehérjéi ismerik fel és javítják ki. Azonban, mint minden rendszerben, ebben is kialakulhatnak defektusok. A NER útvonalban résztvevő fehérjéket kódoló gének mutáció miatt kialakuló betegségek tünetegyüttesei igen széles skálán mozognak, a tumorok kialakulásának megnövekedett hajlamától egészen az idegrendszeri fejlődési zavarokig. A tünetek súlyosságát, illetve a betegség fajtáját befolyásolja, hogy a hibás faktor a NER útvonal melyik szakaszában látja el feladatát normál körülmények között.

A GG-NER-ben résztvevő faktorok kiesésével, mint például az XPC az ún. Xeroderma pigmentosum betegség alakul ki. Ezen betegségben szenvedő páciensek jellemzően érzékenyek az UV sugárzásra, hipo- vagy hiperpigmentáció figyelhető meg a börükön, továbbá igen magas hajlamuk van különböző bőrtumorokra ${ }^{84}$. A különböző belső szervrendszeri tumorok kialakulása is gyakrabban előfordul ezen páciensek körében, hisz a 
GG-NER kiesésével az endogén károsító ágensek, mint például a reaktív oxigéngyökök miatt kialakult DNS károsodások javítása is elmarad ${ }^{85,86}$.

A TC-NER útvonalban szerepet játszó fehérjék kiesésével kialakuló betegségek súlyosabb tünetekkel járnak. Ilyen esetekben a Cockayne-szindrómát és a COFS betegséget (Cerebrooculo- facio-skeletal syndrome) figyelték meg. Mindkét szindrómára jellemző a progeroid fenotípus, vagyis a korai öregedés, továbbá a microcephalia, diszmielinizáció miatt kialakuló mentális retardáció, retina degeneráció, cachexia, azaz kóros lesoványodás, valamint fényérzékenység is. A várható élettartam igen rövid, Cockayne-szindrómánál 12, míg COFS betegség esetében 2 év ${ }^{87}$.

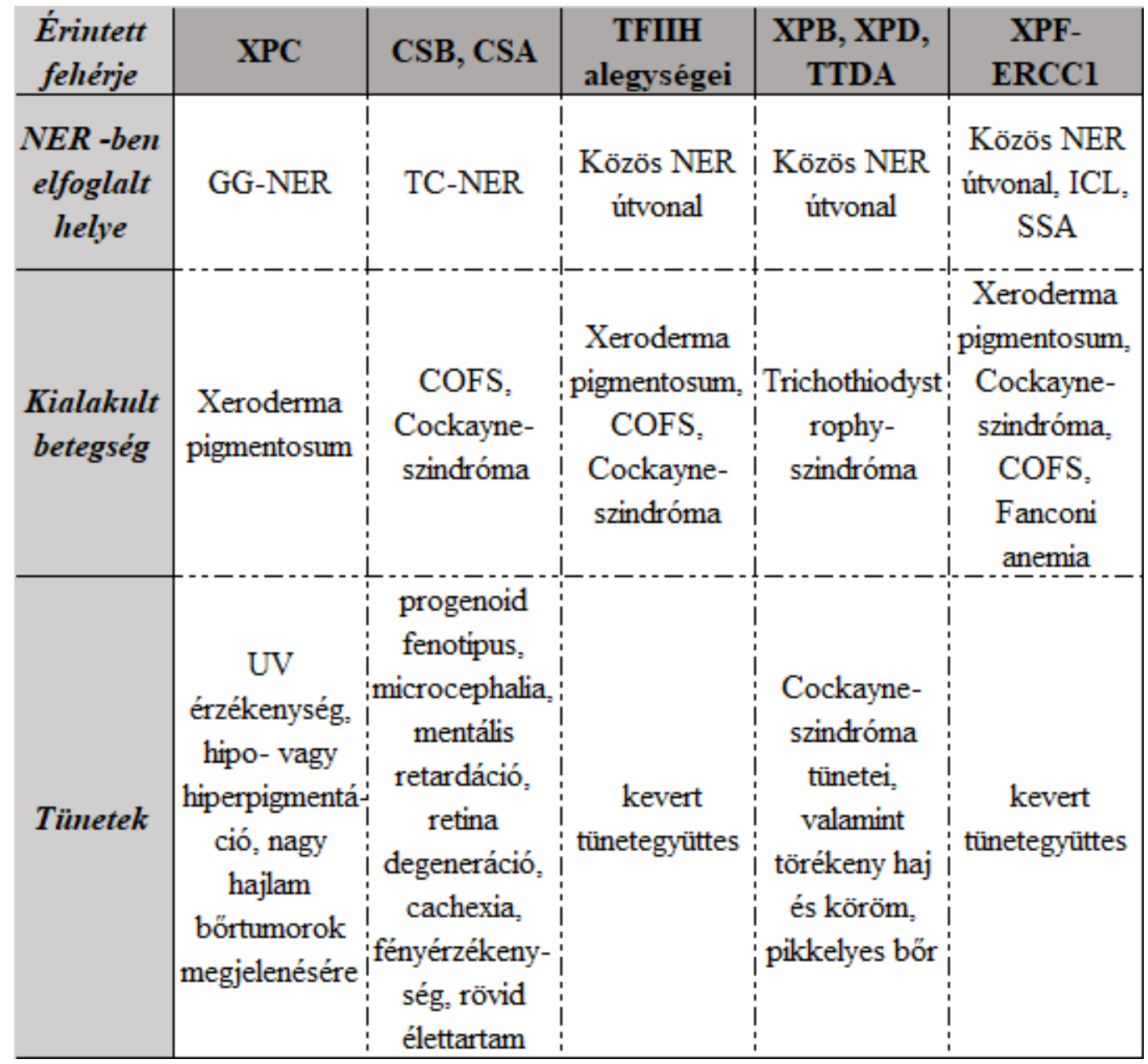

\section{5. ábra: A NER hibajavításban szerepet játszó fehérjék mutációja következtében kialakuló betegségek és szindrómák összefoglaló táblázata.}

A NER útvonal közös szakaszában résztvevő faktorok kiesésével, igen változatos kórképek jöhetnek létre. A TFIIH komplex valamely fehérjéjének nem megfelelő müködése esetén 
megfigyeltek Xeroderma Pigmentosum, Cockayne-szindóma, vagy COFS betegség kialakulását is, vagy ezen megbetegedések tüneteinek kevert változatát is. Az XPB, XPD, vagy a TTDA gének specifikus mutációja kiválthat Trichothiodystrophy szindrómát, mely tünetei a Cockayne-szindrómára hasonlítanak és jellemző az ebben szenvedő betegekre a törékeny haj és köröm, továbbá a pikkelyes bőr ${ }^{88}$. Az eltérö tünetek oka, hogy ezekben a betegekben a TFIIH stabilitása és müködése nem megfelelö, ezáltal a haj, bőr és köröm sejtjeinek terminális differenciációja kárt szenved ${ }^{89-91}$.

XPF-ERCC1 komplexet alkotó fehérjéket kódoló DNS szakaszok mutációi összetett tünetegyüttest eredményeznek ${ }^{92}$. Ennek oka, hogy a fehérje nem csak a NER folyamatában vesz részt, hanem endonukleáz aktivitása az ICL (interstrand crosslink repair), valamint az SSA (single-strand anneling) hibajavításban is szerepet játszik. Attól függően, hogy adott páciensben milyen funkció veszik el, a tünetek megegyezhetnek a Xeroderma pigmentosum, a Cockayne-szindróma, a COFS betegség, valamint a Fanconi anémia szimptómáival is ${ }^{92-}$ 96.

Mindezen tünetekből látható, hogy egyetlen fehérje kiesése vagy megváltozott müködése igen jelentősen befolyásolhatja a nukleotid kivágó hibajavítást, ezáltal pedig a sejtek müködését, mely végső soron számos betegség, többek között a tumorok kialakulásához is vezethet. A NER hibajavításban szerepet játszó fehérjék mutációja következtében kialakuló betegségek és szindrómák összefoglaló táblázata az $\mathbf{5}$. ábrán látható.

\subsection{Bőr eredetű sejtekből kialakuló tumortípusok}

A bőr eredetü tumorok közé sorolható minden olyan tumortípus, mely a bőr egy meghatározott típusú sejtjéből indul ki. A rosszindulatú bőrtumorok két nagy csoportra bonthatók: melanoma és nem-melanoma típusú tumorokra. A melanoma a bőr pigmentsejtjeiből kialakuló rosszindulatú daganat, mely legtöbbször az alsó végtagokon vagy a törzsön jelentkezik ${ }^{97}$. Azonban nagyon ritkán, de előfordul, hogy a melanoma a szájüreg, anus, vagina, kötőhártya vagy a retina sejtjeiből is kialakul ${ }^{98}$. Évente körülbelül 76.000 új esetet diagnosztizálnak, valamint a betegség okán az USA-ban 10.000 halálesetet jegyeznek. A bőrrákok közül a melanomák csak az esetek 4\%-át teszik ki, de a legnagyobb morbiditású és mortalitású tumortípus. Növekvő incidenciája mellett a betegség egyre fiatalabb korban jelentkezik ${ }^{99}$. Megjelenésére jellemző, hogy az anyajegyek nagysága, 
alakja, színe megváltozik, széle szabálytalan lesz, számos esetben viszket és vérzik ${ }^{100}$. Feltűnő a nagyfokú színvariabilitás az elváltozáson belül. Különböző árnyalatú barna, szürke, fekete, kék, rózsaszín és akár fehér területek is észlelhetők ${ }^{97}$.

A melanomák többsége hosszú ideig csak oldalirányba, cirkulárisan terjed, melyet horizontális növekedési fázisnak hívnak. Ezen fázisban a melanoma sejtek csak az epidermiszben, vagy az epidermisz-dermisz határán képesek osztódni. Esetlegesen néhány tumorsejt kimutatható a papilláris dermiszben, de bizonyos szövettani jelek szerint még nem képesek a származási helyükön kívül (epidermisz) növekedni. Mikor a plakkban csomó jelenik meg, a melanoma átlép az úgynevezett vertikális növekedési fázisba. Ilyenkor a tumorsejtek már a dermisz mélyebb rétegeiben is megjelennek és osztódnak. Klinikai szempontból a melanomák ilyenkor már egyértelmü göbként mutatkoznak. A következő fázis a metasztázis képzés, melynek során az eredeti daganat mellett, de azzal össze nem függő tumorgöbök, szatelliták jelennek meg ${ }^{97}$.

A melanoma három leggyakoribb szövettani altípusa: (I) Cutan, mely a leggyakoribb formája. A többségét a betegek korai stádiumban fedezik fel. A betegség előrehaladott állapotában megnagyobbodott nyirokcsomók, bőrcsomók tüdő-, máj-, bél-, mesenteriumtünetek vagy agyi metasztázis tünetei figyelhetők meg. (II) Az uvealis melanoma az írisz, a sugártest vagy az érhártya melanocitáiból eredő daganat, melyet általában véletlenül, vagy a beteg látáspanaszai miatt fedeznek fel. (III) A mucosalis a nyálkahártya-felületek melanocitáiból eredő forma, melyre a nyálkahártyavérzés jellemző ${ }^{99}$.

A malanoma fizikai vizsgálatára az ún. ABCDE pontrendszer jellemző: A: asszimetria, B: szabálytalan szélek (borders), C: változatos színek (color), D: a tumor átmérőjének nagysága (diameter), valamint E: a változó kép (evolution) ${ }^{99}$.

A melanoma stádium besorolásánál a következő paramétereket veszik figyelembe:

(I) a tumor vastagsága $(\mathrm{mm})$

(II) a primer tumor fekélyesedésre való hajlama

(III) nyirokcsomóstátus patológiai jellemzése (érintett nyirokcsomók száma és mérete)

(IV) metasztázis megléte és helyének jellemzése ${ }^{99}$ 
Azonban Oláh Judit és Dobozy Attila Magyar Onkológia 2003-as folyóiratában megjelent értekezése szerint a következő pontokkal kiegészítve kell a melanomák stádiumát meghatározni:

(V) örszemnyirokcsomó-biopszia segítségével nyirokcsomóstátusz patológiai felmérése

(VI) in transit/satellita áttét meghatározása

(VII) szérum laktátdehidrogenáz szintjének meghatározása ${ }^{101}$.

A melanoma stádiumbeosztását a 6. ábra szemlélteti ${ }^{99}$

\begin{tabular}{|c|c|c|c|}
\hline \multicolumn{3}{|c|}{ A melanoma AJCC szerinti stádiumbesorolása } \\
\hline $\begin{array}{c}\text { Stádium } \\
\text { (diagnózis } \\
\text { megállapítás akor) }\end{array}$ & Tumor (T) & Nyirokcsomó (N) & Metasztázis (M) \\
\hline IA/B & $\begin{array}{c}\leq 1 \mathrm{~mm} \text { vagy 1,01- } \\
\text { mm fekély nélkül }\end{array}$ & Nincs & Nincs \\
\hline IIA-C (I/II=80- & $\begin{array}{c}1,01-22 \mathrm{~mm} \\
\text { fekéllyel, vagy } \\
\text { bármilyen, ha } \geq \\
2,01 \mathrm{~mm}\end{array}$ & Nincs & Nincs \\
IIIA-C (10-15\%) & Bármilyen T & $\begin{array}{c}\text { Regionális } \\
\text { nyirokcsomó vagy } \\
\text { tranzit metasztázis }\end{array}$ & Nincs \\
\hline IV (1A-1C) (5\%) & Bármilyen T & Bármilyen N & Távoli metasztázis \\
\hline
\end{tabular}

\section{6. ábra: A melanoma stádiumbesorolását szemléltető összefoglaló táblázata.}

A táblázatban a különböző stádiumú melanoma tumor-, nyirokcsomó- és metasztázis állapota szerepel. Az ábra az Onkológia kézikönyv (Alexander E. Drilon, Michael A. Postow, 2016.) alapján készült.

A nem-melanoma típusú börtumorok (NMSC- non-melanoma skin cancer) közül a két legjelentősebb és leggyakoribb a bazális sejtes karcinóma (BCC- basal cell carcinoma), 
valamint az elszarusodó laphámrák (SCC-squamous cell carcinoma) ${ }^{13,14}$. Az SCC egy igen invazív tumortípus, mely általában a környező szöveteket is roncsolja. Gyakran alakul ki metasztázis, azonban, ha korai stádiumban diagnosztizálják, a páciensek túlélési esélyei javulnak. BCC tumorokra jellemző, hogy lassan növekednek, és igen ritkán halálos kimenetelüek. Késői diagnózis esetében képesek a környező szöveteket és csontokat is roncsolni, azonban távoli metasztázis igen ritkán alakul ki ennél a tumortípusnál ${ }^{102}$. A bőr típusú tumorok felosztásáról és a bőr rétegeiben történő elhelyezkedéséről összefoglaló grafika a 7. ábrán látható.

A nem-melanoma típusú tumorok, melyek a bőrtumorok előfordulásának 95\%-át teszik ki, a humán rosszindulatú daganatok leggyakoribb típusai ${ }^{103}$. Az NMSC tumoros esetek száma 1960 óta évröl-évre nő, azonban a halálozási ráta szerencsére csökken ${ }^{102}$.

Az NMSC tumorok kialakulásának legfőbb oka a gyakori, vagy hosszú idejü UV sugárzásnak való kitettség. Ebből következik, hogy az NMSC daganatok föképp a napnak kitett bőrfelületeken jelennek meg, mint például az arc, nyak, a törzs felső része vagy a végtagok ${ }^{104,105}$. Kutatások eredményeként kapcsolatot találtak a tumorok kialakulása és az immunszupresszió, valamint a fehér börtónus között is ${ }^{102}$. Továbbá kimutatták, hogy a transzmembrán receptor PTCH1 (patched homolog 1) gén, valamint az azzal kölcsönható G-protein-kapcsolt receptor, az SMO (smoothened homolog) génjében bekövetkező mutáció következtében a sonic hedgehog szignalizációs útvonal állandó aktivációja figyelhető meg, mely következtében az epidermális bazális sejtek korlátlan osztódása tapasztalható ${ }^{106}$. 


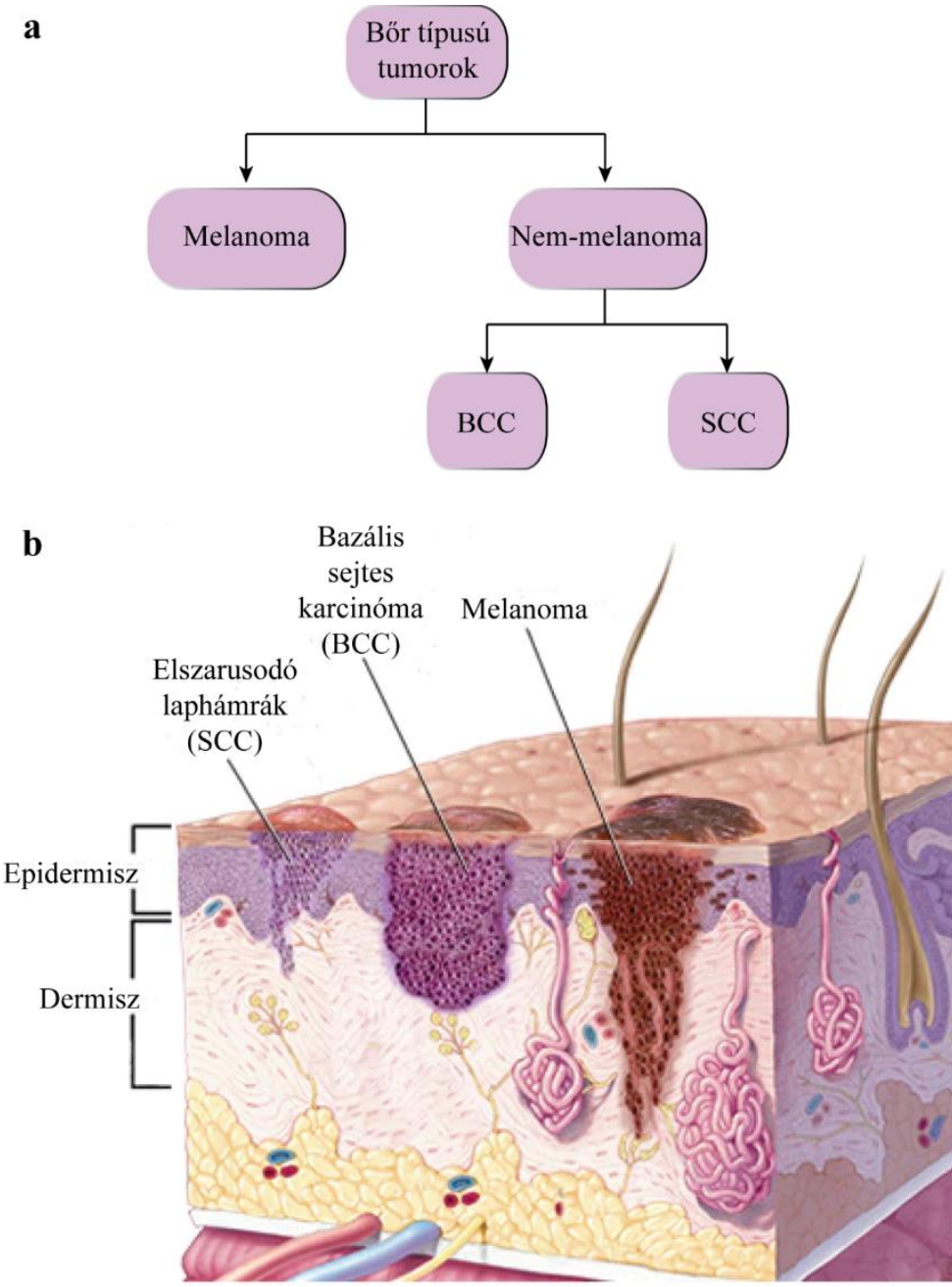

7. ábra: Bőr típusú tumorok felosztása és elhelyezkedésük a bőr rétegeiben:
(a) A bőr típusú tumorok felosztása sejt eredetük szerint. (b) A bőr típusú tumorok
elhelyezkedésének sematikus ábrázolása a bőr különböző rétegeiben. Az ábra a Mayo
Clinic BCC összefoglaló oldala alapján készült.

\subsection{A BCC tumorok jellemzése}

A bazális sejtes karcinóma (BCC) egy rosszindulatú bőr eredetủ daganatos elváltozás, mely az epidermisz alsó, bazális rétegéből származó sejtjeiből alakul ki. Általában a középkorú, vagy idősebb páciensek fénynek kitett bőrfelületein alakul ki. Az esetek 10-13\%-ában tapasztalható a fényvédett bőrterületeken való megjelenése. A teljes esetszám 20-30\%-át az orron megjelenő BCC-k teszik ki. A BCC tumorok megjelenésére általánosan jellemző a bőrszínű vagy áttetsző vöröses papula, illetve csomó formájú képlet, mely szélei lekerekedettek, középen kifekélyesedés, vérzés, pörkképződés látható ${ }^{97}$. A 
nyálkahártyafelszínek, melyekben adnexumok (függelékek) nem fordulnak elö (pl. nyelv, ajak, cervix), soha nem szerepelnek primert kiindulási helyeként. A tumorok némelyike változó mértékben pigmentált. Az elhanyagolt léziók lokálisan penetrálhatnak, destruktívvá válhatnak, de szokványos lefolyásuk lassú, ami hónapokon, vagy akár éveken át is tarthat ${ }^{98}$.

Szövettanilag a BCC-k kompakt, sötét kromatinnal bíró, orsó alakú sejtek invasiv csoportjaiból, kötegeiből állnak, melyek a metszés síkjában gyakran nincsennek összefüggésben sem a felszíni epidermális réteggel, sem az adnexumokkal ${ }^{98}$.

\begin{tabular}{|c|c|}
\hline \multicolumn{2}{|c|}{ A BCC stádiumbesorolása } \\
\hline Stádium & Carcinoma in situ \\
\hline I.stádium & Tumorméret $\leq 2 \mathrm{~cm}$ \\
\hline II.stádium & Tumorméret $>2 \mathrm{~cm}$ \\
\hline III.stádium & $\begin{array}{c}\text { A tumor ráterjed a mandidulára, maxillára, szemüregre vagy az os } \\
\text { temporaléra, de nincs nyirokcsomó érintettség, vagy bármely méretü| } \\
\text { tumor és azonos oldali nyirokcsomó-érintettség } \leq 3 \mathrm{~cm}\end{array}$ \\
\hline IV.stádium & $\begin{array}{c}\text { Azonos oldali nyirokcsomó-érintettség }>3 \mathrm{~cm}, \text { kétoldali vagy } \\
\text { ellenoldali nyirokcsomó-érintettség, többszörös azonos oldali } \\
\text { nyirokcsomó-érintettség, nyirokcsomó } \geq 6 \mathrm{~cm}, \text { távoli metasztázis }\end{array}$ \\
\hline
\end{tabular}

\section{8. ábra: A BCC stádiumbesorolását szemléltető összefoglaló táblázata.}

A táblázatban a különböző stádiumú $\mathrm{BCC}$ tumorra jellemző paraméterek szerepelnek. Az ábra az Onkológia kézikönyv (Alexander E. Drilon, Michael A. Postow, 2016.) alapján készült.

A bőrtumorok közül a BCC a legnagyobb esetszámmal rendelkező tumortípus a világon ${ }^{107}$. Az Egyesült Államok lakosai között a nem melanoma típusú bőrrákok a leggyakoribb carcinomák, melyek közül a BCC ötször gyakoribb, mint a csoportba tartozó SCC ${ }^{99}$. A BCC tumorokat klinikai és hisztológiai tüneteik alapján 5 altípusba sorolják nevezetesen: (I) noduláris, vagy csomós, mely a leggyakoribb változata. A daganataira a gyöngyház vagy 
viaszos kupolaszerü dudorok jellemzők, számos esetben látható véredényekkel és centrális fekélyesedéssel, (II) a szuperficiális vagy multicentrikus BCC-kre jellemző a lapos, erythemás plakkok, melyek rendszerint a törzsön jelennek meg. Anamnézisük esetében gyakori a beteg korábbi sugárkezelése vagy arzénexpozíciója. (III) A pigmentált BCC-re a barna, kemény vagy hegszerü károsodás jellemző. Mind a noduláris, mind a szuperficiális BCC lehet pigmentált, mely gyakoribb megjelenésü a sötétebb bőrü egyéneknél. (IV) A szklerotizáló vagy morpheaform BCC-re jellemző az atrophiás plakk, mely általában az arcon jelenik meg, leggyakrabban az orr vagy fül környékén. A tumorok gyakran a környező szövetekbe is áttörnek. Igen rossz prognózissal járó forma. (V) Az Ulcus terebrans extrém mértékben agresszív BCC, mely ráterjedhet a környező szövetekre. Gyakran halálos kimenetelü, azonban igen ritka betegség ${ }^{99,108}$. A BCC-k esetében a sebészeti kimetszés, a besugárzás vagy az adekvát kauterezés módszerét alkalmazzák a gyógyulás érdekében ${ }^{98}$.

Az NMSC tumorok, így a BCC-k esetében is bizonyították az UV sugárzás igen erős iniciáló hatását ${ }^{109}$. Ezen iniciáló hatás egyik bizonyítéka, hogy bőrtumorokban a p53 mutációja gyakran megfigyelhető, melyről bebizonyították, hogy az UV sugárzás kiváltotta CPD hibák is eredményezhetik ${ }^{110}$. További kockázati tényezők még a világos bőrszín, fiatalkori sugárexpozíció, tartós PUVA (psoralen+ UVA) expozíció vagy immunszupresszió. A BCC stádiumbeosztását a 8. ábra szemlélteti. ${ }^{99}$

\subsection{Serpinek: Szerin proteáz inhibítor (SP) fehérjecsalád}

A Serpinek az egyik legnagyobb és funkcionálisan legdiverzebb fehérjecsalád. Először Hunt és Dayhoff, valamint munkatársaik találtak hasonlóságot a csirke ovalbumin és két humán proteináz inhibítor, az antitrombin és az $\alpha 1$-proteináz inhibítor $\left(\alpha_{1} \mathrm{PI}\right)$ aminosav szekvenciája között, mely fehérjék lettek a később felfedezett fehérjecsalád első tagjai ${ }^{111}$. A Serpinek nevét Carrell és Travis alkotta meg a serine protease inhibitor szavak kezdőbetüiből, annak okán, hogy a család akkor ismert számos tagjának funkcióját takarta ezen név ${ }^{112}$. Mára a Serpinek körülbelül 1500 tagot számláló, doménszerkezetükben hasonló fehérjecsaládot alkotnak, melynek tagjai megtalálhatóak az emlősök és gerincesek mellett az állatvilág más osztályaiban is, valamint a növényeknél, vírusoknál, baktériumoknál és már az archeáknál is ${ }^{113-118}$. A Serpinek szerepét leírták már számos folyamatban, mint például a tumorgenezis, véralvadás, hormon transzport, immunrendszerben végbemenő változások, vagy akár a 
gyulladásos folyamatok során is ${ }^{119}$. A DNS szekvenciájuk és filogenetikai rokonságuk alapján a Serpineket 16 csoportba, úgynevezett kládokba osztották (A-P), melyekből az első 9 tagjai között szerepelnek a humán Serpinek (A-I) ${ }^{120}$. A humán Serpinek csoportjait a 9. ábra szemlélteti.

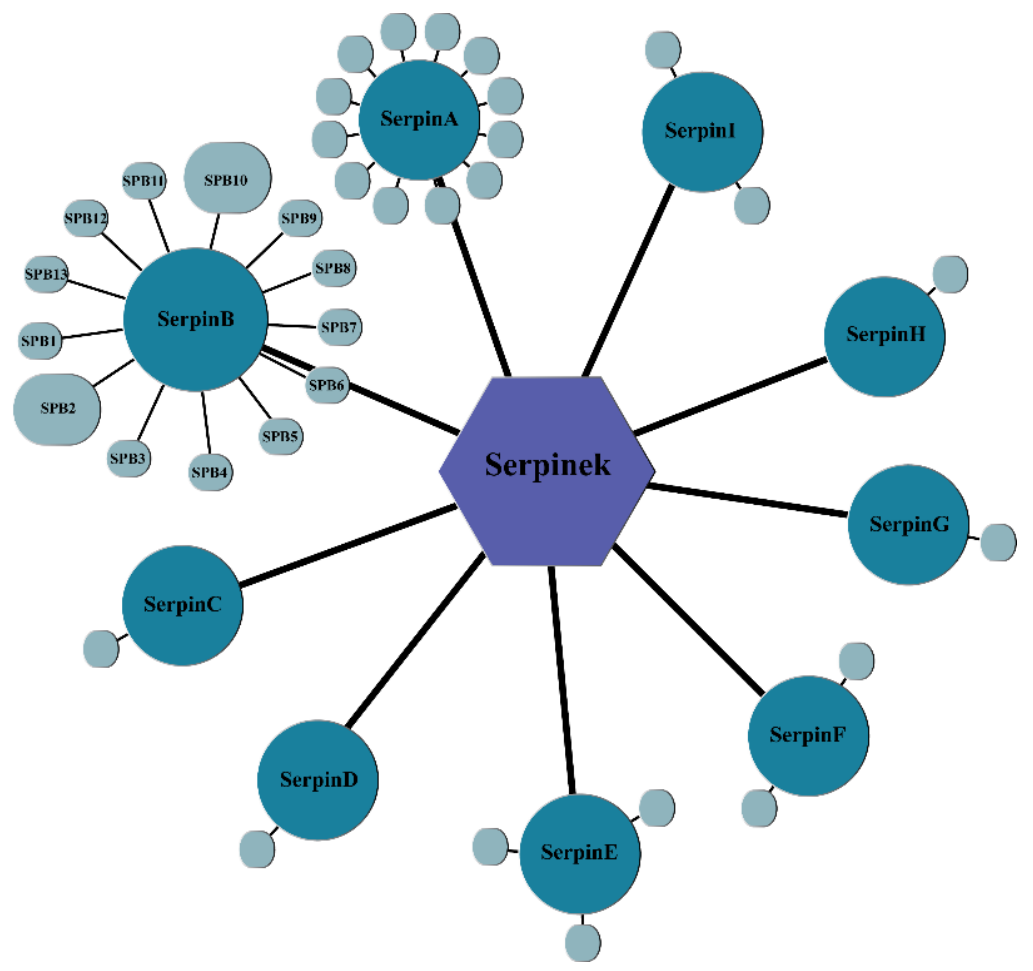

\section{9. ábra: Humán Serpinek csoportjainak sematikus ábrázolása:}

A humán Serpineket 9 csoportba oszthatjuk (A-I), melyek számos fehérjét foglalnak magukba. Az ábra Heit és munkatársai: Update of the human and mouse SERPIN gene superfamily cikke alapján készült.

A Serpinek általában 330-500 aminosavat tartalmazó, konzervált, jellegzetes harmadlagos struktúrával rendelkező fehérjék. Tartalmaznak három $\beta$-redőt (A, B és $\mathrm{C}$ ), 8 vagy több $\alpha$ hélixet, továbbá egy jellegzetes kihurkolódó szakaszt, az ún. RCL (reactive center loop) struktúrát, mely a proteázok aktív centrumával kapcsolódva gátolja azok fehérjebontó aktivitását, azon Serpinek esetében, melyek, mint inhibítorok müködnek ${ }^{120-122}$. A humán Serpinek közül eddig 34 gént és 5 pszeudogént írtak le ${ }^{119}$. Ezen Serpin fehérjéket kódoló gének többsége 2 kromoszómális lókuszban helyezkedik el, ami a 14. (nagyrészt az A klád tagjai) és a 18. kromoszómán (főleg a $\mathrm{B}$ klád tagjai) található, ami alátámasztja azon hipotézist, hogy a Serpinek gén-duplikációval (majd ezt követő differenciációval) jöttek létre 123,124. A kromoszómán egy lókuszban történő elhelyezkedésük ellenére ezen gének 
funkcionálisan igen különbözőek ${ }^{125}$. Továbbá az is elmondható ezen Serpin génekről, hogy jellegzetes exon-intron mintázattal rendelkeznek, mely szintén az azonos filogenetikai prekurzor génre utal ${ }^{126,127}$.

\subsubsection{SPB fehérjecsalád}

A SerpinB család (SPB) a legnagyobb humán géneket tartalmazó Serpin klád, mely 13 gént és egy pszeudogént foglal magába. Ezen gének a 6.kromoszóma rövid karján (6p25) és a 18. kromoszómán (18q21) helyezkednek el ${ }^{120,128}$. Akár a többi Serpinnél, az SPB család esetében is azt feltételezik, hogy tagjai egy „ősi” SerpinB génből jöttek létre, mely az emlősöknél duplikálódott és ezután két eltérő lókuszban lokalizálódott. Az evolúció folyamán ezen gének által kódolt fehérjék funkciójukban elváltak egymástól, így például számos proteázt képesek felismerni és gátolni, számos módszerrel, számos helyen (extracellulárisan, intracellulárisan a citoplazmában, vagy akár a sejtmagban), továbbá igen sokrétű funkcióval rendelkeznek ${ }^{129}$. A SerpinB-re két típusú génszerkezet jellemző: a 7 exon- 6 intron, illetve a 8 exon- 7 intron eloszlás, mely szintén alátámasztja a fentebb említett „közös ősgén eredet” hipotézist ${ }^{129}$.

A B klád tagjai föképp intracelluláris Serpinek ${ }^{130}$. Ezen kládba tartozó fehérjék általában rövidebb C- és N-terminális véggel rendelkeznek, mint az A klád tagjai, valamint hiányzik a szekréciót jelző szignál peptid szekvencia is róluk, továbbá jellemzőjük, hogy az utolsó elötti aminosavuk szerin ${ }^{120,131}$. Az SPB család nyolc tagjára jellemző egy egyedi interhelikális hurok, melyet CD-loop-nak nevez a szakirodalom, mely általában jelentős funkcionális doménje az adott Serpin fehérjének ${ }^{120,132}$. Az SPB család fehérjéi számos funkcióval rendelkeznek, többek között leírták már ezen család tagjait az immunválaszban, gyulladásos folyamatokban, nyáltermelésben, apoptózisban, a tumor metasztázis szabályozásában, valamint az autoimmunitás folyamatában is ${ }^{133,134}$.

\subsubsection{Az SPB2 fehérje jellemzése}

A SerpinB2 (SPB2) fehérjét először 1970-ben Uemura és munkatársai izolálták humán placentából ${ }^{135}$. Sokáig PAI-2 (Plasminogen activator inhibitor 2) néven jegyezték, mely azon extracelluláris funkciójára utalt, hogy plazminogén aktivátorokat képes gátolni, nevezetesen az uPA (urokinase plasminogen activator) és tPA (tissue plasminogen activator) 
enzimeket ${ }^{135-139}$. Az SPB2 fehérjét csak a terhesség alatt megjelenő inhibítornak vélték ${ }^{140}$. A későbbi kutatások rávilágítottak, hogy az SPB2 nagymértékủ expressziója figyelhető meg intracellulárisan lymphoma sejtekben is ${ }^{141,142}$. Azóta számos sejttípusban, mint például monocita, makrofág, eosinofil, keratinocita, microglia, endotheliál, és epitheliális sejtekben kimutatták az SPB2 mRNS és/ vagy fehérje szintjének növekedését intracellulárisan különböző körülmények hatására ${ }^{143-149}$. Ezen oknál fogva az SPB2 számos folyamatban részt vesz, például a szignál transzdukcióban, apoptózis gátlásában, makrofágok túlélését elősegítő folyamatokban, monocita és keratinocita sejtek differenciációjában, gyulladásos és immunfolyamatok szabályozásában ${ }^{143,150-157}$.

Az SPB2 mRNS vagy fehérje szintjében bekövetkező változást számos tumor típusnál kimutatták, azonban a szakirodalomban megtalálható eredmények igen változatosak. Az alacsony SPB2 expressziót összefüggésbe hozták a túlélési arány csökkenésével emésztőszervrendszeri-, emlő-, vagy tüdőrákban szenvedő páciensek esetében ${ }^{158-161}$. Továbbá orális elszarusodó laphámrák (oral SCC) esetében az SPB2 génjében bekövetkező génexpresszió csökkenést figyelték meg ${ }^{162}$. Ezen eredményekkel ellentétes az a megfigyelés, hogy melanoma tumorban az SPB2 túltermelése a szolubilis és sejtfelszín kapcsolt plazminogén aktivátorok gátlásával jár, így akadályozva az extracelluláris mátrix degradációját, mely a metasztázis első lépésének tekinthető. Ennek eredményeként az emelkedett SPB2 expresszió növeli a túlélési arányt melanoma esetében ${ }^{163,164}$.

Az SPB2 polimorfizmusát is összefüggésbe hozták különböző betegségekkel és szindrómákkal. Az SPB2 két polimorf formáját írták le, melyeknél a kodonokban bekövetkező báziskicserélődések miatt aminosav csere figyelhető meg a 120, 404 és 413. pozíciókban ${ }^{165,166}$. Nem tisztázott, hogy ezen változások milyen hatással vannak az SPB2 funkciójára, azonban az SPB2 A variánsát megfigyelték lupus erythematosus, thrombózisos tüdőgyulladásban, valamint antifoszfolipid szindrómában szenvedő pácienseknél 167,168. Ezen betegségekben közös pont a vérképződés szabályozásának zavara. Feltételezhetően az SPB2 normál körülmények között a vérképződés folyamatának szabályozásában is szerepet játszhat ${ }^{169}$. Továbbá Shioji és munkatársai kapcsolatot találtak az SPB2 A variánsa és a prosztata rák között, míg Di Bernardo és munkatársai pedig az SPB2 B variánsáról mutatták ki, hogy a nem-kissejtes tüdő karcinómás betegek túlélési arányát befolyásolja ${ }^{170,171}$. 
Mindezen eredmények arra utalhatnak, hogy az SPB2 számos fehérje mellett egy olyan protein, mely a szervezet homeosztázisának szabályozásában játszhat szerepet különböző sérülések, hibák és stresszhatások esetében.

\subsubsection{Az SPB10 fehérje jellemzése}

A SerpinB10 (SPB10), vagy másnéven Bomapin a Serpinek B kládjába tartozó redoxszenzitív hematopoetikus és mieloid leukémia specifikus sejtmagi fehérje. A protein a mieloid leukémia sejtek proliferációját segíti elö normál körülmények között, míg a növekedési faktorok hiányában a sejtek apoptózisát indukálja ${ }^{172}$. Miewald és munkatársainak sikerült kimutatni az SPB10 expresszióját a csontvelő sejtjeiben, azonban számos szövettípusban a fehérjét nem sikerült kimutatni, mint például a szív, agy, placenta, tüdő, máj, vázizom, vese, hasnyálmirigy, lép, csecsemőmirigy, prosztata vagy vastagbél ${ }^{173}$.

Az SPB10 fehérje szerkezetéről elmondható, hogy egy 22 aminosav hosszú CD-loop-pal rendelkezik, melyröl kimutatták, hogy nukleáris lokalizációs szignált tartalmaz ${ }^{174,175}$. A fehérje aminosav szekvenciája 48\%-ban megegyezik egy már jól jellemzett Serpinnel, az SPB2 - vel ${ }^{176}$.

Az SPB10 és SPB2 génben előforduló SNP missense mutációkról kimutatták, hogy a japán populációban előforduló prosztatarák kialakulásának kockázatát növelik ${ }^{171}$. Továbbá a szakirodalom szerint, az SPB10 mRNS expressziója emelkedik tüdőrákos páciensekben, míg mellrákos pácienseknél csökken ${ }^{163}$. Schleef és munkatársai kimutatták, hogy SPB10 túltermeltető vektorral kezelt HeLa sejtekben a TNF- $\alpha$ indukálta sejthalál csökken, mely szerintük az SPB10 fehérjének köszönhető ${ }^{175}$.

Az eddig leírt irodalom alapján látható, hogy a SerpinB klád igen diverz család, mely tagjainak funkciói igen sokrétűek. Feltételezhető, hogy az SPB klád tagjainak számos funkciója még ismeretlen, továbbá valószínüsíthető, hogy a már jellemzett funkciójú fehérjék egyéb, még nem leírt folyamatokban is részt vehetnek. 


\section{Célkitüzések}

Munkánk során elsődleges célunk volt az UV sugárzás, mint mindennapjainkat érintő környezeti faktor, és az általa kiváltott DNS károsodások, illetve ezekre adott sejtválaszban szerepet játszó folyamatok és fehérjék vizsgálata. Kutatócsoportunkkal nemrégiben közöltünk egy tanulmányt, melyben egy immortalizált keratinocita, a Hker E6SFM UV sugárzásra adott génexpresszió változásait vizsgáltuk a kontroll és UV sugárzással kezelt sejtek mRNS profiljának összehasonlításával ${ }^{177}$. Az UV kezelést követően emelkedett transzkripciós aktivitású gének közül kimutattuk a Serpin fehérjecsalád több tagját is, melyek szerepét korábban még nem vizsgálták a DNS károsodás hatására indukálódó sejtválaszban.

A kutatási irányvonalunk fổ célpontja az UV károsodás indukciója után a két legerősebb génexpresszió változást mutató SerpinB2 (SPB2) és SerpinB10 (SPB10) génekről termelödő fehérjék funkciójának jellemzése. A vizsgálatok során az alábbi kérdésekre kerestük a válaszokat:

\section{SPB2:}

1) Az elözetes microarray kísérletben tapasztalt $S P B 2$ transzkripciós aktivitás emelkedése UV sugárzás hatására Hker E6SFM sejtekben validálható-e kvantitatív realt-time PCR (qPCR) technika segítségével?

2) Az UV sugárzás hatására megemelkedő $S P B 2$ mRNS expresszió szint specifikus a Hker E6SFM sejtvonalra, esetleg más, bőrben előforduló sejtben is megfigyelhető ezen változás? A tapasztalt UV sugárzásra adott válasz csak bőrsejtekben figyelhető meg, vagy konzervált folyamat, így olyan sejtekben is kimutatható, melyek normál körülmények között nem érintkeznek UV sugárzással?

3) Az UV sugárzás befolyásolja-e az SPB2 fehérje szintjét? 
4) Számos proteáz stresszhatás következtében a citoplazmából a sejtmagba transzportálódik, ahol különböző sejtválasz folyamatokban vesz részt. Az UV sugárzás hatására mRNS és fehérje szinten is aktiválódó SPB2 feltételezhetően az UV sugárzás kiváltotta sejtválaszban szerepet játszó proteáz inhibítor. Vajon az SPB2 szubcellulláris lokalizációja változik-e UV kezelés hatására?

5) UV sugárzás következtében megfigyelhetö-e, hogy az SPB2 a sérült DNS régiókhoz kötődik? Az UV sugárzás mellett egyéb DNS károsító ágensek is kiválthatják-e ezt a hatást? Megfigyelhető-e az SPB2 lokalizációja azokban a sejtmagi pozíciókban, ahol a NER hibajavító fehérjéi felhalmozódnak?

6) Kimutatható-e fizikai kapcsolat az SPB2 és a NER útvonalban szerepet játszó XP fehérjék között, illetve megfigyelhető-e az SPB2 a hibajavítási fókuszokban, ahol a NER pre-incíziós komplex tagjai összeszerelödnek?

7) Az SPB2 ubiquitilált fehérjékhez képes kötődni, míg önmaga nem ubiquitilálódik. Az SPB2 kapcsolata a NER komplex-szel ubiquitiláció által közvetített poszt-transzlációs módosításokkal kapcsolt folyamat-e?

8) Lehet-e kapcsolat az SPB2 fehérje és a bazális sejtes karcinóma (BCC) között? Van-e különbség az SPB2 fehérje mennyiségében, vagy lokalizációjában az ép és tumoros szövetekben? 


\section{SPB10:}

9) Az előzetes microarray kísérletben tapasztalt SPB10 transzkripciós aktivitás emelkedése UV sugárzás hatására Hker E6SFM sejtekben validálható-e kvantitatív realt-time PCR (qPCR) technika segítségével? A tapasztalt UV sugárzásra adott válasz sejttípus specifikuse, vagy más in vitro fenntartott sejtvonalban is kimutatható-e?

10) Az SPB10 csendesítése befolyásolja-e a sejtek túlélését UV kezelés hatására?

11) Az SPB10 fehérje szerepet játszik-e az UV károsodás indukálta sejtválasz folyamatokban?

12) Az SPB10 feltételezett szerepe a DNS hibajavításban egy köztes fehérjén keresztül valósul meg, vagy az SPB10 közvetlenül a DNS-hez kötődik UV kezelést követően? 


\section{Anyagok és módszerek}

\subsection{Hker E6SFM, HaCaT, A375, U2OS és U2OS17 sejtek fenntartása}

Kísérleteink során az alábbi sejtvonalakat használtuk: a Hker E6SFM és HaCaT keratinocita, az A375 melanoma, a U2OS oszteoszarkóma, valamint az ebből származtatott U2OS17 178,179 sejtvonalat.

Az oszteoszarkóma (U2OS) sejtek ugyan fiziológiás állapotukban nincsenek kitéve UV sugárzásnak, azonban számos tudományos cikkben, mely a DNS hibajavítás és annak regulációjával foglalkozik, alkalmazzák ezen sejtvonalat. Továbbá ezen sejtvonal azért is alkalmas modell a hibajavítás vizsgálatára, mert szekvenálási eredmények kimutatták, hogy nem tartalmaz mutációt egyik DNS hibajavításban résztvevő fehérjét kódoló DNS szekvenciában sem.

A felhasznált sejtvonalakhoz a következő tápoldatokat használtuk: HaCaT, A375, U2OS sejteket 10\% FBS-t (Fetal Bovine Serum) (Lonza), 1\% antibiotikumot (Sigma-Aldrich) és 4 mM glutamint (Sigma-Aldrich) tartalmazó DMEM (Dulbecco's Modified Eagle Medium) (Lonza) tápoldatban növesztettünk $37^{\circ} \mathrm{C}$-on, $\mathrm{CO}_{2}$-os inkubátorban.

U2OS17 sejteket DMEM (Dulbecco's Modified Eagle Medium) (Lonza) tápoldatban növesztettünk, kiegészítve 10\% FBS-sel (Fetal Bovine Serum) (Lonza).

A Hker E6SFM sejtvonalat $37{ }^{\circ} \mathrm{C}$-on tartottuk kultúrában Keratinocyte-SFM Medium with L-Glutamine, EGF and BPE (Thermo Fisher Scientific) tápoldatban, kiegészítve $2 \mathrm{mM}$ glutaminnal és $1 \%$ antibiotikummal.

\subsection{Humán sejtek viabilitásának mérése tripánkék festékkel}

A sejtkultúrában növesztett és kitapadt sejteket tripszin segítségével felemésztettük, majd a felemésztett sejteket tartalmazó szuszpenzióban FBS segítségével leállítottuk a tripszin működését. A sejteket centrifuga segítségével összegyüjtöttük, majd megfestettük 0,4\%-os tripánkék és DMEM tápfolyadék 1:1 arányú oldatával. Az optimális festődés elérése érdekében a mintákat 10-15 percig inkubáltuk, majd Bürker kamra segítségével megszámoltuk és meghatároztuk az élő- és elpusztult sejtek arányát. 


\subsection{Humán sejtek életképességének mérése kristályibolya oldattal}

A kristályibolya bázikus színezőanyag, mely bejutva a DNS szálak közé (interkalálódó festékként) a sejtek DNS-ét festi meg. A 24-lyukú tenyésztőedényben felnövesztett sejtekről eltávolítottuk a tápoldatot, majd a felületüket PBS pufferrel [137 mM NaCl (Sigma-Aldrich), 2,7 mM KCl (Sigma-Aldrich), $10 \mathrm{mM} \mathrm{Na} 2 \mathrm{HPO}_{4}$ (Molar Chemicals), 1,8 mM KH${ }_{2} \mathrm{PO}_{4}$ (Molar Chemicals)] mostuk. Így az eljárás során a halott sejteket kimostuk és csak az élő sejtek maradtak a tenyésztőedényben letapadva. Ezáltal csak az élő sejtekben található nukleotidok festődnek, mely egyenesen arányos a sejtek számával (amely elsődlegesen a keletkezett kolóniák számától és kolónia méretétől függ), így azok számát tudjuk ezzel a módszerrel meghatározni. A folyadék óvatos eltávolítását követően a sejtekre $200 \mu 1$ 0,2\%os kristályibolya oldatot mértünk, mellyel 10 percig szobahőmérsékleten inkubáltuk. Ezt követően a sejteket kétszer mostuk desztillált vízzel, majd a festék sejtekböl történő kiszabadulása érdekében a sejteket $600 \mu 1$ 1\%-os SDS oldattal 10 percig kevertettük. Az oldat abszorbanciáját 590 nm-en BioTek-Synergy HTX multi-mode reader eszköz segítségével mértük meg. Az abszorbancia adatokból meghatároztuk a túlélő sejtek mennyiségét a kontrollhoz képest.

\subsection{UV sugárzás}

A sejtek UV kezelését steril kamrában, Viber Lourmat VL-/6. LM szürt UV lámpával végeztük, melyhez a sugárzás dózisát minden kezelés alkalmával UVX Digital Ultraviolet Intensity Meter (Cole-Palmer) készülékkel állítottuk be. A sejtek félletális dózissal (LD50) kezeltük, melynek meghatározásához előzetes kísérleteket végeztünk különböző intenzitású sugárzás alkalmazásával. A következő $\mathrm{LD}_{50}$ UV dózisokat alkalmaztuk kísérleteink során: $16 \mathrm{~mJ} / \mathrm{cm}^{2}$ U2OS, míg $80 \mathrm{~mJ} / \mathrm{cm}^{2}$ Hker E6SFM, HaCaT és A375 sejtvonal esetében. A sejteket az UV kezelés időtartama alatt egységes mennyiségü PBS-ben tartottuk [137 mM $\mathrm{NaCl}$ (Sigma-Aldrich), 2,7 mM KCl (Sigma-Aldrich), 10 mM Na $2 \mathrm{HPO}_{4}$ (Molar Chemicals), 1,8 mM KH${ }_{2} \mathrm{PO}_{4}$ (Molar Chemicals)], majd a kezelést követően visszahelyeztük öket kiegészített sejtkultúra tápoldatba (minden sejtvonal esetében a saját tápoldatát alkalmazva, mely a sejtek fenntartása címü fejezetben megtalálható). A PBS mennyisége az UV kezelés közben a tenyésztőedény nagyságától függött. $3,5 \mathrm{~cm}$ átmérőjü csészénél $1 \mathrm{ml}, 6 \mathrm{~cm}$-nél 3 ml, míg $10 \mathrm{~cm}$ átmérőjű csésze esetében $8 \mathrm{ml}$ PBS-t tettünk a sejtekre. Az UV kezelést követően a sejteket $37^{\circ} \mathrm{C}$-on inkubáltuk $2,4,8$ vagy 24 óráig. 


\section{5. $\mathrm{H}_{2} \mathrm{O}_{2}$ kezelés}

A U2OS sejteket $1,25 \mathrm{mM} \mathrm{H} \mathrm{O}_{2}$-dal kezeltük ( $\mathrm{LD}_{50}$ ), majd 2 órán keresztül $37{ }^{\circ} \mathrm{C}$-on inkubáltuk őket. Ezen idő eltelte után a sejteket PBS-sel 1137 mM NaCl (Sigma-Aldrich), 2,7 mM KCl (Sigma-Aldrich), $10 \mathrm{mM} \mathrm{Na} 2 \mathrm{HPO}_{4}$ (Molar Chemicals), 1,8 mM KH $\mathrm{KO}_{4}$ (Molar Chemicals)] mostuk, majd friss tápoldattal inkubáltuk öket 2 és 4 óra hosszáig.

\subsection{Neocarzinostatin (NCS) kezelés}

A sejteket 15 percig $50 \mathrm{ng} / \mathrm{ml}$ koncentrációjú NCS-sel kezeltük. A kezelést követően, a sejteket PBS-sel [137 mM NaCl (Sigma-Aldrich), 2,7 mM KCl (Sigma-Aldrich), $10 \mathrm{mM}$ $\mathrm{Na}_{2} \mathrm{HPO}_{4}$ (Molar Chemicals), 1,8 mM KH $2 \mathrm{PO}_{4}$ (Molar Chemicals)] mostuk, majd friss tápoldattal $37^{\circ} \mathrm{C}$-on inkubáltuk őket 2 és 4 óra hosszáig.

\subsection{Microarray}

Hker E6SFM keratinocita sejtvonalban az UV sugárzás hatására bekövetkező globális transzkripciós változásokat microarray kísérlettel vizsgáltuk. Az UV sugárzással kezelt és kontroll sejtekből teljes RNS-t izoláltunk RNeasy Mini Kit (Qiagen) segítségével, a gyártó elóírásának megfelelően. Minden kategória esetében három független mintagyüjtést alkalmaztunk. A teljes expressziós mintázat analízisére GeneChip Human Gene 1.0 ST array-t (Affymetrix) alkalmaztunk. Mintánként 250 ng teljes RNS típust tartalmazó mintát felhasználva cDNS-t készítettünk, majd amplifikáltunk és jelöltünk Ambion WT Expression Kit (Life Technologies) és GeneChip WT Terminal Labeling and Control Kit (Affymetrix) segítségével, a gyártó utasításait követve. Az analízist GenSpring GX7.3.1 (Agilent) szoftver segítségével végeztük, majd a mérésből származó adatokat (CEL file-ok) RMA algoritmus segítségével analizáltuk. A kapott eredmények normalizálásához per-chip normalization (global scaling) eljárást alkalmaztunk.

\subsection{Plazmid konstrukciók előállítása}

Új plazmidok létrehozásához specifikus klónozó primereket terveztünk, melyekkel felszaporítottuk az SPB2 és SPB10 fehérjéket kódoló génszakaszokat. Az amplifikációhoz tervezett primerek 5' végét restrikciós endonukleáz felismerőhellyel láttuk el, elősegítve ezzel a DNS szakasz plazmidba való beépítését. A tervezett klónozó primerek szekvenciáját a 1. táblázat tartalmazza. A PCR folyamat alatt az alábbi körülményeket alkalmaztuk: 98 
${ }^{\circ} \mathrm{C} 10$ másodperc, $65{ }^{\circ} \mathrm{C} 30$ másodperc, $72{ }^{\circ} \mathrm{C} 1$ perc, mindezt 40 cikluson keresztül. A felszaporított PCR terméket CloneJET PCR Cloning Kit segítségével (Thermo Fisher Scientific) klónozó plazmidba ligáltuk, a gyártó elöírásait követve. Ezt követően pEGFP-C1 célvektorba építettük át az inszerteket, SPB2 esetében BglII és EcoRI, míg SPB10 alkalmával BglII és SalI restrikciós enzimhasítási helyek és azok felismerő enzimjeinek segítségével.

\begin{tabular}{|c|c|c|c|c|}
\hline $\begin{array}{l}\text { Plazmid } \\
\text { neve }\end{array}$ & $\begin{array}{l}\text { Használt } \\
\text { restrikciós } \\
\text { endonukleáz }\end{array}$ & $\begin{array}{l}\text { Forward primer } \\
\text { szekvenciája }\left(5^{\prime}-3^{\prime}\right)\end{array}$ & $\begin{array}{l}\text { Használt } \\
\text { restrikciós } \\
\text { endonukleáz }\end{array}$ & $\begin{array}{l}\text { Reverse primer } \\
\text { szekvenciája }\left(5^{\prime}-3^{\prime}\right)\end{array}$ \\
\hline $\begin{array}{l}p E G F P C 1 \\
-S P B 2\end{array}$ & $\mathrm{BglII}$ & $\begin{array}{l}\text { ATAAGATCTGA } \\
\text { GGATCTTTGTGT } \\
\text { GGCA }\end{array}$ & EcoRI & $\begin{array}{l}\text { CGAATTCTTAGG } \\
\text { GTGAGGAAAATC } \\
\text { TGC }\end{array}$ \\
\hline $\begin{array}{l}\text { pEGFPC1 } \\
-S P B 10\end{array}$ & $\mathrm{BgIII}$ & $\begin{array}{l}\text { GCGAGATCTGA } \\
\text { CTCTCTAGCAA } \\
\text { CATCA }\end{array}$ & SalI & $\begin{array}{l}\text { ATGTCGACTTAG } \\
\text { GGGGAGCATAAT } \\
\text { CT }\end{array}$ \\
\hline
\end{tabular}

1. táblázat: Az alkalmazott klónozó primerek adatai

\subsection{Baktérium transzformáció és plazmid tisztítás}

A ligált plazmidokat E. coli DH5 $\alpha$ baktérium kultúrába juttattuk és felszaporítottuk, majd a további felhasználás érdekében Macherey-Nagel NucleoBond Xtra Midi kittel tisztítottuk, a gyártó előírásának megfelelően.

\subsection{Humán sejtek transzfekciója plazmid DNS-sel}

U2OS sejteket $10 \mathrm{~cm}$ átméröjü csészében növesztettünk, majd transzfektáltuk őket 7,5 $\mu \mathrm{g}$ plazmid DNS-sel, jetPEI transzfekciós reagens (Polyplus) segítségével, a gyártó előírásainak megfelelően. A transzfektált sejtek aránya a transzfekciós kísérletek során minimum $50 \%$ volt. Az eljárást követően a sejteket 24 órán keresztül $37{ }^{\circ} \mathrm{C}$-on, $\mathrm{CO}_{2}$ inkubátorban növesztettük. Az inkubációs idő lejárta elött 2 és 4 órával a sejteket UV sugárzással kezeltük. A kísérletek során használt plazmidok listája a 2. táblázatban található. 


\begin{tabular}{|l|}
\hline Alkalmazott plazmid neve \\
\hline pEGFPC1 üres vektor \\
\hline pEGFPC1-SPB2 vektor \\
\hline pEGFPC1-SPB10 vektor \\
\hline pcDNA-HA-ubiquitin vektor \\
\hline pEGFPC1-XPC vektor \\
\hline
\end{tabular}

2. táblázat: Kísérletek során alkalmazott plazmidok

\subsection{RNS izolálás humán sejtekből és reverz transzkripciós reakció}

Humán sejtekből teljes RNS-t izoláltunk ReliaPrep RNA Cell Miniprep System Kit (Promega) segítségével, a gyártó által mellékelt protokoll szerint. A minták RNS koncentrációját NanoDrop (ND-1000 Spectrophotometer) műszerrel határoztuk meg. Minden minta esetében $1 \mu \mathrm{g}$ mennyiségű RNS-t írtunk át cDNS-re TaqMan Reverse Transcription reagens (Thermo Fisher Scientific) használatával, a gyártó által megadott útmutatás szerint. A folyamat alatt az alábbi körülményeket használtunk: $25{ }^{\circ} \mathrm{C} 10$ perc, 37 ${ }^{\circ} \mathrm{C} 60$ perc és $95^{\circ} \mathrm{C} 5$ perc.

\subsection{SPB2 és SPB10 primer tervezése}

A génexpresszió mérésekhez specifikus primereket terveztünk Primer3 szoftver segítségével. Belső kontrollként 18S RNS-re specifikus primerpárt használtunk, melyet Dr. Újfaludi Zsuzsanna tervezett ${ }^{177}$. Az alkalmazott primerpárok listája és szekvenciája a 3. táblázatban szerepel.

\begin{tabular}{|l|l|l|}
\hline Gén neve & Forward primer szekvenciája (5'-3') & Reverse primer szekvenciája (5'-3') \\
\hline SPB2 & GATGTGTCCACTGGCTTGGA & CCTCTCCGACATCCCTGAGA \\
\hline$S P B 10$ & CAAGCAAACCAGTGCAAATG & TAGGTGATGGCCTTTTCCAG \\
\hline $18 S R N S$ & AAACGGCTACCACATCCAAG & CGCTCCCAAGATCCAACTAC \\
\hline
\end{tabular}

3. táblázat: A génexpresszió méréseknél alkalmazott primerpárok

\subsection{Génexpresszió mérése kvantitatív real time PCR (qPCR) technikával}

A kvantitatív real-time PCR reakciókat Thermo Scientific PikoReal Real-Time PCR készülékkel végeztük. A reakció során keletkező termékek kvantitatív meghatározásához 
SYBR Green PCR Master Mixet használtunk (Thermo Fisher Scientific). A reakciók során az alábbi körülményeket alkalmaztuk: $95^{\circ} \mathrm{C} 10$ perc, $95^{\circ} \mathrm{C} 15$ másodperc, $60{ }^{\circ} \mathrm{C} 1$ perc, 40 cikluson keresztül. A reakció végén olvadási görbe analízis segítségével határoztuk meg a termék minőségét, kizárva az esetleges primer-dimerek detektálását. A minták „cycle treshold” (Ct) értékét normalizáltuk 18S RNS belső kontroll segítségével, majd a gének relatív expresszió értékét $\Delta \Delta \mathrm{Ct}$ metódussal számoltuk ki ${ }^{180}$. Kísérleteink során három egymástól függetlenül gyüjtött mintasorozaton végeztük a méréseket.

\subsection{Western blot}

A sejteket összegyüjtöttük, majd a feltárásuk érdekében egy órán át jégen inkubáltuk lízis pufferben [150 mM NaCl (Sigma-Aldrich), 1\% Triton X-100 (Molar Chemicals), $50 \mathrm{mM}$ Tris-HCl pH 8 (Sigma-Aldrich) és 1xPIC (Roche)]. Ezután a sejttörmeléket centrifugálással (13000 RPM, 5 perc, $4{ }^{\circ} \mathrm{C}$ ) ülepítettük ki. A felülúszó fehérje koncentrációját Bradford reagens (Bio-Rad, 500-006) segítségével mértük meg. Ezt követően minden mintából $30 \mu \mathrm{g}$ fehérjét, megfelelő térfogatú 5\% $\beta$-merkaptoetanol tartalmú 2xSDS mintafelvivő pufferben (Sigma-Aldrich) 5 percig, $100{ }^{\circ} \mathrm{C}$-on forraltuk. A fehérjéket SDS-PAGE segítségével elválasztottuk, majd nitrocellulóz membránra (GE Healthcare) rögzítettük. Az aspecifikus kötőhelyek felismerésének elkerülése érdekében a membránokat egy éjszakán keresztül 5\%os tejpor-TBST oldatban blokkoltuk [20 mM Tris-HCl pH 7.4 (Sigma-Aldrich), $150 \mathrm{mM}$ $\mathrm{NaCl}$ (Sigma- Aldrich), 0,05\% Tween 20 (Molar Chemicals)].

Másnap 1x TBST pufferrel történő mosásokat követően, a membránt 1,5 órán át inkubáltuk elsődleges ellenanyaggal, melyet 1\%-os tejpor-TBST-ben oldottunk. Ezt követően ismét mostuk a membránt 1x TBST pufferrel, majd egy óráig torma-peroxidázzal (HRP) konjugált másodlagos ellenanyaggal inkubáltuk, mely az elsődleges ellenanyagra specifikus (GARgoat anti rabbit, valamint RAM- rabbit anti mouse). A Western blot során alkalmazott ellenanyagok listája a 4. táblázatban szerepel.

A kemilumineszcens jel előhívásához Immobilon Western Chemiluminescent HRP reagenst (Merck Millipore) alkalmaztunk, amit Li-Cor 3600 C-DiGit Blot Scanner készülékkel detektáltunk. A kapott mintasorozatokban a jel intenzitását Fiji (ImageJ) szoftverrel értékeltük ki 


\begin{tabular}{|c|c|c|c|c|c|c|c|}
\hline \multicolumn{4}{|c|}{ Elsődleges ellenanyag } & \multicolumn{4}{|c|}{ Másodlagos ellenanyag } \\
\hline Neve & $\begin{array}{l}\text { Hígítás } \\
\text { (IP- } \\
\text { nál) }\end{array}$ & $\begin{array}{l}\text { Hígítás } \\
\text { (Inputnál) }\end{array}$ & $\begin{array}{l}\text { Gyártó és } \\
\text { kat. száma }\end{array}$ & Neve & $\begin{array}{l}\text { Hígítás } \\
\text { (IP-nál) }\end{array}$ & $\begin{array}{l}\text { Hígítás } \\
\text { (Inputnál) }\end{array}$ & $\begin{array}{l}\text { Gyártó } \\
\text { és kat. } \\
\text { száma }\end{array}$ \\
\hline $\begin{array}{l}\text { anti- } \\
\text { SPB2 }\end{array}$ & - & $50 \mathrm{x}$ & $\begin{array}{l}\text { Atlas } \\
\text { Antibodies, } \\
\text { HPA015480 }\end{array}$ & $\begin{array}{l}\text { GAR- } \\
\text { HRP }\end{array}$ & - & $200 x$ & $\begin{array}{l}\text { Dako, } \\
\text { P0448 }\end{array}$ \\
\hline $\begin{array}{l}\text { anti- } \\
\text { Lamin A }\end{array}$ & - & $50 \mathrm{x}$ & $\begin{array}{l}\text { Santa Cruz, } \\
\text { sc-293162 }\end{array}$ & $\begin{array}{l}\text { RAM- } \\
\text { HRP }\end{array}$ & - & $200 x$ & $\begin{array}{l}\text { Dako, } \\
\text { P0260 }\end{array}$ \\
\hline anti-H3 & $1500 x$ & $3000 x$ & $\begin{array}{l}\text { Abcam, } \\
\text { ab1791 }\end{array}$ & $\begin{array}{l}\text { GAR- } \\
\text { HRP }\end{array}$ & $3000 x$ & $6000 x$ & $\begin{array}{l}\text { Dako, } \\
\text { P0448 }\end{array}$ \\
\hline $\begin{array}{l}\text { anti- } \\
\text { GFP }\end{array}$ & $500 x$ & $1000 x$ & $\begin{array}{l}\text { Abcam, } \\
\text { ab6556 }\end{array}$ & $\begin{array}{l}\text { GAR- } \\
\text { HRP }\end{array}$ & $1000 x$ & $2000 x$ & $\begin{array}{l}\text { Dako, } \\
\text { P0448 }\end{array}$ \\
\hline anti-HA & $500 x$ & $2000 x$ & IGBMC & $\begin{array}{l}\text { RAM- } \\
\text { HRP }\end{array}$ & $1000 x$ & $4000 x$ & $\begin{array}{l}\text { Dako, } \\
\text { P0260 }\end{array}$ \\
\hline $\begin{array}{l}\text { anti- } \\
\text { Tubulin }\end{array}$ & - & $2000 x$ & $\begin{array}{l}\text { Sigma, } \\
\text { T9026 }\end{array}$ & $\begin{array}{l}\text { RAM- } \\
\text { HRP }\end{array}$ & - & $4000 x$ & $\begin{array}{l}\text { Dako, } \\
\text { P0260 }\end{array}$ \\
\hline $\begin{array}{l}\text { anti-S2P } \\
\text { Pol II }\end{array}$ & $350 x$ & $1000 x$ & $\begin{array}{l}\text { Abcam, } \\
\text { ab5095 }\end{array}$ & $\begin{array}{l}\text { GAR- } \\
\text { HRP }\end{array}$ & $1500 x$ & $4000 x$ & $\begin{array}{l}\text { Dako, } \\
\text { P0448 }\end{array}$ \\
\hline
\end{tabular}

4. táblázat: A Western blot során alkalmazott ellenanyagok. A táblázatban szereplő rövidítések a rövidítések jegyzékében találhatók.

\subsection{Frakcionált sejtlizátum készítése Western blot technikához}

Az eljárás kezdetén a sejteket 1xPIC-kel kiegészített PBS pufferben [137 mM NaCl (SigmaAldrich), 2,7 mM KCl (Sigma-Aldrich), 10 mM Na $2 \mathrm{HPO}_{4}$ (Molar Chemicals), 1,8 mM $\mathrm{KH}_{2} \mathrm{PO}_{4}$ (Molar Chemicals)] összegyüjtöttük, majd centrifugálással koncentráltuk őket a cső aljára. A kiülepített sejteket hipotóniás pufferben $[10 \mathrm{mM}$ Tris-HCl pH 8.0 (Sigma-Aldrich), 1,5 $\mathrm{mM} \mathrm{MgCl} 2$ (Sigma-Aldrich), $10 \mathrm{mM} \mathrm{KCl} \mathrm{(Sigma-Aldrich),} \mathrm{1xPIC} \mathrm{(Roche)]}$ visszaoldottuk és $21 \mathrm{G}$ átmérőjü tű segítségével homogenizáltuk. Ezt követően szukróz puffert [20 mM Tris-HCl pH 8.0 (Sigma-Aldrich), 15 mM KCl (Sigma-Aldrich), $60 \mathrm{mM}$ $\mathrm{NaCl}$ (Sigma-Aldrich), 0,34 mM szukróz (Sigma-Aldrich), 0,15 mM Spermine (SigmaAldrich), 0,5 mM Spermidine (Sigma-Aldrich), 1xPIC (Roche)] adtunk a lizátumhoz, majd 
centrifugálással (10000 RPM/ 10 perc/ $\left.4{ }^{\circ} \mathrm{C}\right)$ választottuk el a felülúszóként megjelenő citoplazmatikus frakciót a többi összetevőtől. A megmaradó csapadékot ismét szukróz pufferben visszaoldottuk, majd kiegészítettük magas só tartalmú pufferrel [20 mM Tris- $\mathrm{HCl}$ pH 8.0 (Sigma-Aldrich), 25\% Glycerol (Fermentas), 1,5 mM MgCl 2 (Sigma-Aldrich), 0,2 mM EDTA (Sigma-Aldrich), 900 mM NaCl (Sigma-Aldrich), 1xPIC (Roche)]. Ezt követően időnként megkeverve őket, fél óráig jégen tároltuk a mintákat. Ismételten centrifugálással választottuk el a kromatinhoz nem kötődő fehérjéket tartalmazó frakciót. A visszamaradó kromatin kötött fehérje frakciót szukróz pufferben felszuszpendáltuk és 6 percig, 30 másodperc ON és 30 másodperc OFF beállítással Diagenode Bioruptor (Diagenode) szonikátor felhasználásával fragmentáltuk. A szonikált minták az inszolubilis nukleáris frakciónak feleltek meg, melyet centrifugálással gyüjtöttünk össze. Az eljárás során keletkezett mintákat Western blot technika segítségével analizáltuk.

\subsection{CSK immunhiszokémiai eljárás alkalmazása humán sejteken}

A sejteket PBS pufferrel [137 mM NaCl (Sigma-Aldrich), 2,7 mM KCl (Sigma-Aldrich), 10 $\mathrm{mM} \mathrm{Na} \mathrm{HPO}_{4}$ (Molar Chemicals), 1,8 mM KH $2 \mathrm{PO}_{4}$ (Molar Chemicals)] történő mosást követően háromszor három percig CSK pufferrel inkubáltuk [10 mM Hepes pH 7.0 (SigmaAldrich), $100 \mathrm{mM}$ sucrose (Sigma-Aldrich), $3 \mathrm{mM} \mathrm{MgCl} 2$ (Sigma-Aldrich), 0,7\% Triton X100 (Sigma-Aldrich), 0,3 mg/ml RNase A (Roche)] annak érdekében, hogy eltávolítsuk a sejtek citoplazmatikus és szolubilis nukleáris frakcióját. Ezt követően PBS pufferrel háromszor mostuk a sejteket, majd 10 perc inkubációs idő alkalmazásával, 4\% formaldehid (Sigma-Aldrich) oldattal rögzítettük őket a tárgylemezhez. Ismételt PBS pufferrel történő mosást követően feltártuk a sejteket $0,2 \%$ Triton X-100/PBS (Fluka) permeabilizáló oldat 5 percig való alkalmazásával. PBS oldattal átmostuk a sejteket, majd 20 percig blokkoltuk őket 5\% BSA-PBST [BSA (Sigma-Aldrich), 0,1\% Tween 20 (Sigma-Aldrich), PBS] oldatban, az aspecifikus jelek eltávolítása érdekében. A sejteket PBST oldattal mostuk, majd 1,5 óráig inkubáltuk specifikus elsődleges ellenanyaggal, melyet 1\% BSA-PBST pufferben oldottunk. Ismételt PBST pufferrel történő mosást követően 1 óra inkubálás következett fluorofórral konjugált másodlagos ellenanyaggal, mely az elsődleges ellenanyagra specifikus (GAR- goat anti rabbit, valamint GAM- goat anti mouse). Az eljárás során alkalmazott ellenanyagok listája az 5. táblázatban szerepel. Az eljárás végén a sejteket PBS oldattal mostuk, majd interkalálódó DAPI festéket tartalmazó ProLong Gold reagenssel (Thermo Fisher Scientific) fedtük le. A mintákat Olympus FluoView FV1000 konfokális 
mikroszkóppal vizsgáltuk. Minden egyes kezelés esetében a mintáknál azonos expozíciós időt alkalmaztuk. A kapott fluoreszcencia intenzitását Fiji (Image J) szoftverrel értékeltük ki.

\begin{tabular}{|l|l|l|l|l|l|}
\hline \multicolumn{2}{|l|}{ Elsődleges ellenanyag } & \multicolumn{2}{l|}{ Másodlagos ellenanyag } \\
\hline Specifitása & Hígítása & $\begin{array}{l}\text { Gyártó és kat. } \\
\text { száma }\end{array}$ & Specificitása & Hígítása & $\begin{array}{l}\text { Gyártó és kat. } \\
\text { száma }\end{array}$ \\
\hline anti-SPB2 & $300 x$ & $\begin{array}{l}\text { Atlas } \\
\text { Antibodies, } \\
\text { HPA015480 }\end{array}$ & $\begin{array}{l}\text { GAR } \\
\text { Dylight 550 }\end{array}$ & $600 x$ & $\begin{array}{l}\text { Abcam, } \\
\text { ab96984 }\end{array}$ \\
\hline anti-XPB & $1000 x$ & IGBMC & GAM Alexa & $2000 x$ & $\begin{array}{l}\text { Thermo Fisher } \\
\text { Scientific, } \\
\text { A11029 }\end{array}$ \\
\hline anti-XPF & $1000 x$ & IGBMC & GAM Alexa & $2000 x$ & $\begin{array}{l}\text { Thermo Fisher } \\
\text { Scientific, } \\
\text { A11029 }\end{array}$ \\
\hline
\end{tabular}

5. táblázat: A CSK-immunhisztokémia során alkalmazott ellenanyagok. A táblázatban szereplő rövidítések a rövidítések jegyzékében találhatók.

\subsection{Immunhisztokémiai eljárás alkalmazása humán sejteken}

A sejteket PBS pufferrel [137 mM NaCl (Sigma-Aldrich), 2,7 mM KCl (Sigma-Aldrich), 10 $\mathrm{mM} \mathrm{Na} 2 \mathrm{HPO}_{4}$ (Molar Chemicals), 1,8 mM KH $2 \mathrm{PO}_{4}$ (Molar Chemicals)] történő mosást követően 30 percig 4\%-os formaldehid (Sigma-Aldrich) oldattal rögzítettük a tárgylemezhez. Ismételt PBS pufferrel történő mosást követően feltártuk a sejteket $0,3 \%$ Triton X-100/PBS (Fluka) permeabilizáló oldat 20 percig való alkalmazásával. Mostuk a sejteket PBS pufferrel, majd 20 percig blokkoltuk őket 5\% BSA-PBST [BSA (SigmaAldrich), 0,1\% Tween 20 (Sigma-Aldrich), PBS] oldatban, az aspecifikus kötőhelyek blokkolása érdekében. A sejteket PBST [0,1\% Tween 20 (Sigma-Aldrich), PBS] oldattal mostuk, majd 1,5 óráig inkubáltuk specifikus elsődleges ellenanyaggal, melyet 1\% BSAPBST pufferben oldottunk. Ismételt PBST pufferrel történő mosást követően 1 óra inkubálás következett fluorofórral konjugált másodlagos ellenanyag oldatának segítségével. Az eljárás során alkalmazott ellenanyagok listája a 6. táblázatban szerepel. Az eljárás végén a sejteket mostuk PBST pufferrel, majd interkalálódó DAPI festéket tartalmazó ProLong Gold 
antifade reagenssel (Thermo Fisher Scientific) fedtük le. A mintákat Olympus FluoView FV1000 konfokális mikroszkóppal vizsgáltuk. Egy kísérleten belül minden egyes minta esetében azonos expozíciós időt alkalmaztuk.

\begin{tabular}{|l|l|l|l|l|l|}
\hline \multicolumn{2}{|l|}{ Elsődleges ellenanyag } & \multicolumn{3}{l|}{ Másodlagos ellenanyag } \\
\hline Specifitása & Hígítása & $\begin{array}{l}\text { Gyártó és kat. } \\
\text { száma }\end{array}$ & Specificitása & Hígítása & $\begin{array}{l}\text { Gyártó és kat. } \\
\text { száma }\end{array}$ \\
\hline anti-SPB2 & $300 x$ & $\begin{array}{l}\text { Atlas } \\
\text { Antibodies, } \\
\text { HPA015480 }\end{array}$ & $\begin{array}{l}\text { GAR } \\
\text { Dylight 550 }\end{array}$ & $600 x$ & $\begin{array}{l}\text { Abcam, } \\
\text { ab96984 }\end{array}$ \\
\hline anti-Tubulin & $500 x$ & Sigma, T9026 & GAM Alexa & $1000 x$ & $\begin{array}{l}\text { Thermo Fisher } \\
\text { Scientific, } \\
\text { A11029 }\end{array}$ \\
\hline
\end{tabular}

6. táblázat: A humán sejteken elvégzett immunhisztokémia eljárás során alkalmazott

ellenanyagok. A táblázatban szereplő rövidítések a rövidítések jegyzékében találhatók.

\subsection{Immunhisztokémia humán szöveteken}

A $7 \mu \mathrm{m}$ vastagságú paraffinizált bazális sejtes karcinóma (BCC) metszeteket xilol (SigmaAldrich) tartalmú deparaffinizáló oldatba merítettük háromszor 15 percre, majd kétszer mostuk 96\% és egyszer 70\% etanol tartalmú oldattal a paraffin szövetek közüli eltávolítása érdekében. Ezt követően a mintákat desztillált vízzel, majd PBS oldattal $[137 \mathrm{mM} \mathrm{NaCl}$ (Sigma-Aldrich), 2,7 mM KCl (Sigma-Aldrich), 10 mM Na $2 \mathrm{HPO}_{4}$ (Molar Chemicals), 1,8 $\mathrm{mM} \mathrm{KH}{ }_{2} \mathrm{PO}_{4}$ (Molar Chemicals)] mostuk. A mintafeltárást EnVision FLEX Target Retrieval Solution alacsony pH-jú pufferrel (Dako, K8005) végeztük 15 percig emelkedő hőmérséklet mellett $\left(65-92{ }^{\circ} \mathrm{C}\right)$. A mintákat 15 perc hütést követően PBS oldattal mostuk, majd 1 óráig blokkoltuk őket 5\% BSA/ 0,3\% Triton X-100-PBS oldatban, az aspecifikus kötőhelyek blokkolása érdekében. Ezt elősegítve a blokkoló oldatba torma-peroxidázzal konjugált másodlagos ellenanyagokkal [GAR HRP (Dako, P0448) és RAM HRP (Dako, P0260)] egészítettük ki 1:2000 hígításban. PBST pufferrel PBST [0,1\% Tween 20 (Sigma-Aldrich), PBS] történő mosást követően, 1\% BSA-PBST pufferben oldott specifikus elsődleges antitestekkel 1,5 órán át, majd ezt követően fluorofórral konjugált másodlagos ellenanyagokkal a mintákat 1 órát inkubáltuk. A felhasznált antitestek listáját a 7. táblázat tartalmazza. Az eljárás végén a sejteket PBST pufferrel mostuk, majd interkalálódó DAPI 
festéket tartalmazó ProLong Gold reagenssel (Thermo Fisher Scientific) fedtük le. A mintákat Leica SP5 konfokális mikroszkóppal vizsgáltuk. Minden egyes minta esetében azonos expozíciós időt alkalmaztunk. A kapott fluoreszcencia intenzitását Fiji (Image J) szoftver, Plot profile plugin eszköz segítségével értékeltük ki.

\begin{tabular}{|c|c|c|c|c|c|}
\hline \multicolumn{3}{|c|}{ Elsődleges ellenanyag } & \multicolumn{3}{|c|}{ Másodlagos ellenanyag } \\
\hline Specifitása & Hígítása & $\begin{array}{l}\text { Gyártó és kat. } \\
\text { száma }\end{array}$ & Specificitása & Hígítása & $\begin{array}{l}\text { Gyártó és kat. } \\
\text { száma }\end{array}$ \\
\hline anti-SPB2 & $50 x$ & $\begin{array}{l}\text { Atlas } \\
\text { Antibodies, } \\
\text { HPA015480 }\end{array}$ & $\begin{array}{l}\text { GAR Alexa } \\
555\end{array}$ & $100 x$ & $\begin{array}{l}\text { Invitrogen, } \\
\text { A21429 }\end{array}$ \\
\hline anti-Pol II & $250 x$ & IGBMC (7G5) & $\begin{array}{l}\text { GAM Alexa } \\
488\end{array}$ & $500 x$ & $\begin{array}{l}\text { Molecular } \\
\text { Probes, A11029 }\end{array}$ \\
\hline
\end{tabular}

7. táblázat: A humán sejteken elvégzett immunhisztokémia eljárás során alkalmazott

ellenanyagok. A táblázatban szereplő rövidítések a rövidítések jegyzékében találhatók.

\subsection{A humán szövetek hematoxilin és eozin festése}

A festési módszert a bazális sejtes karcinóma (BCC) metszetek tumoros és ép régióinak elkülönítése érdekében alkalmaztuk. Első lépésként a metszeteket timsós hematoxilin oldattal (Sigma-Aldrich) festettük, majd a mintákat desztillált vízzel mostuk és a mosást követően a mintákat 1g/l-es koncentrációjú eozin-B oldattal (Sigma-Aldrich) festettük meg. Ezt követően a metszeteket kétszer mostuk desztillált vízzel, és egyszer izopropil-alkohollal, majd ismételten desztillált vizes mosás következett. Ezt követően vízmentesítettük, derítettük, majd lefedtük a mintákat. A metszetek hiszto-architektúrájának változását Olympus FluoView FV1000 konfokális mikroszkóppal vizsgáltuk.

\subsection{LacO-tethering eljárás}

U2OS17 sejteket 24-lyukú tenyésztőedényben növesztettük, majd FuGENE transzfekciós reagens (Promega) használatával $1 \mu \mathrm{g}$ plazmid DNS-t juttatunk a sejtekbe, a gyártó elöírásainak megfelelően. Az eljárást követően a sejteket 24 órán keresztül $37^{\circ} \mathrm{C}$-on, $\mathrm{CO}_{2}$ inkubátorban növesztettük, majd immunfluoreszcens festéssel tettük láthatóvá a fehérjéket. Az inkubációs idő lejárta előtt 1 órával a sejteket $12 \mathrm{~mJ} / \mathrm{cm}^{2}$ erösségü UV sugárzással kezeltük. A felhasznált plazmidok listája a 8. táblázatban szerepel. Kísérleteink során 
három egymástól függetlenül festett mintasorozaton végeztük az analízist, 100 sejt/kondíciót megmérve.

\begin{tabular}{|l|}
\hline Alkalmazott plazmidok nevei \\
\hline GFP-LacR-NLS vektor \\
\hline GFP-LacR-XPB vektor \\
\hline GFP-LacR-XPB $\triangle N$ vektor \\
\hline
\end{tabular}

\section{8. táblázat: A LacO-tethering eljárás során alkalmazott plazmidok}

\subsection{Ko-immunprecipitáció}

U2OS sejteket PBS pufferrel [137 mM NaCl (Sigma-Aldrich), 2,7 mM KCl (SigmaAldrich), $10 \mathrm{mM} \mathrm{Na} 2 \mathrm{HPO}_{4}$ (Molar Chemicals), $1,8 \mathrm{mM} \mathrm{KH} \mathrm{PO}_{4}$ (Molar Chemicals)] mostuk és centrifugálással (6000 RPM, 5 perc, $4{ }^{\circ} \mathrm{C}$ ) összegyüjtöttük, majd 1 óra jégen történő inkubáció alatt nem denaturáló lízis pufferben [150 mM NaCl (Sigma-Aldrich), $1 \%$ Triton X-100 (Molar Chemicals), 50 mM Tris-HCl pH 8.0 (Sigma-Aldrich) és 1xPIC (Roche)] feltártuk. Ezek után centrifugálással megszabadultunk az esetlegesen keletkezett sejttörmeléktől. A felülúszóban lévő fehérje oldat koncentrációját Bradford reagenssel (BioRad, 500-006) megmértük. Minden mintából $250 \mu \mathrm{g}$ fehérjét előtisztítottunk $15 \mu 1$ egyesszálú DNS-sel blokkolt Protein A-Sepharose gyönggyel (Sigma.Aldrich). Ezen folyamat 2 órán keresztül, $4{ }^{\circ} \mathrm{C}$-on zajlott, majd a gyöngyöket centrifugálással (6000 RPM, 5 perc, $\left.4{ }^{\circ} \mathrm{C}\right)$ eltávolítottuk. Ezt követően a mintákhoz megfelelö mennyiségű elsődleges ellenanyagot adtunk, mellyel $4{ }^{\circ} \mathrm{C}$-on egy éjszakán át kevertettük. A nem specifikus fehérje kötődések kizárása érdekében negatív kontrollként olyan mintát készítettünk, amelynél nem használtunk ellenanyagot (no antibody control- NAC). Másnap minden mintához $40 \mu 1$ blokkolt Protein A-Sepharose gyöngyöt adtunk, és egy újabb éjszakán át kevertettük. Az inkubációs idő lejárta után a gyöngyöket centrifugálással (1000 RPM, 5 perc, $\left.4{ }^{\circ} \mathrm{C}\right)$ összegyüjtöttük. Miután négyszer mostuk a gyöngyöket nem denaturáló lízis pufferrel, eluáltuk a mintákat 5\% $\beta$-merkaptoetanol tartalmú 2xSDS loading pufferben (SigmaAldrich) 5 percig való forralással. Ezt követően centrifugálással kiülepítettük, majd eltávolítottuk a gyöngyöket. Az immunprecipitációs kísérletben a kölcsönható fehérjék jelenlétét Western Blot technika alkalmazásával, a célfehérjékre specifikus ellenanyagok felhasználásával mutattuk ki. A kísérletek során használt ellenanyagok listája a 9. táblázatban szerepel. 


\begin{tabular}{|l|l|}
\hline Felhasznált ellenanyag neve & Gyártó és kat. száma \\
\hline anti-HA & IGBMC (12CA5) \\
\hline anti-H3 & Abcam, ab1791 \\
\hline anti-GFP & Abcam, ab6556 \\
\hline
\end{tabular}

9. táblázat: A ko-immunprecipitációs eljárások során alkalmazott ellenanyagok

\subsection{Comet-esszé}

Az siSPB10 és siSCR RNS-sel transzfektált U2OS sejteket bromodeoxyuridine (BrdU) festékkel jelöltük, hogy láthatóvá tegyük az S-fázisban lévő sejtek replikációs villáit, illetve a DNS hibák javítása során létrejött egyes-szálú DNS szakaszokat. Az eljárás során a sejteket 20 percig, $37{ }^{\circ} \mathrm{C}$-on kezeltük $20 \mu \mathrm{M}$ BrdU tartalmú DMEM tápoldattal, majd a sejteket PBS oldattal [137 mM NaCl (Sigma-Aldrich), 2,7 mM KCl (Sigma-Aldrich), $10 \mathrm{mM} \mathrm{Na} 2 \mathrm{HPO}_{4}$ (Molar Chemicals), 1,8 mM KH $\mathrm{KHO}_{4}$ (Molar Chemicals)] mostuk, és UV sugárzással kezeltük őket. A kezelés után a sejtekre frissen bekevert $200 \mu \mathrm{M} 4 \mathrm{x}$ dNTP tartalmú tápoldatot tettünk, majd 0 , 6 és 24 órán keresztül $37^{\circ} \mathrm{C}$-os $\mathrm{CO}_{2}$ inkubátorba helyeztük őket. Az inkubációs idő lejárta után a sejteket PBS pufferrel mostuk, majd a kitapadt sejteket tripszin segítségével felemésztettük és szuszpenzióba vittük. Az így kapott sejt szuszpenziót centrifugálással $\left(200 \mathrm{~g}, 5\right.$ perc) kiülepítettük, majd feloldottuk $70 \mu 137^{\circ} \mathrm{C}$-os $0,75 \%$-os alacsony olvadáspontú agarózban (Sigma-Aldrich). Ezt követően az agaróz-sejtpellet keverékét az előre elkészített $1 \%$ agarózzal borított tárgylemezre cseppentettük és fedőlemezzel leborítottuk, így egy egységes, vékony réteget létrehozva a két üvegfelület között. A sejtpelletes- agaróz réteg megdermedése érdekében a tárgylemezeket $4{ }^{\circ} \mathrm{C}$-ra helyeztük 3 percre. Ezt követően a fedőlemezeket óvatosan eltávolítottuk a mintákról. A sejteket tartalmazó tárgylemezeket jéghideg lízis pufferbe [2,5 M NaCl (Sigma-Aldrich), 100 mM EDTA (Sigma-Aldrich), 10 mM Tris-HCl pH 10 (Sigma-Aldrich), 1\% Triton X100 (Molar Chemicals), 0,5\% N-lauroylsarcosine sodium salt (Sigma-Aldrich)] helyeztük, és $4{ }^{\circ} \mathrm{C}$-on 1,5 órát inkubáltuk őket, hogy eltávolítsuk a sejtmembránt és a fehérjéket. Az inkubációs idő eltelte után a tárgylemezeket háromszor 5 percig neutralizáló oldattal [400 mM Tris-HCl pH 7.4 (Sigma-Aldrich) és PBS] mostuk, az esetleges sejttörmelék és a lízis puffer eltávolítása érdekében. Ezt követően a tárgylemezeket jéghideg elektroforetikus pufferrel [300 mM NaOH, 1 mM EDTA, pH 13] feltöltött kádba helyeztük és 40 percig inkubáltuk benne, hogy az egyes-szálú DNS kihurkolódhasson. Ezt követően végrehajtottuk 
a minták elektroforézisét $1 \mathrm{~V} / \mathrm{cm}(25 \mathrm{~V}, 300 \mathrm{~mA})$ feszültséggel, 20 percen keresztül. A tárgylemezeket háromszor mostuk neutralizáló pufferrel és kétszer PBS pufferrel. A háttér festődés csökkentése érdekében a tárgylemezeket 1\% BSA-PBST pufferben szobahőmérsékleten 15 percig blokkoltuk, majd 1\% BSA-PBST pufferben oldott specifikus elsődleges antitesttel $4{ }^{\circ} \mathrm{C}$-on, 1,5 órán át tároltuk, végül fluorofórral konjugált másodlagos ellenanyaggal a mintákat fedőlemez alatt, nedves kamrában 1 órát inkubáltuk. A felhasznált antitestek listáját a 10. táblázat tartalmazza. Az immunfestés végén a mintákat PBS pufferrel mostuk, majd Zeiss, Axioscope fluoreszcens mikroszkóppal vizsgáltuk. Minden egyes kezelés esetében a mintáknál azonos expozíciós időt alkalmaztunk. A kapott fluoreszcens képeket Komet 5.0 image analysis szoftverrel (Kinetic Imaging Ltd., Liverpool, UK) értékeltük ki. A DNS fragmentáltságát a comet fejének (nukleusz) és farkának (károsodott DNS) fluoreszcencia intenzitásbeli különbségéből számoltuk ki, mintánként 100 véletlenszerüen kiválasztott sejt felhasználásával.

\begin{tabular}{|l|l|l|l|l|l|}
\hline \multicolumn{2}{|l|}{ Elsődleges ellenanyag } & \multicolumn{3}{l|}{ Másodlagos ellenanyag } \\
\hline Specifitása & Hígítása & $\begin{array}{l}\text { Gyártó és kat. } \\
\text { száma }\end{array}$ & Specifitása & Hígítása & $\begin{array}{l}\text { Gyártó és kat. } \\
\text { száma }\end{array}$ \\
\hline anti-BrdU & $300 x$ & $\begin{array}{l}\text { Ab-Direct } \\
\text { Serotech, V061 }\end{array}$ & $\begin{array}{l}\text { GAR Alexa } \\
488\end{array}$ & $600 x$ & $\begin{array}{l}\text { Thermo Fisher } \\
\text { S., A-11006 }\end{array}$ \\
\hline
\end{tabular}

10. táblázat: A Comet-esszé során alkalmazott ellenanyagok. A táblázatban szereplő rövidítések a rövidítések jegyzékében találhatók.

\subsection{3. siRNS csendesítés}

Az SPB10 gén csendesítésére SPB10 siRNS pool-t (L-019923-02-0005, Dharmacon) alkalmaztunk. Minden kísérlet alkalmával ún. nem kódoló (SCR) (D-001810-10-05,

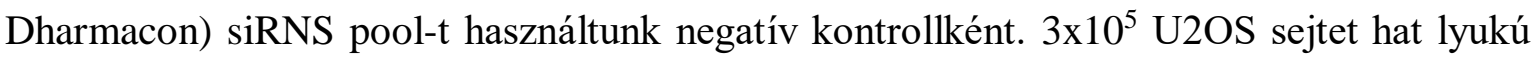
sejttenyésztő edényben növesztettünk, majd transzfektáltuk öket SPB10 esetében $40 \mu \mathrm{M}$, míg SCR esetében $5 \mu \mathrm{M}$ siRNS-sel. A kísérletekhez INTERFERin (Polyplus) transzfekciós reagenst használtunk a gyártó elöírásainak megfelelően. A transzfekciót követően a sejteket 48 óráig $37{ }^{\circ} \mathrm{C}-o s \mathrm{CO}_{2}$ inkubátorban tároltuk, antibiotikumot nem tartalmazó sejtkultúra médiumban (minden sejtvonal esetében a saját tápoldatát alkalmazva, mely a sejtek fenntartása címü fejezetben megtalálható). 


\section{Kísérleti eredmények}

\subsection{Microarray eredmények UV kezelt Hker E6SFM sejteken}

Az UV sugárzás, mint mindennapjainkat érintő környezeti faktor, és az általa kiváltott DNS károsodások, illetve ezekre adott sejtválasz egy napjainkban intenzíven tanulmányozott terület, hiszen a nem tökéletesen, vagy nem megfelelő sebességgel kijavított hibák tumoros folyamatok elindulásához vezethetnek. Kutatócsoportunkban nemrégiben egy immortalizált keratinocita, a Hker E6SFM UV sugárzásra adott génexpresszió változásait vizsgáltuk ${ }^{177}$. Microarray kísérlettel Hker E6SFM kezeletlen és UV sugárzással kezelt sejtek mRNS profilját hasonlítottuk össze. Az adatok elemzése alapján 244 gén mutatott szignifikáns expresszió változást UV kezelés hatására. Ezen gének túlnyomó többségénél, pontosan 223 esetben, a relatív expresszió értékének csökkenését tapasztaltuk. Csupán 21 gén mRNS szintjében mutattunk ki növekedést a kezelés hatására.

Az UV kezelés hatására emelkedett transzkripciós aktivitású gének közül kimutattunk egy olyan fehérjecsalád néhány tagját, mely szerepét korábban még nem vizsgálták az UV kiváltotta sejtválaszban. Ezen gének a SerpinB2, mely 2,233 a SerpinB10, mely 18,08, valamint a SerpinB13, mely 1,39-szeres expresszió növekedést mutattak UV kezelés hatására (10. ábra). Ezen eredmények arra utalhatnak, hogy a SerpinB fehérjecsalád több tagjának is szerepe lehet az UV kiváltotta sejtválaszban Hker E6SFM sejtvonalban. Ezért a továbbiakban a két legerősebb változást mutató gén a SerpinB2 (SPB2) és SerpinB10 (SPB10) vizsgálatával foglalkoztunk. 


\begin{tabular}{c|c|c|c} 
Gén & $\begin{array}{c}\text { relatív változás } \\
(\log )\end{array}$ & \multicolumn{1}{c}{ Gén } & $\begin{array}{c}\text { relatív változás } \\
(\log 2)\end{array}$ \\
\hline AGT & nem változik & SERPINB2 & 1,495 \\
SERPINA1 & nem változik & SERPINB5 & nem változik \\
SERPINA10 & nem változik & SERPINB9 & nem változik \\
SERPINA11 & nem változik & SERPINB10 & 4,253 \\
SERPINA12 & nem változik & SERPINB13 & 1,180 \\
SERPINA13 & nem változik & SERPINC1 & nem változik \\
SERPINA2 & nem változik & SERPIND1 & nem változik \\
SERPINA4 & nem változik & SERPINF2 & nem változik \\
SERPINA5 & nem változik & SERPINF3 & nem változik \\
SERPINA6 & nem változik & SERPING1 & nem változik \\
SERPINA9 & nem változik & SERPINH1 & nem változik
\end{tabular}

10. ábra: A Serpin fehérjecsalád néhány tagjának génexpresszió változása UV sugárzás hatására $\left(80 \mathrm{~mJ} / \mathrm{cm}^{2}\right)$ :

Hker E6SFM sejteken végzett microarray kísérletből származó relatív génexpresszió változások értéke log2-ben meghatározva.

\subsection{Különböző koncentrációjú, illetve erősségü DNS károsító ágensek félletális} dózisának meghatározása

A kísérleteink során olyan intenzitású stresszhatást alkalmaztunk, ami a lehető legnagyobb válaszreakcióra serkenti a sejteket anélkül, hogy a többségüket elpusztítaná. Ezért minden új kísérleti elem bevezetése előtt meghatároztuk az adott sejtvonal, bizonyos stresszhatásra mutatott félletális $\left(\mathrm{LD}_{50}\right)$ dózisát. A laboratóriumunkban az UV LD 50 értéket Hker E6SFM $\left(80 \mathrm{~mJ} / \mathrm{cm}^{2}\right.$, ) HaCaT $\left(80 \mathrm{~mJ} / \mathrm{cm}^{2}\right)$, illetve U2OS $\left(16 \mathrm{~mJ} / \mathrm{cm}^{2}\right)$ és U2OS17 $\left(16 \mathrm{~mJ} / \mathrm{cm}^{2}\right)$ sejtvonalak felhasználásával már korábban meghatározták, míg az A375 sejtekben ezt az értéket tripánkék festéssel állapítottuk meg. Az A375 sejteknél tapasztalt túlélési arány hisztogramját a 11. ábra szemlélteti, melyből megállapítható, hogy a $80 \mathrm{~mJ} / \mathrm{cm}^{2}$ erősségü sugárzást élte túl a sejtek 50\%-a. 


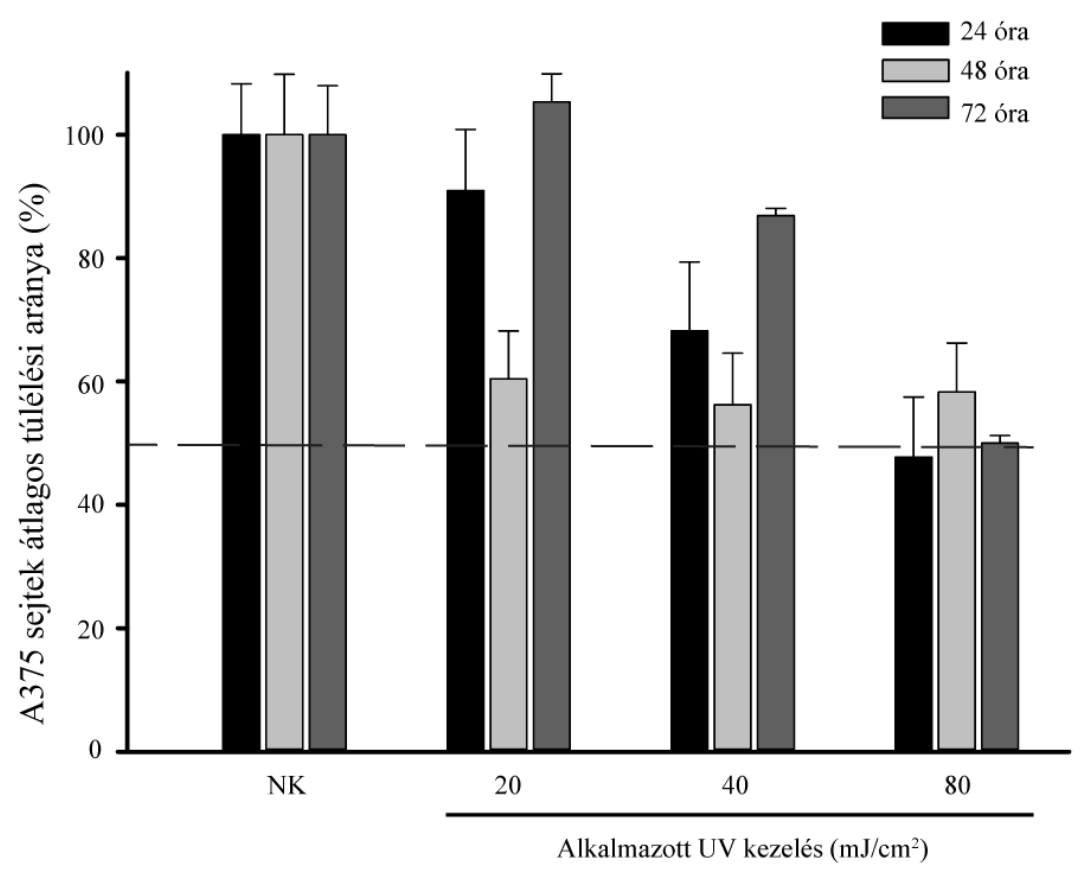

\section{1. ábra: Különböző erősségú UV sugárzás hatása A375 sejtek túlélésére:}

Az A375 sejteket 20, 40 és $80 \mathrm{~mJ} / \mathrm{cm}^{2}$ erősségü UV sugárzással kezeltük, majd tripánkék festék segítségével vizsgáltuk a sejtek túlélését 24, 48 és 72 órát követően. A szaggatott vonal az LD50 értéket jelöli.

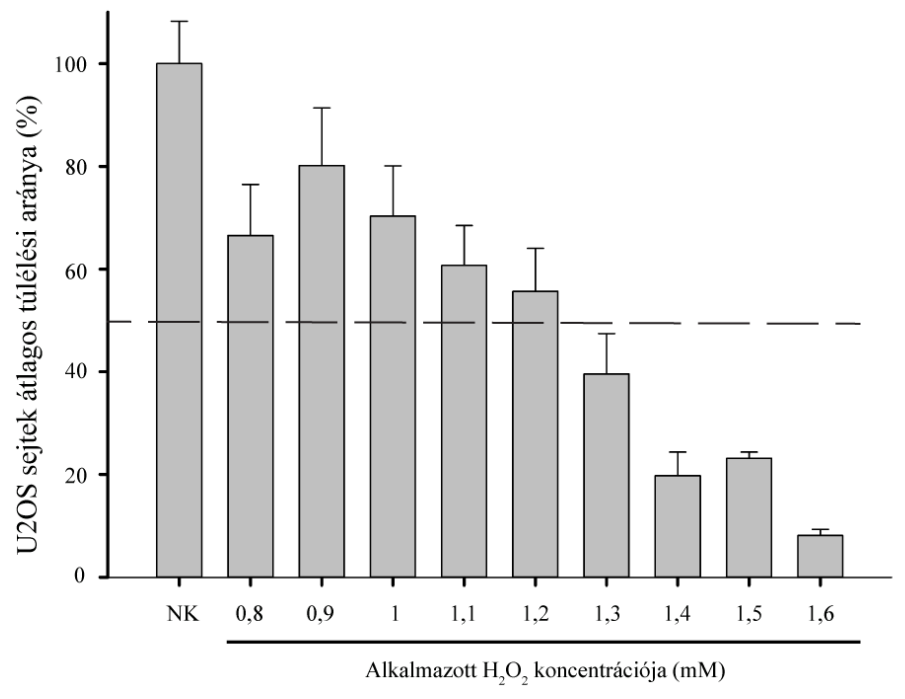

\section{2. ábra: Különböző koncentrációjú $\mathrm{H}_{2} \mathrm{O}_{2}$ kezelés hatása U2OS sejtek túlélésére:}

A U2OS sejteket 0,$8 ; 0,9 ; 1 ; 1,1 ; 1,2 ; 1,3 ; 1,4 ; 1,5$ és $1,6 \mathrm{mM}$ koncentrációjú $\mathrm{H}_{2} \mathrm{O}_{2}$-dal kezeltük, majd kristályibolya festék segítségével vizsgáltuk a sejtek túlélését. A szaggatott vonal az LD 50 értéket jelöli. 
A későbbi kísérleteink alkalmával a $\mathrm{H}_{2} \mathrm{O}_{2}$, oxidatív stresszt kiváltó vegyület túlélést befolyásoló hatását is vizsgáltuk és U2OS sejteken kristályibolya festék használatával meghatároztuk az $\mathrm{LD}_{50}$ értéket. Az túlélési görbe hisztogramját a 12. ábra szemlélteti. Méréseink azt mutatták, hogy 1,2 mM koncentrációjú $\mathrm{H}_{2} \mathrm{O}_{2}$ kezelést a sejtek körülbelül 55\% éli túl míg, ha 1,3 mM-t alkalmaztunk, csak 39,5\% túlélést tapasztaltunk, így a további kísérletekben az 1,25 mM koncentrációjú $\mathrm{H}_{2} \mathrm{O}_{2}$ kezelést alkalmaztuk.

\subsection{SPB2 UV sugárzás hatására kialakuló sejtválaszban betöltött szerepe}

A dolgozatom elkövetkező szakaszában az SPB2 fehérje vizsgálatát célzó eredményeinket mutatom be.

\subsubsection{UV kezelés hatására az SPB2 relatív mRNS szintje megemelkedik a vizsgált sejtvonalakban}

Az elözetes eredményeink arra utaltak, hogy Hker E6SFM sejtekben a SerpinB2 szerepet játszhat az UV sugárzás kiváltotta sejtválaszban. Annak érdekében, hogy igazoljuk a

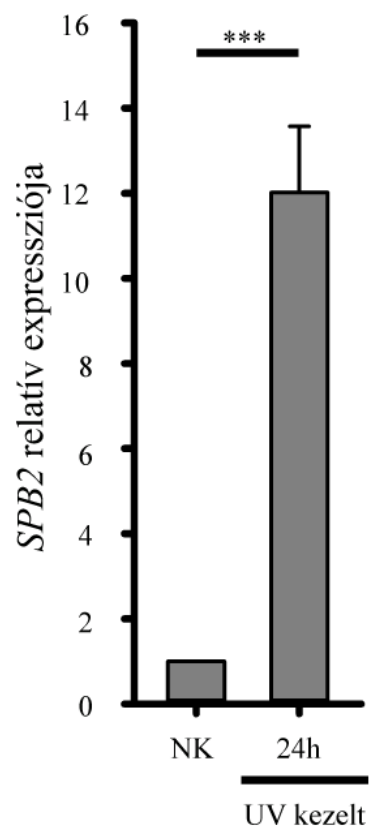

13. ábra: UV sugárzás hatására bekövetkező $S P B 2$ génexpresszió változás Hker E6SFM sejtekben:

A Hker E6SFM sejteket $80 \mathrm{~mJ} / \mathrm{cm}^{2}$ erősségü UV sugárzással kezeltük, 24 óra inkubációs időt követően qPCR módszerrel meghatároztuk az SPB2 relatív mRNS szintjét. 
korábban már részletezett microarray kísérlet eredményeit, kvantitatív real-time PCR (qPCR) módszerével vizsgáltuk az SPB2 expresszió szintjének változását Hker E6SFM kezeletlen és UV sugárzással kezelt sejtekben. Azt tapasztaltuk, hogy 24 órával az UV kezelést követően az SPB2 mRNS szintje 12-szeresére megemelkedik a kezeletlen mintához viszonyítva (13. ábra).

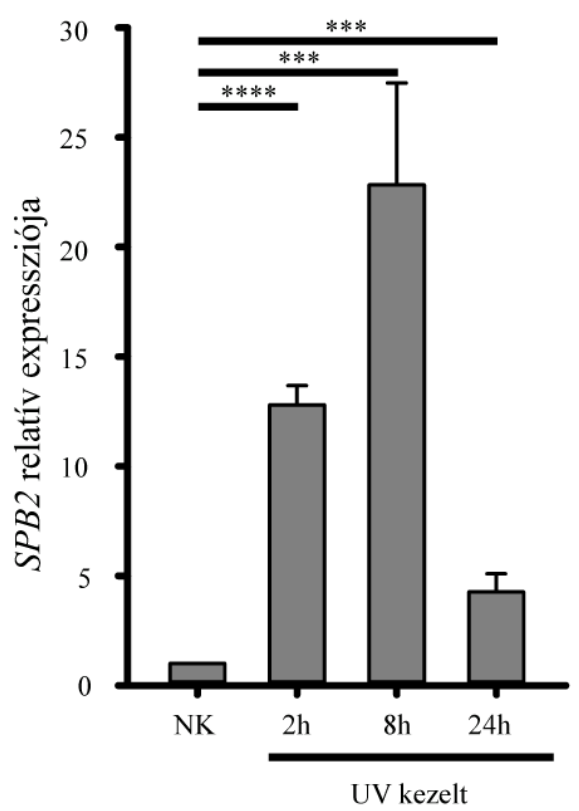

14. ábra: UV sugárzás hatására bekövetkező SPB2 génexpresszió változás A375 sejtekben:

Az A375 sejteket $80 \mathrm{~mJ} / \mathrm{cm}^{2}$ erősségű UV sugárzással kezeltük, majd 2, 8 és 24 óra inkubációs időt követően qPCR módszerrel meghatároztuk az SPB2 relatív mRNS szintjét.

Annak eldöntésére, hogy ezen jelenség csak keratinocita sejtekben játszódik le, vagy egyéb, bőrben előforduló sejtben is megfigyelhető, az SPB2 expresszió változását melanoma (A375) sejtekben is vizsgáltuk. Az eljárás során nem kezelt, valamint 2, 8 és 24 órával az UV kezelést követően mértük az SPB2 mRNS szintjét qPCR segítségével. Azt tapasztaltuk, hogy melanoma sejtek esetében is megnő az SPB2 expresszió szintje UV kezelés hatására. Az SPB2 mRNS szintje 2 órával az UV sugárzást követően már 12,8-szorosára emelkedett a kezeletlen mintához képest. Ezen expresszió érték 8 órával a kezelést követően, már 22,9szeres emelkedést mutatott. A 24 órás mintáknál csökkenni látszott ez a tendencia, de még mindig 4,3-szor magasabb mRNS értéket mértünk, mint a kezeletlen mintáknál. Tehát elmondható, hogy melanoma sejtek esetében is emelkedett az SPB2 mRNS szintje UV 
sugárzás hatására, és ábrázolva ezen értékeket egy haranggörbéhez hasonló lefutást tapasztaltunk. A kapott eredményeket a 14. ábra szemlélteti.

Következő lépésként vizsgáltuk, hogy az UV kezelés során tapasztalt SPB2 génexpresszió változás egy specifikus, csak az UV sugárzással érintkező sejtekben megfigyelhető jelenség, vagy evolúciósan konzervált folyamat, és olyan sejtvonalakban is megfigyelhető, melyek normál körülmények között nincsenek kitéve UV sugárzásnak. Ezért U2OS oszteoszarkóma sejteken is teszteltük a fentebb említett kísérleti elrendezést és qPCR mérést. A korábbiakhoz hasonlóan az UV sugárzás hatására U2OS sejtekben is emelkedett az SPB2 mRNS szintje 2, 8 és 24 órával a kezelést követően (1,8, 4,7, 2,4-szeresére). A kapott eredményeket a 15. ábra szemlélteti. Az expresszió értékeket ábrázolva hasonló lefutású kinetikát tapasztaltunk, mint melanoma sejtek esetében, azonban a U2OS sejtvonalban mért SPB2 mRNS szintemelkedés jóval alacsonyabb volt, mint a keratinocita, vagy melanoma sejteknél tapasztalt változás.

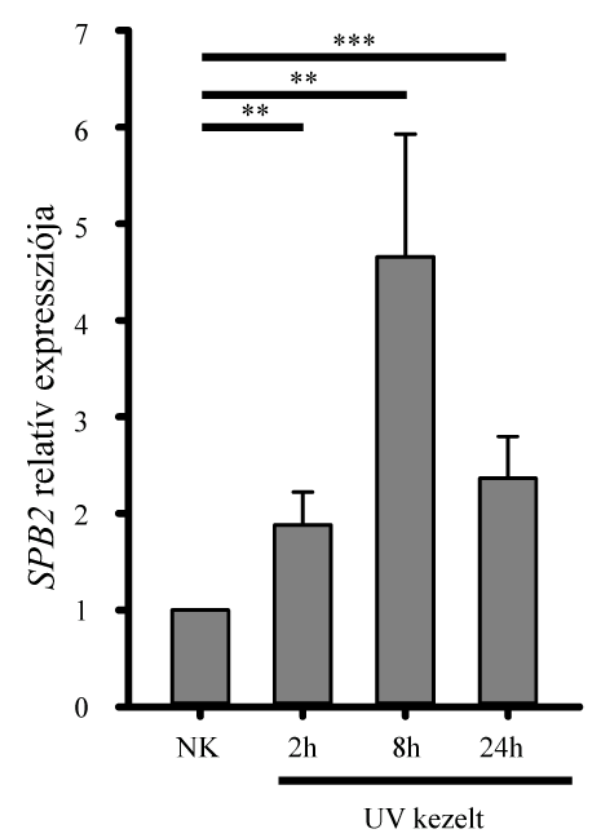

15. ábra: UV sugárzás hatására bekövetkező SPB2 génexpresszió változás mértéke U2OS sejtekben:

A U2OS sejteket $16 \mathrm{~mJ} / \mathrm{cm}^{2}$ erősségü UV sugárzással kezeltük, majd 2, 8 és 24 óra inkubációs időt követően qPCR módszerrel meghatároztuk az SPB2 relatív mRNS szintjét.

Ez magyarázható azzal, hogy ugyan az UV sugárzásra adott válasz egy konzervált folyamat, ezért számos sejtvonalnál megfigyelhető, azonban azon sejtek esetében - melyek az emberi 
test felszínén találhatók és azért alakultak ki, hogy megvédjék a szervezetünket a külső környezeti károsodásoktól- ezen sejtválasz sokkal erőteljesebb.

\subsubsection{UV kezelés hatására az SPB2 fehérje szintje megemelkedik a vizsgált sejtvonalakban}

Annak tisztázására, hogy a megfigyelt SPB2 aktiváció UV sugárzás hatására csak mRNS szinten következik be, vagy az mRNS változást SPB2 fehérje szintemelkedés is követi, Western blot technikával vizsgáltuk az SPB2 fehérje mennyiségét Hker E6SFM és A375 sejteken. Méréseink mindkét sejtvonalban hasonló eredményt mutattak: az SPB2 fehérje szintje UV sugárzás hatására megemelkedett 2, 8 és 24 óra inkubációs időt követően a nem kezelt mintákhoz képest (16. ábra).

a

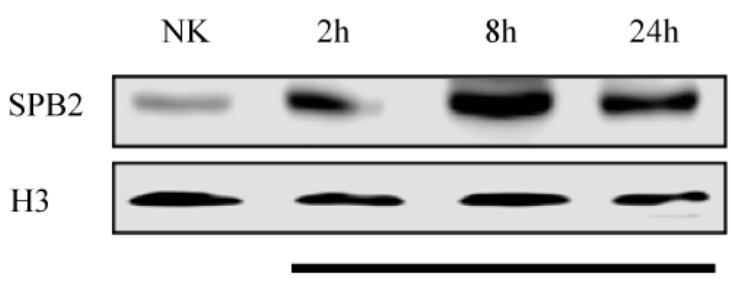

UV kezelt

b

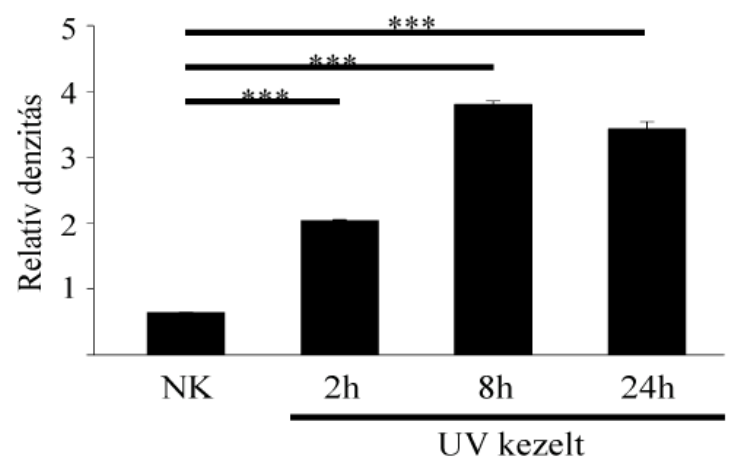

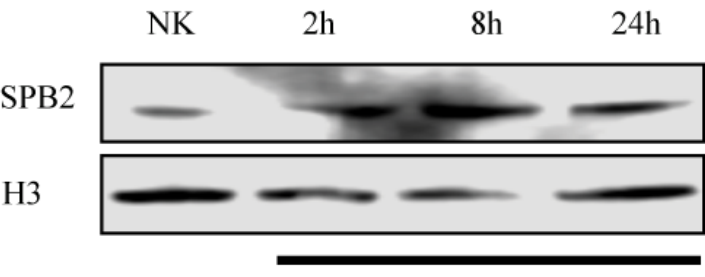

UV kezelt

d

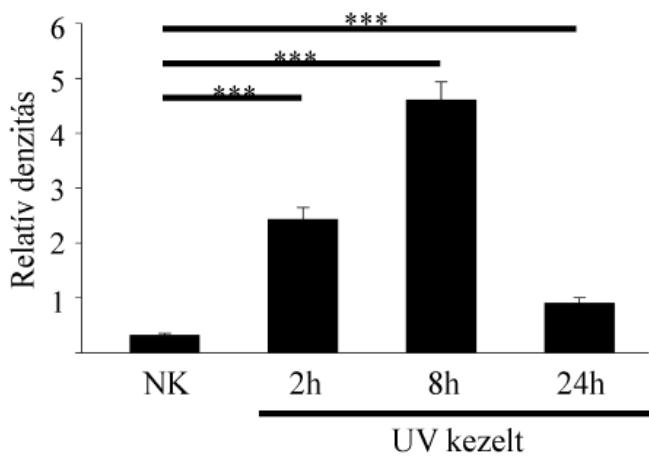

16. ábra: Hker E6SFM és A375 sejtekben bekövetkező SPB2 fehérje szintjének változása UV sugárzás hatására:

(a)A Hker E6SFM és (c) az A375 sejteket $80 \mathrm{~mJ} / \mathrm{cm}^{2}$ erősségü UV sugárzást követően 2, 8 és 24 óra inkubációs idővel összegyüjtöttük, majd a sejtekből izolált fehérjemintákon Western blot technika segítségével mértük az SPB2 fehérje szintjét. Az egyenletes mintafelvitel pozitív kontrolljaként anti-H3 ellenanyagot alkalmaztunk. A kísérletek fehérje mennyiségének kiértékelése Fiji (Image J) szoftverrel történt, melyet Hker E6SFM sejteknél a (b), míg A375 sejteknél a (d) ábra szemléltet. 
A 16. ábrán megfigyelhető, hogy az SPB 2 fehérje legmagasabb mennyiségét 8 órával a UV sugárzást követően tapasztaltuk, majd 24 órával az SPB2 szintje csökkenni kezdett. Továbbá megállapítható, hogy a tapasztalt SPB2 fehérjeszint változás a Hker E6SFM-nél kisebb, míg az A375 sejteknél jóval nagyobb mértékü volt. A tapasztalt különbség egy időbeli elcsúszás lehet, ami magyarázható a két sejtvonal típusából eredő különbségekkel. Mindazonáltal a fehérjeszint változás hasonló lefutású mintázatot mutatott, mint amit a relatív mRNS expressziójának mérésénél tapasztaltunk. Ezen eredményekből arra következtettünk, hogy az UV sugárzás az SPB2 mRNS és fehérje szintjét is befolyásolja.

\subsubsection{UV kezelés hatására az SPB2 fehérje sejten belüli elhelyezkedése megváltozik a vizsgált sejtekben}

Korábbi irodalmi adatoktól ismert, hogy az SPB2 fehérje fertőzés vagy gyulladásos folyamatok eredményeként a citoplazmában halmozódik fel ${ }^{181}$. Azonban Lee és Yerbury

DAPI

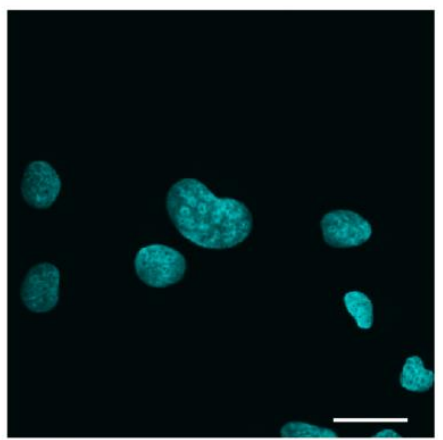

SPB2+DAPI

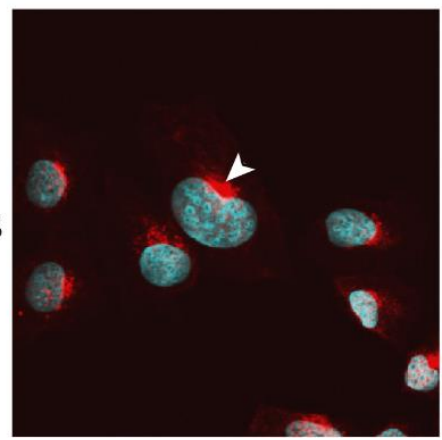

SPB2

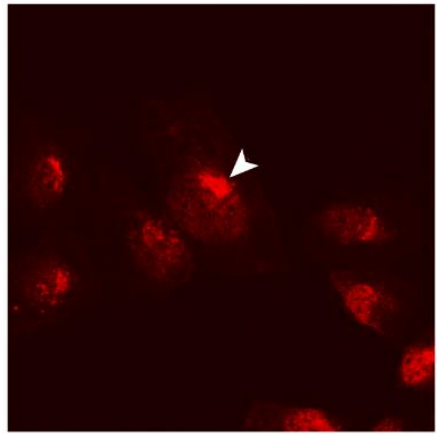

SPB2+Tubulin

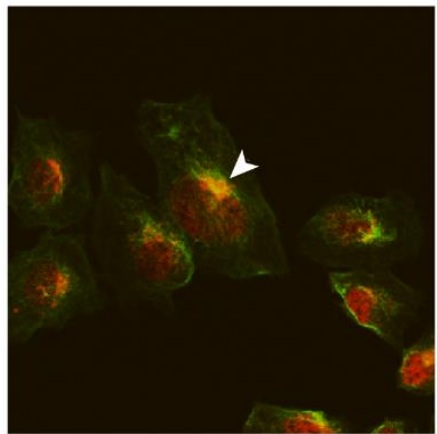

Tubulin

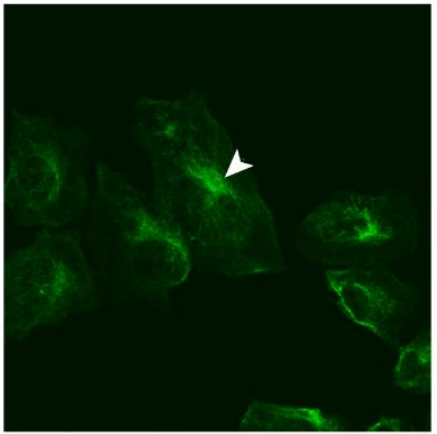

SPB2+DAPI+Tubulin

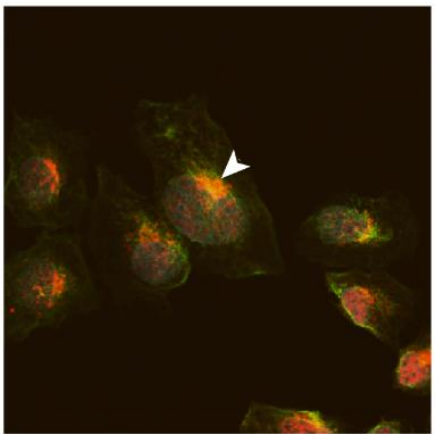

\section{7. ábra: U2OS sejtekben kimutatható az SPB2 fehérje jelenléte:}

Nem kezelt (NK) U2OS sejtekben az SPB2 fehérje (piros) lokalizációját immunhisztokémiai eljárással vizsgáltuk, míg a sejtmagokat DAPI (kék) fluoreszcens interkalálódó festék segítségével tettük láthatóvá. A citoszkeleton kimutatására antiTubulin ellenanyagot (zöld) használtunk. A nyilak a két fehérje ko-lokalizációs helyeit mutatják. A lépték $30 \mu \mathrm{m}-\mathrm{t}$ jelöl. 
kimutatták, hogy az SPB2-GFP fúziós fehérje humán, vese eredetü sejtekben mind a citoplazmában, mind a sejtmagban megfigyelhető ${ }^{182}$. Az SPB2 lokalizációjának nyomon követésére U2OS sejteket használtunk és bennük immunhisztokémiai módszerrel vizsgáltunk az SPB2 sejten belüli elhelyezkedését.

A 17. ábrán látható, hogy az SPB2 fehérje U2OS sejtekben főleg a citoplazmában található, és csak kevés festődést tapasztaltunk a sejtmagban. Számos esetben megfigyeltük, hogy a fehérje a citoplazmában, a tubulin hálózattal együtt festődik.

A szakirodalomból azt is tudjuk, hogy számos proteáz, mely normál körülmények között a citoplazmában található, stressz hatásra a sejtmagba transzportálódik. Előbbi kísérleteinkben kimutattuk, hogy az SPB2 mRNS és fehérje szintje is megemelkedik UV sugárzás hatására, ami alapján azt feltételezzük, hogy ezen Serpinnek az UV sugárzás kiváltotta sejtválaszban lehet szerepe. Mivel az SPB2 egy proteáz inhibítor család tagja, mely inhibítorok a proteázokat követve stressz hatásra a sejtmagba transzportálódhatnak, ezért megvizsgáltuk az SPB2 fehérje szubcelluláris lokalizációját UV sugárzás hatására. A kezeletlen, valamint 2 és 4 órával az UV kezelést követő U2OS sejtek szubcelluláris frakcióit elválasztottuk citoplazmatikus, nukleáris szolubilis és inszolubilis részekre, majd ezen mintákat Western blot technikával vizsgáltuk. Eredményeink azt mutatták, hogy kezeletlen U2OS sejtekben az SPB2 fehérje főleg a citoplazmában található. UV sugárzás hatására megemelkedett az SPB2 fehérje szintje, mind a citoplazmatikus, mind a nukleáris frakciókban. Azonban a kromatin nem kötött (szolubilis) és a kromatinhoz kötődő (inszolublis) sejtmagi frakciókban ezen emelkedés időben elkülönült egymástól, ugyanis 2 órával az UV kezelést követően csak a szolubilis nukleáris frakcióban láttunk emelkedést. Ezzel szemben 4 órával a kezelést követően a szolubilis frakcióban a fehérje szintje csökkenést mutat, míg az inszolubilis, azaz kromatin kötött frakcióban szintemelkedést tapasztaltunk (18. ábra).

Ezen eredményekből arra következtettünk, hogy U2OS sejtekben amellett, hogy az SPB2 fehérje szintje emelkedik UV sugárzás hatására, szubcelluláris lokalizációja is megváltozik, ugyanis a citoplazmából a sejtmagba transzportálódik, ahol 4 órával a kezelést követően már az inszolubilis, azaz kromatin kötött sejtmagi frakcióban figyelhető meg.

Eredményeinket A375 melanoma sejteken is igazoltuk, ahol 4 órával UV kezelést követően az inszolubilis nukleáris frakcióban szintén emelkedett az SPB2 fehérje szintje (19. ábra). 
Eredményeinkből arra következtettünk, hogy az UV sugárzás az idő függvényében indukálja az SPB2 fehérje nukleáris transzportját, valamint feltételezésünk szerint a sérült DNS körül a kromatinhoz való kötődését is befolyásolja.

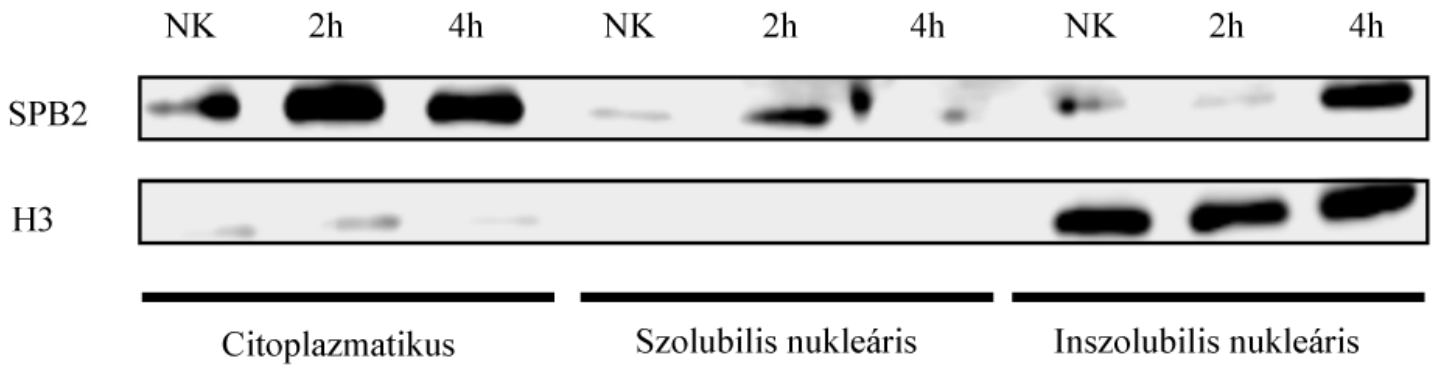

b

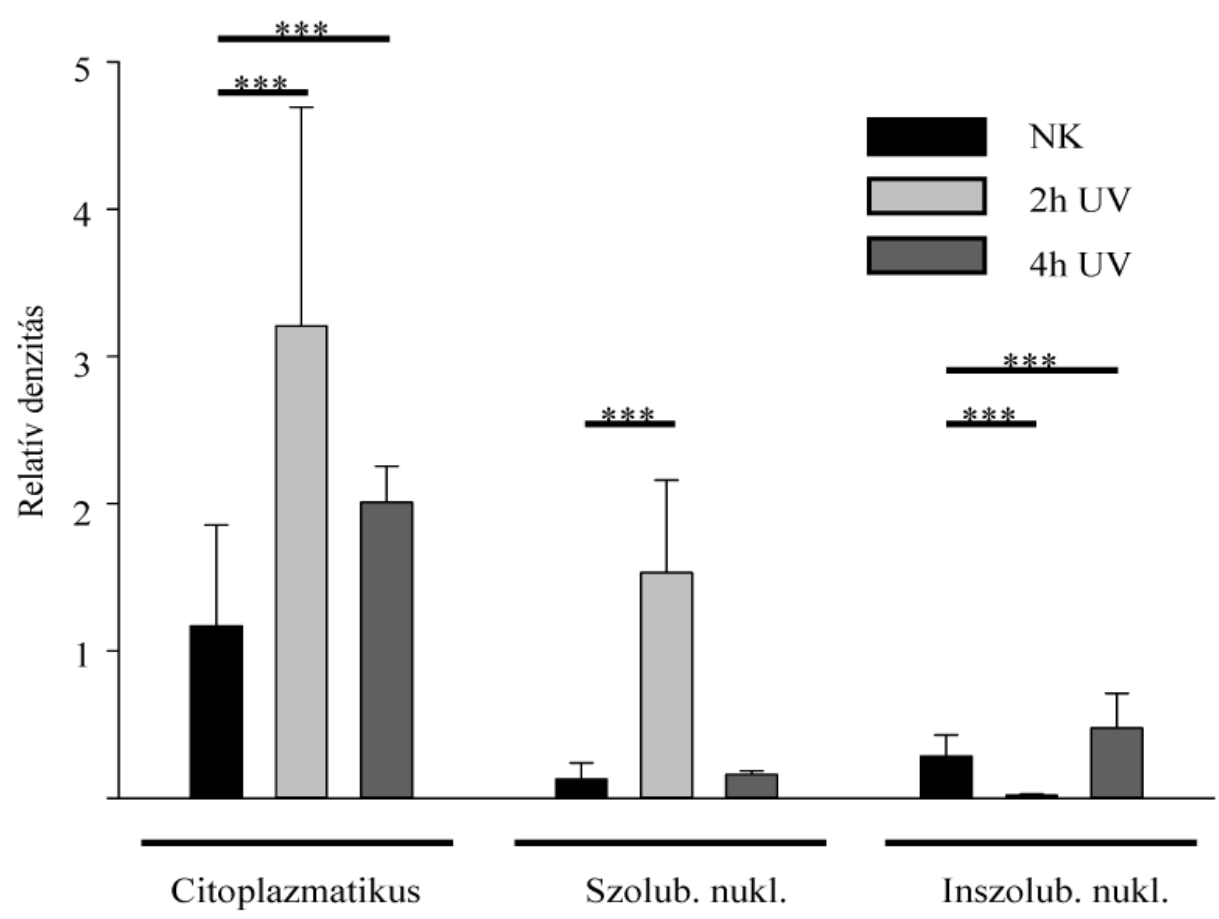

18. ábra: U2OS sejtekben történő SPB2 fehérje szintjének és lokalizációjának vizsgálata UV kezelést követően:

(a) U2OS sejteket 2 és 4 órával a $16 \mathrm{~mJ} / \mathrm{cm}^{2}$ erősségü UV sugárzást követően összegyüjtöttük, majd a fehérjemintákat frakciókra bontottuk (citoplazmatikus, sejtmagi szolubilis és inszolubilis) és ezt követően Western blot technika segítségével detektáltuk az SPB2 fehérje szintjét. Az inszolubilis sejtmagi frakció elkülönítésének és egyenletes mintafelvitel igazolásához anti-H3 ellenanyagot használtunk. A kísérletben az azonosított fehérje mennyiségek kvantitatív kiértékelése Fiji (Image J) szoftver segítségével történt, melyet a (b) ábra szemléltet. 
a

$\begin{array}{lllllllll}\text { NK } & 2 \mathrm{~h} & 4 \mathrm{~h} & \mathrm{NK} & 2 \mathrm{~h} & 4 \mathrm{~h} & \mathrm{NK} & 2 \mathrm{~h} & 4 \mathrm{~h}\end{array}$

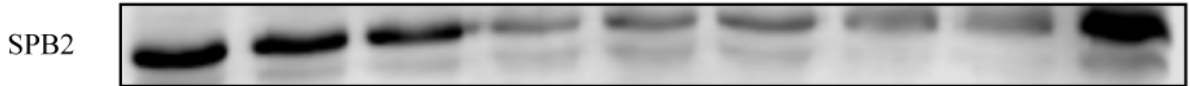

$\mathrm{H} 3$
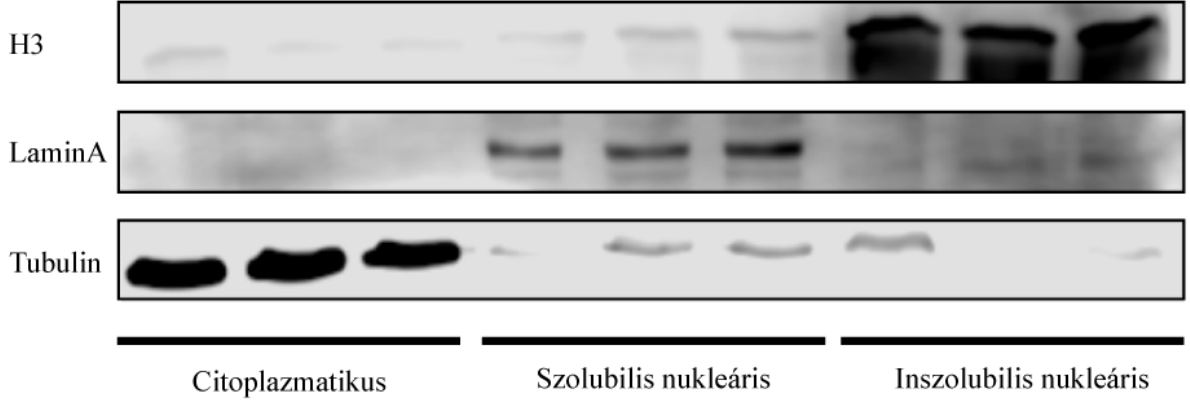

b

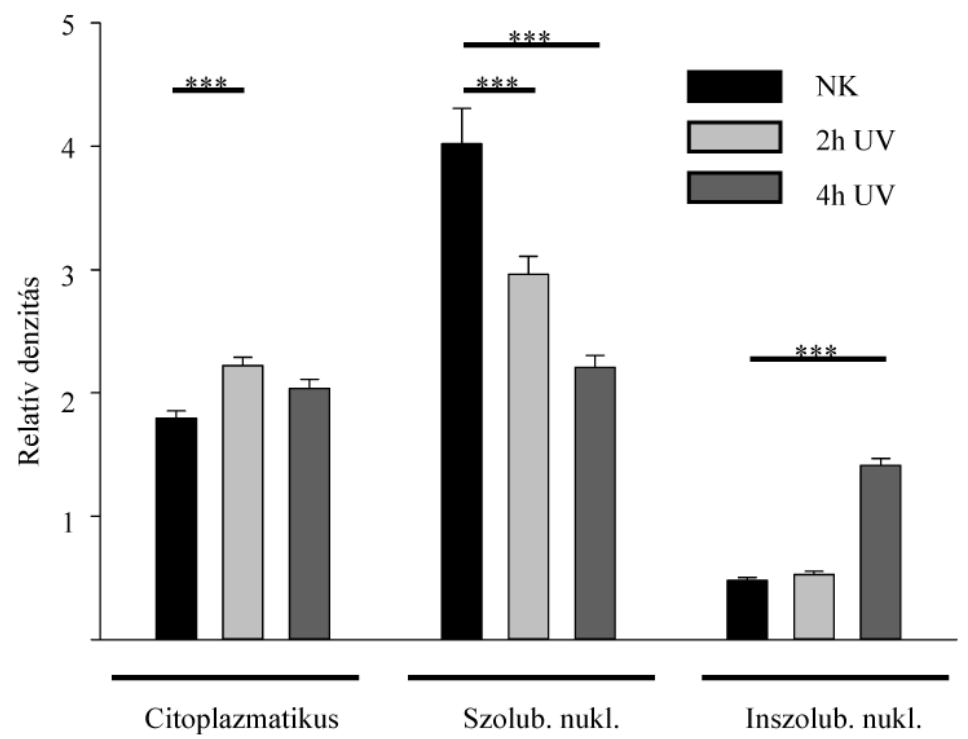

19. ábra: Az SPB2 fehérje szintjének és lokalizációjának változása A375 sejtekben UV kezelést követően:

(a) A375 sejteket 2 és 4 órával a $80 \mathrm{~mJ} / \mathrm{cm}^{2}$ erősségű UV sugárzást követően összegyüjtöttük, majd a fehérjemintákat frakciókra bontottuk (citoplazmatikus, nukleáris szolubilis és nukleáris inszolubilis) és ezt követően Western blot technika segítségével detektáltuk az SPB2 fehérje szintjét. Annak bemutatására, hogy az egyes frakciók csak az előzetes várakozásainknak megfelelő fehérjéket tartalmazzák, a következő ellenanyagokat használtuk: anti-H3 (inszolubilis nukleáris), anti-LaminA (szolubilis nukleáris) és antiTubulin (citoplazmatikus). A kísérletben detektált fehérje mennyiségének kvantitatív kiértékelése Fiji (Image J) szoftverrel történt, melyet a (b) ábra szemléltet. 


\subsubsection{Különbözö stresszhatások következtében az SPB2 fehérje fókuszokat alakít ki a sejtmagban}

Az SPB2 kromatin kötött állapotának igazolására CSK-immunhisztokémiát alkalmaztunk, melynek során eltávolítottuk a citoplazmatikus, valamint a DNS-hez nem kötött sejtmagi fehérjéket. Erre az eljárásra azért is szükség volt, hogy a korábban tapasztalt nagy mennyiségü citoplazmatikus SPB2 fehérje jelenléte ne befolyásolja a sejtmagban található SPB2 kimutatási hatékonyságát. Munkánk során a kezeletlen, valamint 2 és 4 órával az UV kezelést követően U2OS sejtekben immunhisztokémiai módszerrel detektáltuk az SPB2 sejtmagon belüli elhelyezkedését. Eredményeink igazolták, hogy 2 és 4 órával az UV kezelést követően a kromatin kötött SPB2 fehérje szintje szignifikánsan megemelkedik, illetve az SPB2 fókuszokat alakít ki a sejtmagban, mely utalhat a fehérje hibajavító fókuszokban történő megjelenésére (20. ábra).

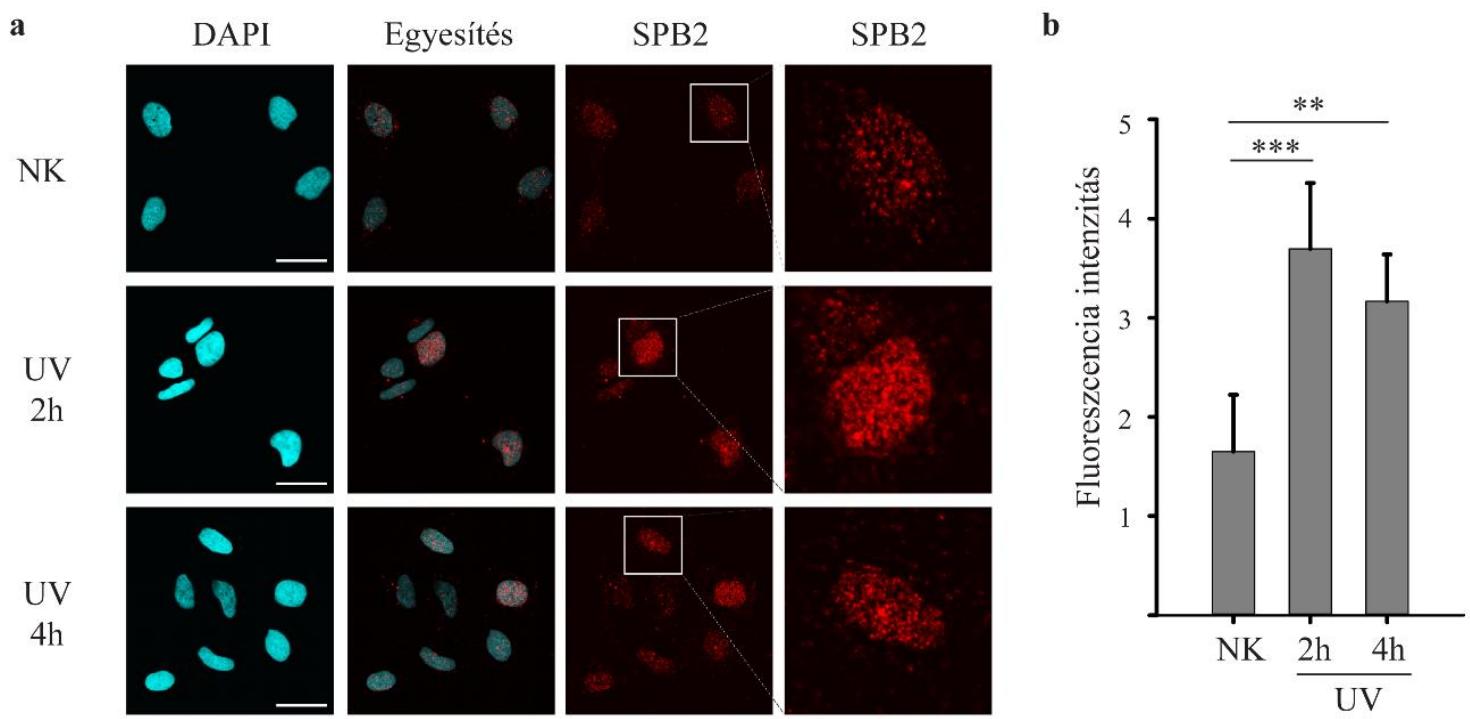

20. ábra: Az SPB2 fehérje szintjének változása UV kezelés hatására U2OS sejtek sejtmagi régiójában:

(a) Kezeletlen, valamint $16 \mathrm{~mJ} / \mathrm{cm}^{2}$ erösségü UV sugárzással kezelt U2OS sejtekben az SPB2 fehérje (piros) szintjét és lokalizációját vizsgáltuk CSK-immunhisztokémiai eljárással. A sejtmagokat DAPI (kék) fluoreszcens interkalálódó festék segítségével tettük láthatóvá. A lépték $30 \mu \mathrm{m}$-t jelöl. Az SPB2 festődés fluoreszcencia intenzitásának kvantitatív kiértékeléséhez Fiji (Image J) szoftvert használtunk, melynek eredményét a (b) ábra szemlélteti. 
Annak tisztázására, hogy ezen fókusz formáció megfigyelhetö-e különböző DNS hibákat kiváltó egyéb stresszhatások következtében, hidrogén-peroxiddal $\left(\mathrm{H}_{2} \mathrm{O}_{2}\right)$, valamint

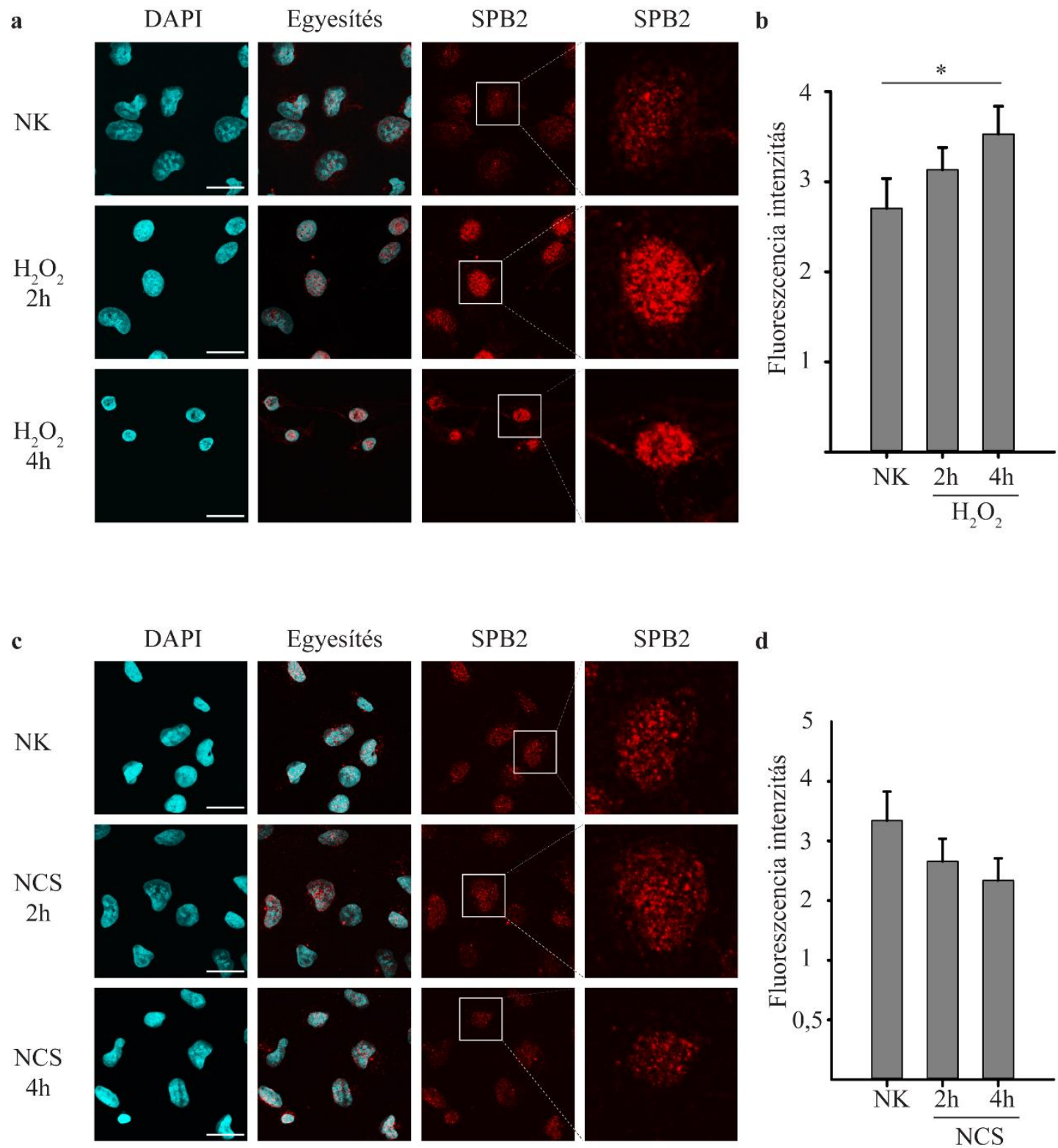

\footnotetext{
21. ábra: Az SPB2 fehérje szintjének vizsgálata $\mathrm{H}_{2} \mathrm{O}_{2}$ és NCS kezelés hatására U2OS sejtek nukleuszában:

Kezeletlen, valamint 2 és 4 órával a (a) $\mathrm{H}_{2} \mathrm{O}_{2}(1,25 \mathrm{mM})$, vagy (c) NCS (50ng/ml) kezelést követő U2OS sejtekben az SPB2 fehérje (piros) szintjét és lokalizációját vizsgáltuk CSKimmunhisztokémiai eljárással. A sejtmagokat DAPI (kék) fluoreszcens interkalálódó festék segítségével tettük láthatóvá. A lépték $30 \mu \mathrm{m}$-t jelöl. A kísérlet fluoreszcencia intenzitásának kiértékelése Fiji (Image J) szoftverrel történt, melyet $\mathrm{H}_{2} \mathrm{O}_{2}$ kezelésnél a (b) ábra, míg NCS kezelés esetében a (d) ábra szemléltet.
} 
neocarzinostatinnal (NCS) kezelt U2OS sejteken CSK-immunhisztokémiai vizsgálatot végeztünk.

Az irodalomból ismert, hogy a $\mathrm{H}_{2} \mathrm{O}_{2}$ oxidatív stressz kiváltására használható, míg az NCS egy röntgensugárzás hatását mimikáló drog, mely kettős-szálú DNS töréseket idéz elő ${ }^{183,184}$. Hasonlóan az UV sugárzáshoz, a $\mathrm{H}_{2} \mathrm{O}_{2}$ kezelést követő 2 és 4 órában az SPB2 fehérje szintje megemelkedett a kezeletlen mintákhoz képest, továbbá az UV kezeléshez hasonlóan, a $\mathrm{H}_{2} \mathrm{O}_{2}$ kezelést követően SPB2 fókusz formáció figyelhető meg a sejtmagokban (21. a és b ábra). Ezzel ellentétben az NCS kezelés hatására nem tapasztaltunk szignifikáns különbséget a fehérje mennyiségében, a kontroll mintákhoz képest (21. c és d ábra).

Annak tisztázására, hogy a kettős-szálú DNS törés hatására valóban nem történik SPB2 aktiváció, vagy esetleg más időpontokban valósul meg ez a folyamat, megismételtük az előbbi eljárást és az NCS kezelést követően immunhisztokémiai módszerrel több időpontban vizsgáltuk az SPB2 sejtmagon belüli eloszlását. Azonban továbbra sem tapasztaltunk szignifikáns SPB2 felhalmozódást a sejtmagban a kontroll mintákhoz képest, sem rövid (fél, 1 és 2 óra), sem hosszabb (6 és 24 óra) inkubációs időket alkalmazva (22. ábra).

Mindezen eredmények arra utalnak, hogy az SPB2 felhalmozódása és fókusz formációja a sejtmagban olyan stresszhatások következménye, melyekböl származó DNS hibák a nukleotidokat érintik és javításuk gyors sejtválaszt igényel. Ilyen DNS hibajavítási útvonalak lehetnek a bázis kivágó hibajavítás (BER), valamint a nukleotid kivágó hibajavítás (NER). Az irodalomból ismert, hogy azon hibák, melyek a BER által nem javítódnak ki, aktiválhatják a NER útvonalait is. Ezen megfontolásból a továbbiakban az SPB2 NER útvonalban való lehetséges szerepét tanulmányoztuk. 


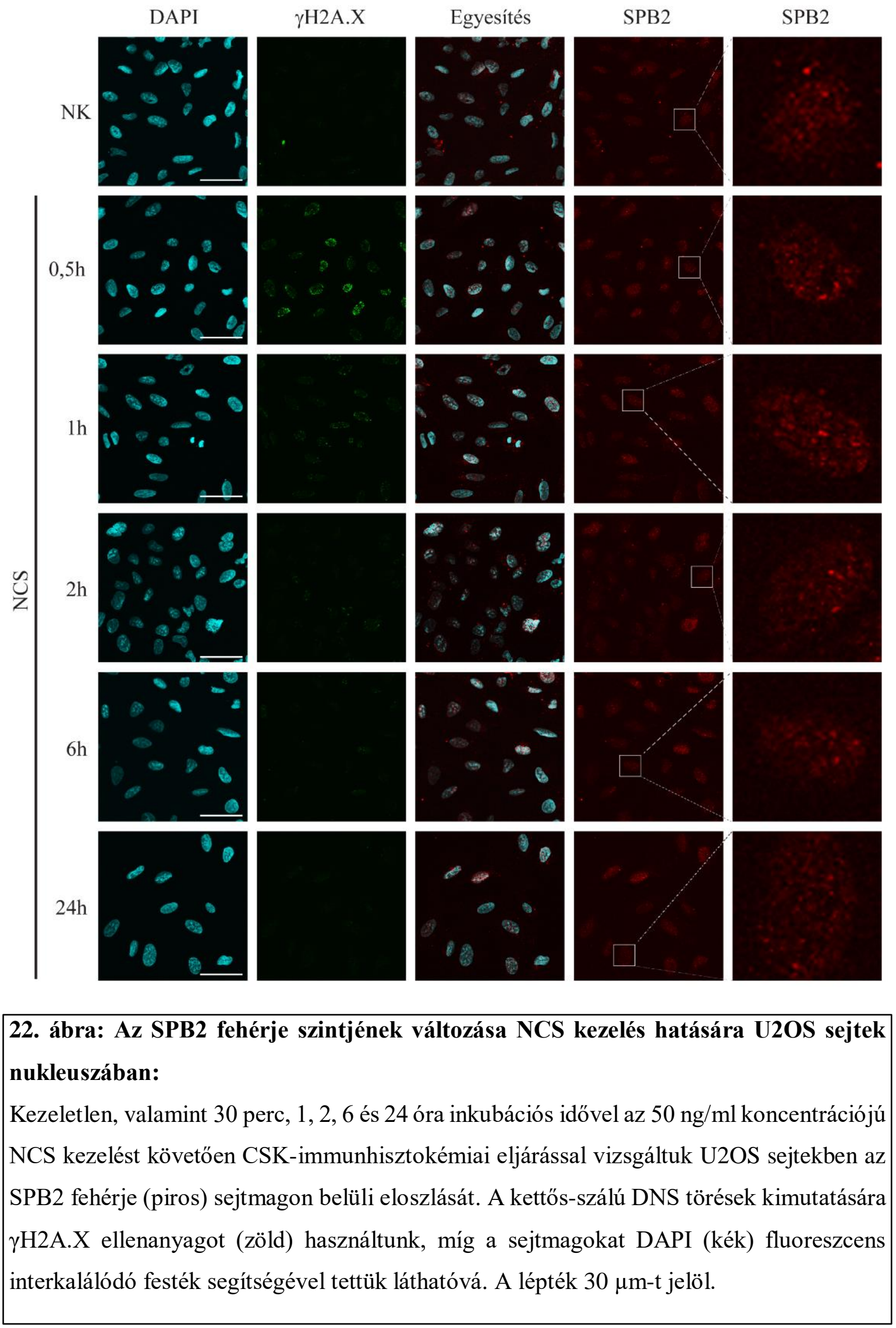




\subsubsection{Az SPB2 és a Nukleotid Kivágó Hibajavításban szerepet játszó fehérje, az XPB}

(Xeroderma pigmentosum B) együttes lokalizációja figyelhető meg UV kezelés hatására

Irodalmi adatok alapján ismeretes, hogy az UV és oxidatív stressz által előidézett nukleotid módosítások javítását a NER útvonal végzi ${ }^{17}$. Ezért előzetes eredményeinkből feltételeztük, hogy az SPB2 szerepet játszhat ezen hibajavító útvonalban. Hipotézisünk alátámasztására U2OS sejtekben 2 és 4 órával az UV kezelést követően CSK immunfestéssel vizsgáltuk az SPB2 és a NER útvonalban szerepet játszó XPC, XPB, XPF fehérjék ko-lokalizációját.

Kísérleteink során olyan XP fehérjéket választottunk ki, melyek a NER útvonal különböző fázisaiban játszanak szerepet. Törekedtünk arra, hogy ezzel a szelekcióval olyan NER-ben szereplő fehérjéket válasszunk, melyből következtethetünk, hogy az SPB2-nek a NER útvonal mely részfolyamatában lehet funkciója. Azt tapasztaltuk, hogy az SPB2 nem, vagy csak kevés fókuszban lokalizálódik együtt az útvonal korai fázisában aktív XPC-vel (23. ábra), ill. a késői fázisban müködő XPF fehérjével (24. ábra). Azonban UV kezelés hatására az XPB és az SPB2 fehérje között (szignifikánsan) gyakori ko-lokalizációt mutattunk ki (25. ábra).

Eredményeinket igazoltuk A375 melanoma sejteken is. Ezen sejtvonal esetében is azt tapasztaltuk, hogy az SPB2 nem, vagy csak kevés fókuszban lokalizálódik együtt az XPC és XPF fehérjékkel. Továbbá UV kezelés hatására az SPB2 és XPB fehérjék azonos fókuszban való előfordulása szignifikánsan megnő melanoma sejtekben is. (26. ábra).

Eredményeink azt sugallják, hogy az SPB2 részt vehet a NER útvonal középső szakaszában, ahol az XPB helikáz aktivitása révén a DNS-buborék kialakításáért felelős. Feltételezéseink szerint az SPB2 befolyásolhatja a XPB mediálta DNS széttekeredését, vagy a hibajavításban résztvevő, a DNS-sel keresztkötött fehérjék eltávolításáért felelős proteázokat gátolhatja. 


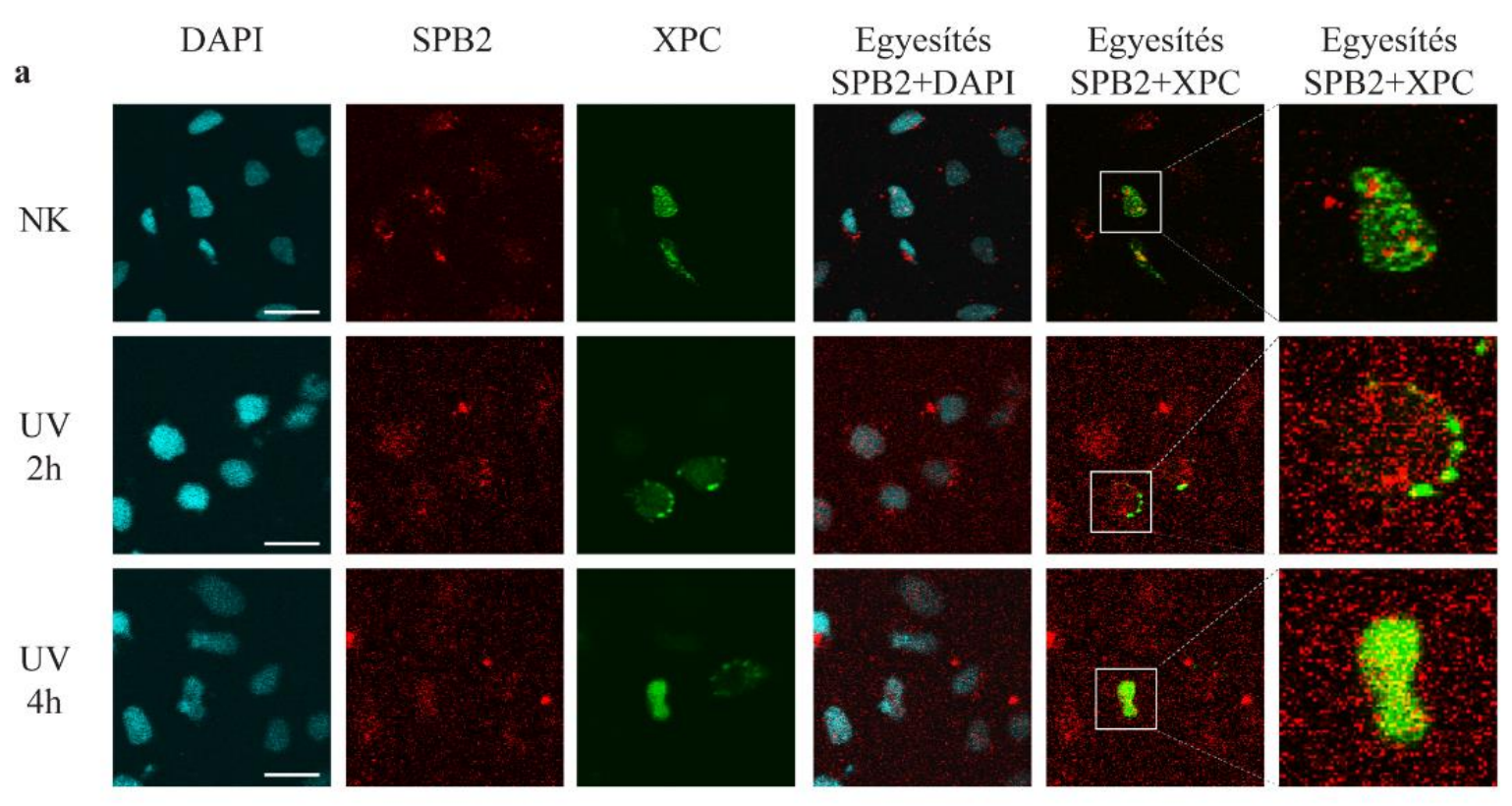

b $\quad \mathrm{XPC}-\mathrm{SPB} 2$

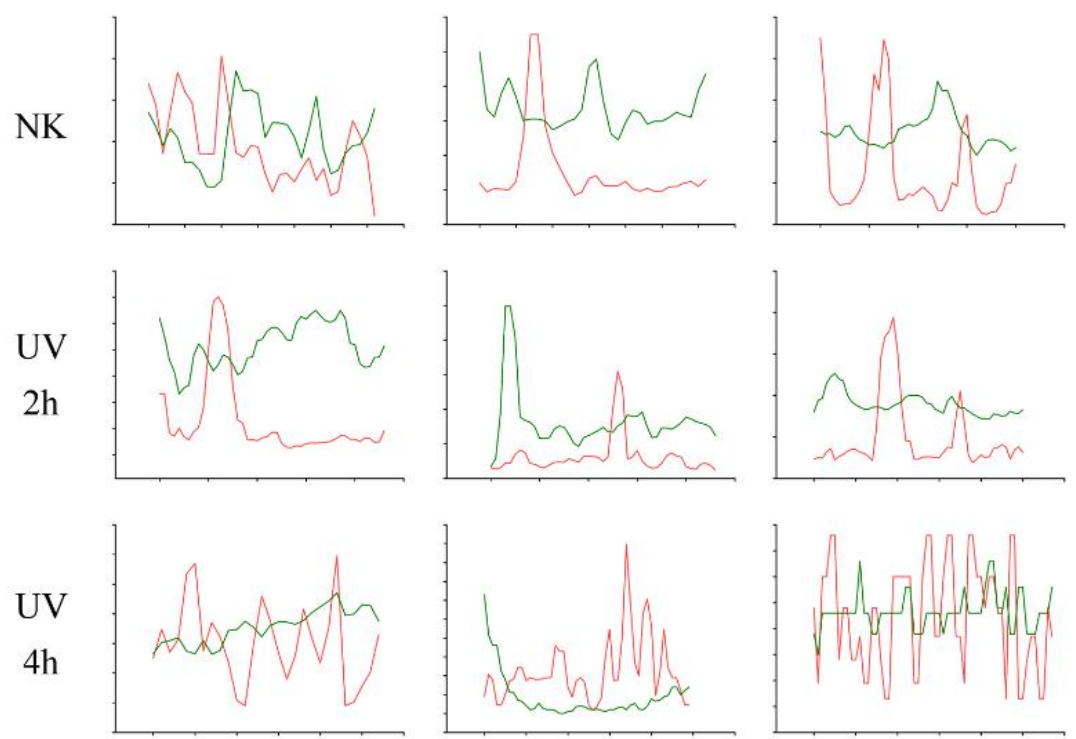

\begin{abstract}
23. ábra: Az SPB2 és az XPC hibajavító fehérje ko-lokalizációs gyakoriságának meghatározása U2OS sejtekben:

(a) Kezeletlen, valamint 2 és 4 órával a $16 \mathrm{~mJ} / \mathrm{cm}^{2}$ erősségü UV sugárzást követően vizsgáltuk U2OS sejtekben az SPB2 fehérje (piros), valamint az XPC fehérje (zöld) lokalizációját CSK-immunhisztokémiai eljárással. A sejtmagokat DAPI (kék) fluoreszcens interkalálódó festék segítségével tettük láthatóvá. A lépték $30 \mu \mathrm{m}-\mathrm{t}$ jelöl. (b) Az alkalmazott ellenanyagok fluoreszcencia intenzitásának kvantifikálása, valamint az adatokból generált grafikonok egymásra vetítésével az SPB2 (piros) és XPC (zöld) fehérjék ko-lokalizációjának ábrázolása Fiji (Image J) szoftverrel történt.
\end{abstract}




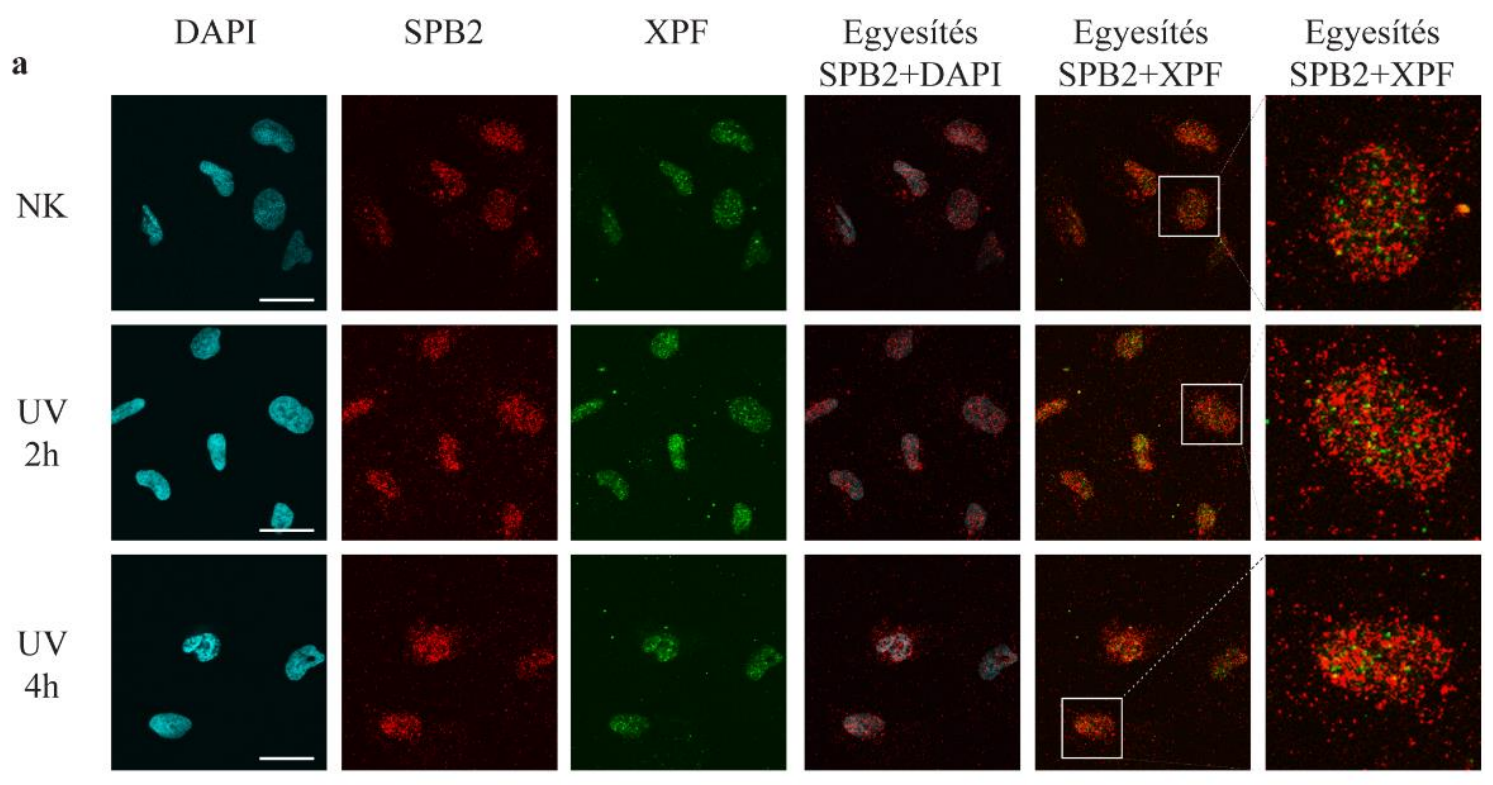

b $\quad$ XPF-SPB2
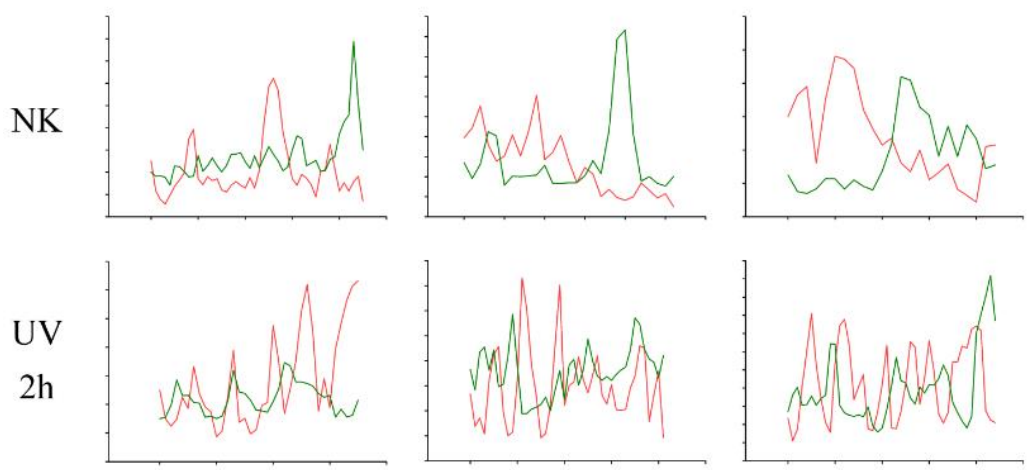

UV
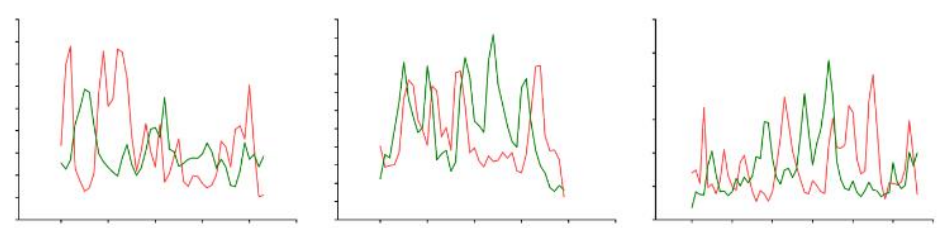

24. ábra: Az SPB2 és az XPF hibajavító fehérje ko-lokalizációs gyakoriságának meghatározása U2OS sejtekben:

(a) Kezeletlen, valamint 2 és 4 órával a $16 \mathrm{~mJ} / \mathrm{cm}^{2}$ erösségü UV sugárzást követően vizsgáltuk U2OS sejtekben az SPB2 fehérje (piros), valamint az XPF fehérje (zöld) lokalizációját CSK-immunhisztokémiai eljárással. DAPI (kék) fluoreszcens interkalálódó festék segítségével tettük láthatóvá a sejtmagokat. A lépték $30 \mu \mathrm{m}$-t jelöl. (b) Az alkalmazott ellenanyagok fluoreszcencia intenzitásának kvantifikálása, valamint az adatokból generált grafikonok egymásra vetítésével az SPB2 (piros) és XPF (zöld) fehérjék ko-lokalizációjának ábrázolása Fiji (Image J) szoftverrel történt. 


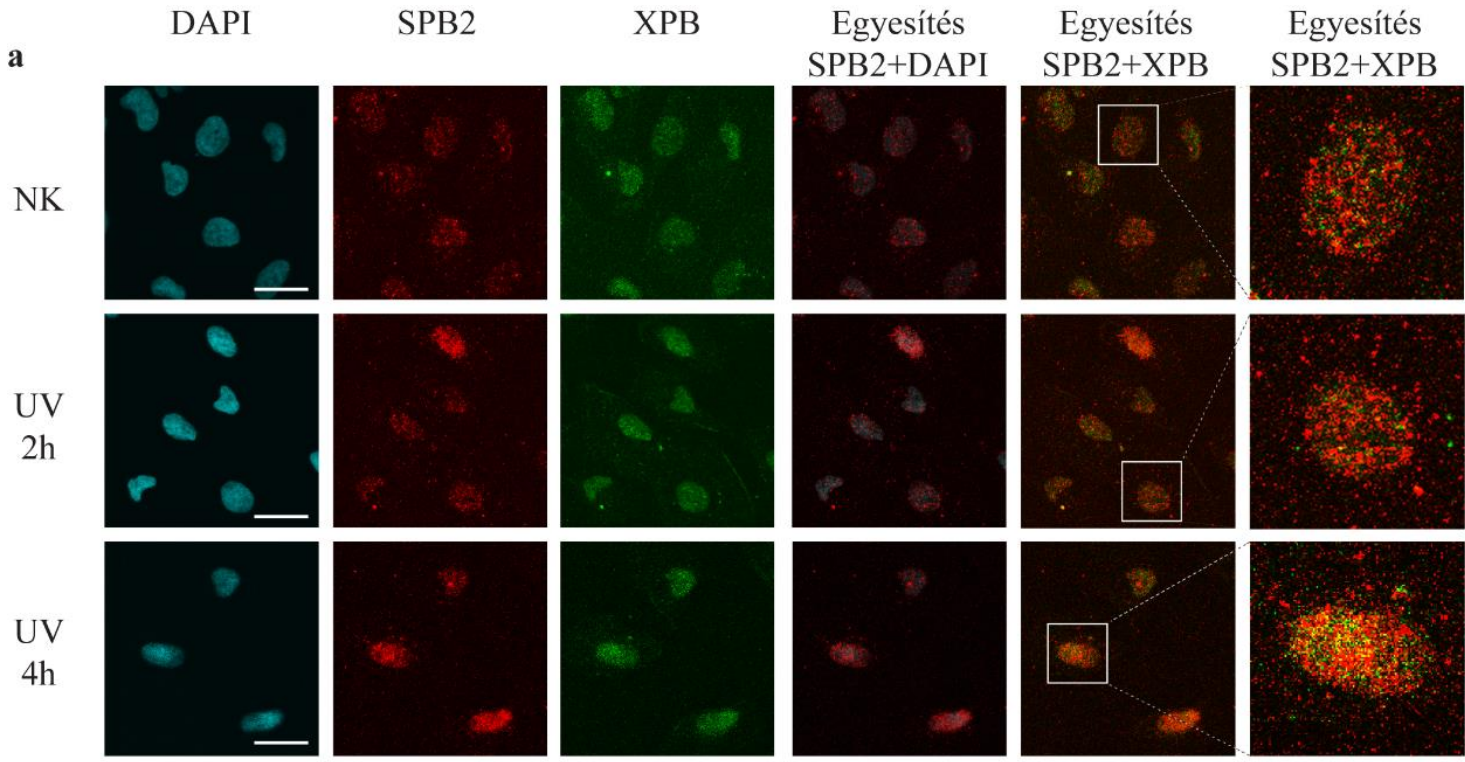

b XPB-SPB2

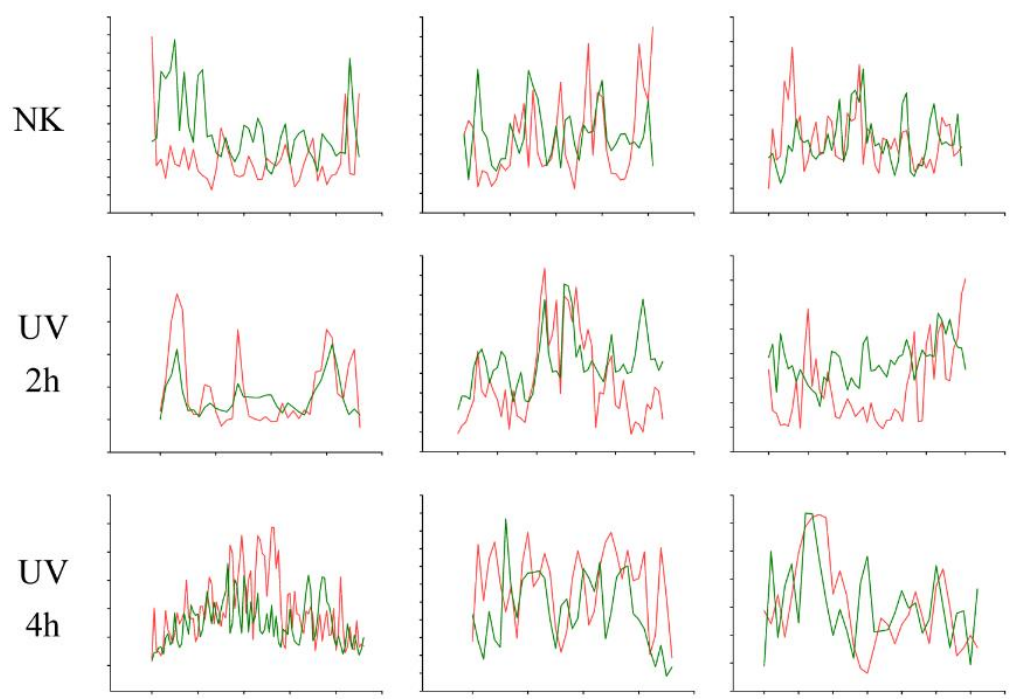

25. ábra: Az SPB2 és az XPB hibajavító fehérje ko-lokalizációs gyakoriságának meghatározása U2OS sejtekben:

(a) Kezeletlen, valamint 2 és 4 órával a $16 \mathrm{~mJ} / \mathrm{cm}^{2}$ erősségü UV sugárzást követően vizsgáltuk U2OS sejtekben az SPB2 fehérje (piros), valamint az XPB fehérje (zöld) lokalizációját CSK-immunhisztokémiai eljárással. DAPI (kék) fluoreszcens interkalálódó festék segítségével tettük láthatóvá a sejtmagokat. A lépték $30 \mu \mathrm{m}$-t jelöl. (b) Az alkalmazott ellenanyagok fluoreszcencia intenzitásának kvantifikálása, valamint az adatokból generált grafikonok egymásra vetítésével az SPB2 (piros) és XPB (zöld) fehérjék ko-lokalizációjának ábrázolása Fiji (Image J) szoftverrel történt. 


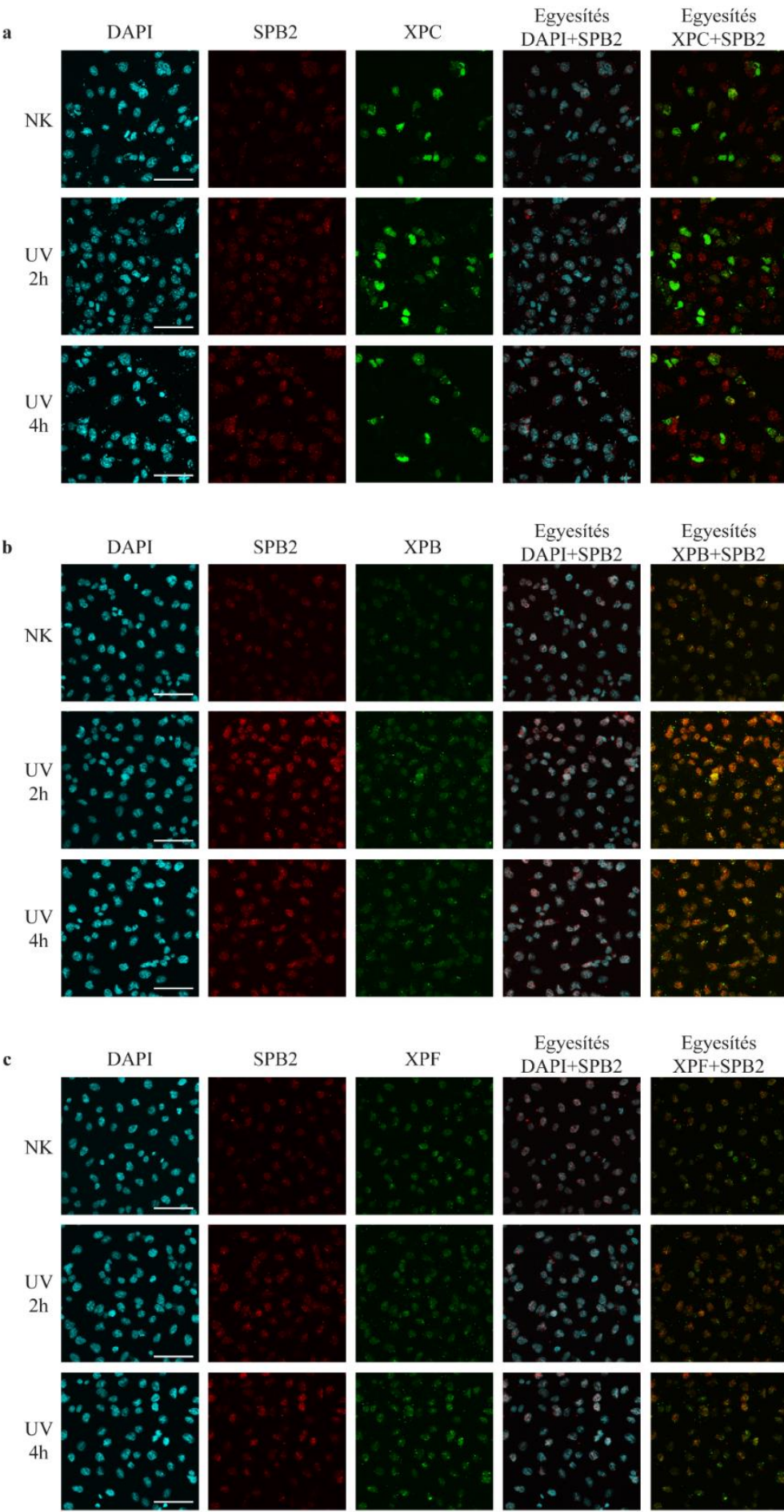

26. ábra: Az SPB2 és a NER hibajavító fehérjék ko-lokalizációs gyakoriságának meghatározása A375 sejtekben:

Kezeletlen, valamint 2 és 4 órával a $80 \mathrm{~mJ} / \mathrm{cm}^{2}$ erősségű UV sugárzást követően vizsgáltuk A375 sejtekben az SPB2 fehérje (piros), valamint az (a) XPC (zöld), (b) XPB (zöld), illetve (c) XPF fehérje (zöld) lokalizációját CSK-immunhisztokémiai eljárással. DAPI (kék) fluoreszcens interkalálódó festék segítségével tettük láthatóvá a sejtmagokat. A lépték 30 $\mu \mathrm{m}-\mathrm{t}$ jelöl. 
5.3.6. Az SPB2 és a Nukleotid Kivágó Hibajavításban szerepet játszó fehérje, az XPB (Xeroderma pigmentosum B) együttes lokalizációja ellenére a két fehérje között nem mutatható ki kölcsönhatás

Az előzőekben bemutatott eredmények arra utalhatnak, hogy UV sugárzást követően az SPB2 a NER hibajavítási fókuszokba lokalizálódik, ahol feltételezéseink szerint az XPB fehérjével lép kapcsolatba. Annak vizsgálatára, hogy ezen két fehérje között kimutatható-e kölcsönhatás, ko-immunprecipitációs (co-IP) eljárást alkalmaztunk. A kísérlet első lépéseként a U2OS sejteket SPB2-GFP fúziós fehérjét expresszáló plazmiddal transzfektáltunk. A kezeletlen, és az SPB2-GFP transzfektált UV kezelt U2OS sejteken antiGFP (green fluorescent protein) ellenanyaggal immunprecipitációs kísérletet végeztünk, majd Western blot technika segítségével, anti-XPB ellenanyag felhasználásával teszteltük a kölcsönhatást a két fehérje között, valamint az immunprecipitáció sikerességét anti-GFP ellenanyagokkal vizsgáltuk. A kísérleti eredményeket a 27. ábra szemlélteti. A Western blot kontrolljaként az immunprecipitációs eljárás során alkalmazott transzfektált U2OS sejtek lizátumából származó, ún. input minták szolgáltak, melyek képe a 27. b ábrán látható.

Az általunk használt kísérleti kondíciókkal nem tudtunk interakciót kimutatni az SPB2 és az XPB fehérjék között. Ennek okai lehetnek, hogy habár UV sugárzás hatására az SPB2 a NER hibajavító fókuszokba lokalizálódik, ahol az XPB fehérjével mutat azonos elhelyezkedést, lehetséges, hogy a két fehérje csak egy köztes interakciós partneren keresztül kapcsolódik össze. Továbbá az is előfordulhat, hogy az SPB2 és XPB fehérjék egy időben és térben fordulnak elö, de köztük nincs se fizikai, se funkcionális kapcsolat. Ennek tisztázására LacO technikát használtunk, amit a következő fejezetekben ismertetek részletesen. 
a

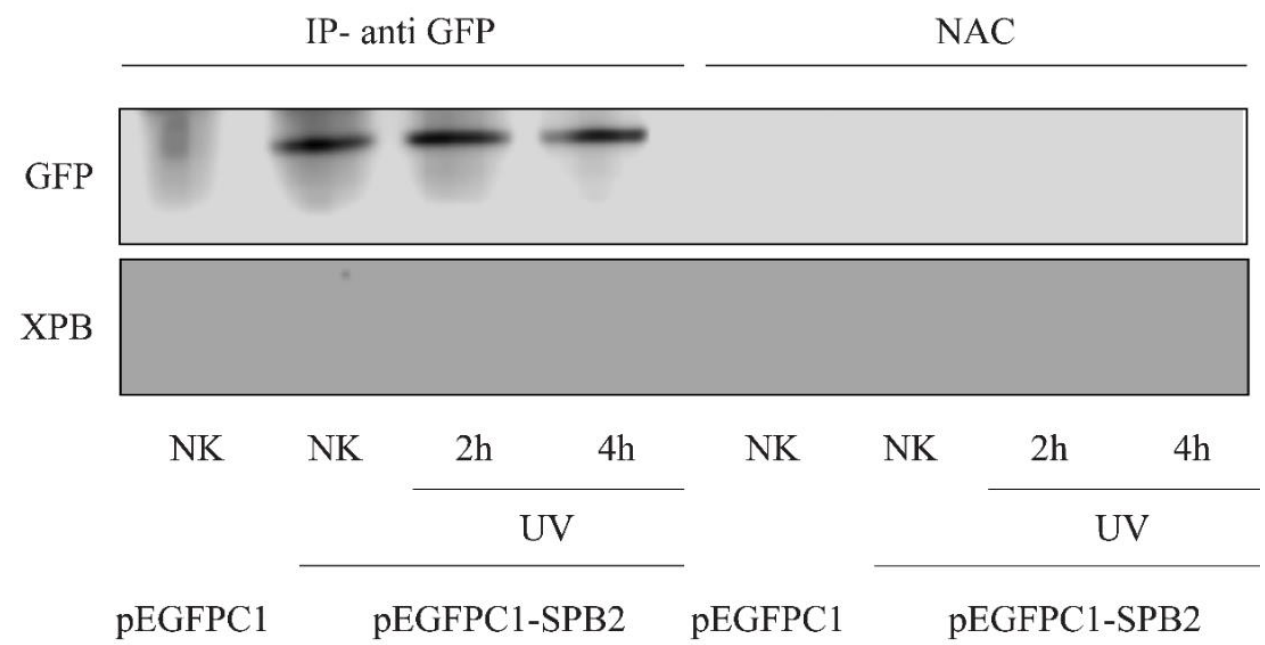

b

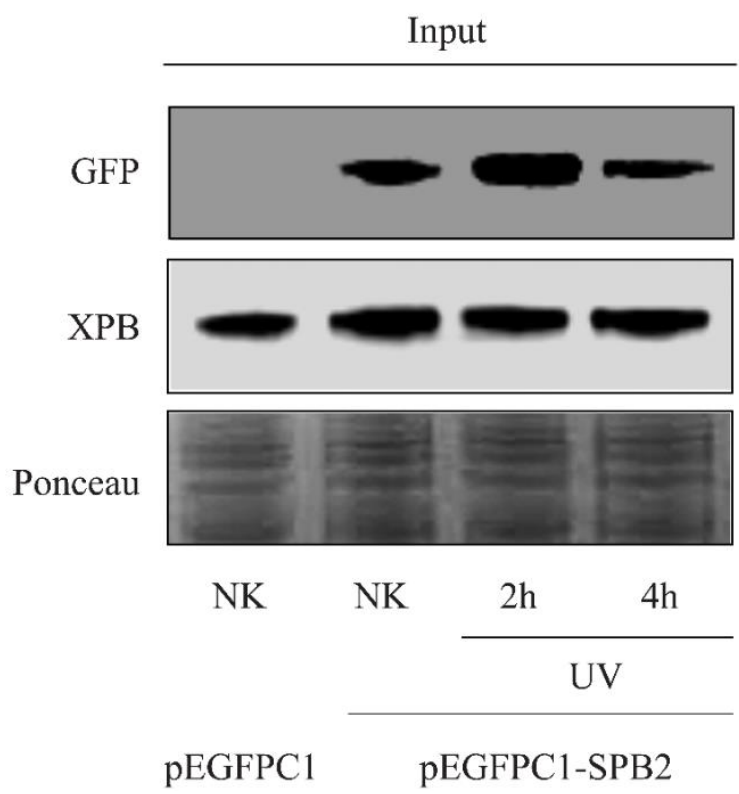

27. ábra: Az SPB2 és az XPB hibajavító fehérje köztt UV kezelés hatására létrejövő kölcsönhatás vizsgálata U2OS sejtekben:

(a) Kezeletlen, valamint 2 és 4 óra inkubációs idővel a $16 \mathrm{~mJ} / \mathrm{cm}^{2}$ erősségű UV sugárzást kezelést követően vizsgáltuk az SPB2-GFP transzfektált U2OS sejtekben az SPB2 és az XPB fehérje esetleges interakcióját ko-immunprecipitációs eljárással. Az immunprecipitációt anti-GFP antitesttel végeztük. A NAC a kísérlet negatív kontrollja (b) A ko-immunprecipitációs kísérlet input kontrollja. Az „Input” minták esetében teljes sejtlizátumban vizsgáltuk az SPB2-GFP fúziós fehérje (GFP) és az XPB protein szintjét. Az egyenletes mintafelvitelt Ponceau festéssel igazoltuk. 


\subsubsection{LacO rendszer bemutatása}

A hipotézisünk bizonyítására, hogy az immunfestésben tapasztalt SPB2-XPB kolokalizációs fókuszok megjelenése az SPB2 és az XPB funkcionális kapcsolatának lehet a jele, U2OS17 sejtekben LacO-tethering technikát használtuk. Vizsgáltuk, hogy az SPB2 UV sugárzás hatására az XPB fehérjét is magában foglaló NER hibajavítási fókuszokban jelenike meg. Ezen technika segítségével kimutathatunk olyan fehérjék közötti kapcsolatot, melyek fizikailag nem kapcsolódnak össze egymással. A LacO/LacR rendszer müködésének alapja, hogy a U2OS17 sejtek 256 specifikus LacO szekvencia ismétlődést tartalmaznak, melyeket a LacR fehérje képes felismerni és hozzákötődni. Így a LacR fehérjével fúzionáltatva képesek vagyunk specifikus proteineket kihorgonyozni bizonyos DNS régiókhoz, valamint GFP fúziós epitóppal kimutatni ezeket. Ziani Salim és munkatársai ezt a kísérleti elrendezést használva létrehoztak egy újabb rendszert, melyben az adott XP fehérje (esetünkben a GFPLacR-XPB) köthető a DNS-hez anélkül, hogy előzőleg DNS hibát idéztünk volna elő az adott DNS szekvencia környezetében. A kísérleti rendszer további előnye, hogy a kihorgonyzott fehérje képes aktiválni a NER útvonal további fehérjéinek DNS-hez való toborzását is. A kísérleti megközelítés előnye, hogy sejtekben valósul meg, továbbá nem megfordítható, azaz a kihorgonyzott XP faktor a hibajavítási útvonalban közvetlenül utána aktiválódó fehérje toborzására képes és sem az előtte, sem a folyamatban jóval később aktiválódó fehérjék nem jelennek meg az adott hibajavító fókuszban ${ }^{178,185,186}$. Ezen rendszer főbb elemeit a 28. ábra szemlélteti. Felhasználva a LacO- GFP-LacR-XPB komponenseket tartalmazó sejteket, kimutattuk, hogy az SPB2 fehérje kötődött azokban a DNS régiókban, ahová az XPB faktort kihorgonyoztuk, ezáltal igazoltuk, hogy az SPB2 és az XPB NER hibajavítási útvonal egyazon lépéseiben vesznek részt.

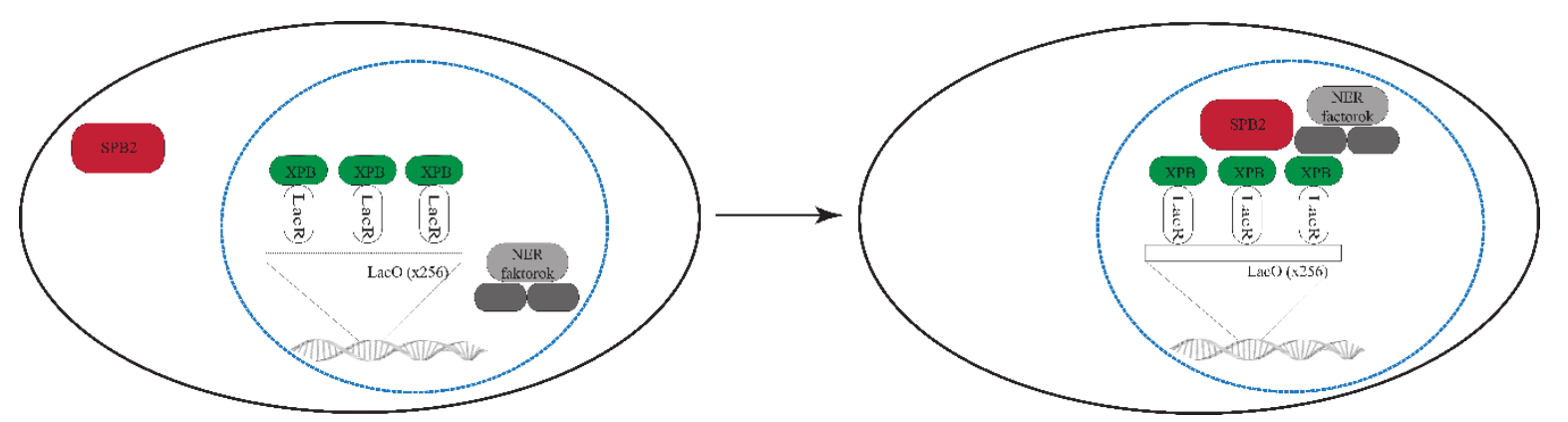

28. ábra: LacO/ LacR rendszer müködésének sematikus ábrázolása. 


\subsubsection{AzXPB kihorgonyzását követöen az SPB2 ko-lokalizációt mutat a NER komplexszel}

Az előzőekben igazoltuk, hogy az SPB2 fehérje UV sugárzás hatására ko-lokalizálódik az XPB proteinnel, ko-immunprecipitációs kísérletekben azonban nem tudtunk kimutatni interakciót a két fehérje között. Ezért következő lépésként a LacO módszer használatával megvizsgáltuk, hogy az SPB2 fehérje megjelenik-e a hibajavítási fókuszokban, ahol a nukleotid kivágó javítófolyamat pre-incíziós komplexének tagjai szerelődnek össze. Ahhoz, hogy vizsgáljuk az SPB2 megfigyelhető-e a hibajavítási fókuszokban az XPB fehérje közelében, U2OS17 sejteket transzfektáltunk GFP-LacR-XPB vektorral, majd immunfestés után kvantifikáltuk SPB2 és az XPB fúziós fehérje ko-lokalizációjának gyakoriságát. Negatív kontrollként GFP-LacR-NLS vektor transzfekciót alkalmaztunk, amely esetében szintén detektálunk GFP jelet, azonban a NER komplex tagjai nem jelennek meg a fókuszban. A kísérlet eredményét a 29. ábra szemlélteti. Eredményeink igazolták, hogy az SPB2 és az XPB ko-lokalizáció gyakorisága megnőtt, összehasonlítva GFP-LacR-NLS sejtekben tapasztalttal. Következő lépésben megvizsgáltuk, hogy az előbbiekben kimutatott funkcionális kölcsönhatásért az XPB fehérje mely régiója felelős. Ezért egy olyan vektort alkalmaztunk, melyben az XPB N-terminális doménje hiányzik (GFP-LacR-XPB $\Delta \mathrm{N}$ ), aminek eredményeként, az XPB bár képes kötődni a DNS-hez, de nem képes kölcsönhatni a DNS hibajavítás lejátszódásához szükséges fehérjékkel. Azt tapasztaltuk, hogy az XPB Cterminális doménje önmagában nem képes a hibajavítási fókuszhoz vonzani az SPB2 fehérjét. Ennek oka két módon magyarázható: (I) az XPB normál állapotában az Nterminális doménje segítségével vonzza a hibához az SPB2 fehérjét a hibajavítás folyamán, vagy (II) a javítási folyamat során az XPB más XP fehérjén keresztül toborozza a DNS-hez az SPB2-t, így, ha nem áll össze a pre-incíziós komplex a mutált XPB miatt, akkor az SPB2 fehérje sem transzportálódik a hibához. Továbbá azt tapasztaltuk, hogy habár a rendszer működéséhez nem szükséges DNS károsodás indukálása, UV kezelés hatására az SPB2XPB közös fókuszok száma megemelkedett a GFP-LacR-XPB vektorokkal transzfektált sejtek esetében, míg az üres plazmid (GFP-LacR-NLS), valamint a csonkolt XPB-t expresszáló (GFP-LacR-XPB $\Delta \mathrm{N}$ ) vektor alkalmazásával csak kevés helyen figyeltünk meg ko-lokalizációt. 


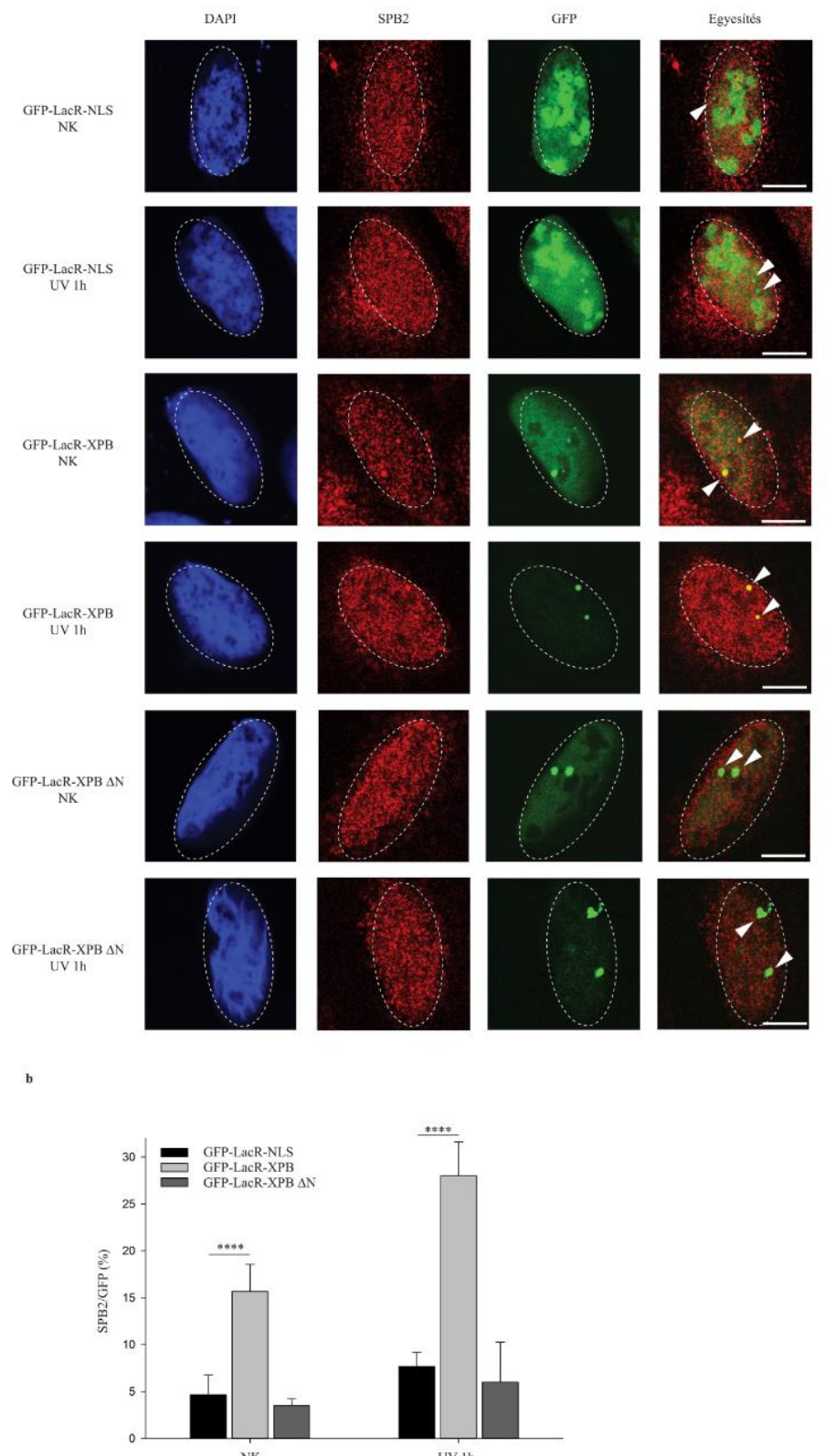

29. ábra: Az XPB és az SPB2 fehérjét tartalmazó NER pre-incíziós komplex összeszerelődésének vizsgálata:

Az SPB2 fehérje hibajavítási fókuszban való megjelenését LacO rendszer felhasználásával GFP-LacR-NLS, GFP-LacR-XPB, valamint GFP-LacR-XPB $\Delta N$ vektorral transzfektált U2OS17 sejtekben vizsgáltuk. A kísérletet kezeletlen (NK), valamint 1 órával a $12 \mathrm{~mJ} / \mathrm{cm}^{2}$ erősségü UV sugárzást követően fixált sejteken végeztük el. (a) Az immunhisztokémiai kísérletben SPB2 fehérje (piros) és a GFP-LacR fúziós fehérje (zöld) ko-lokalizációját mértük a LacO fókuszokban. A sejtmagokat DAPI (kék) fluoreszcens interkalálódó festék segítségével tettük láthatóvá. A nyilak a LacO hibajavítási fókuszokat jelzik A lépték $5 \mu \mathrm{m}$ t jelöl. (b) Az SPB2 és XPB-GFP fehérjék ko-lokalizációs gyakorisága kezeletlen (ábra bal oldala) és UV kezelt sejtekben (ábra jobb oldala). 
Mindezen eredmények alátámasztják azon korábbi feltételezésünket, hogy UV sugárzás hatására az SPB2 a nukleotid kivágó hibajavítási fókuszokba transzportálódik, ahol az XPB faktorral ugyan fizikai kapcsolatba nem lép, de funkcionális együttmüködés tapasztalható közöttük.

\subsubsection{Az SPB2 és az RNS Polimeráz II komplex kölcsönhatásának vizsgálata.}

Korábbi kísérleteinkkel igazoltuk, hogy az SPB2 az XPB fehérjével együttmüködve szerepet játszik a NER hibajavító útvonal középső szakaszában. Továbbá eredményeinkből az is kiderült, hogy a GG-NER hibafelismerő folyamatában az SPB2 nem játszik szerepet, valamint szintén nem találtunk bizonyítékot arra, hogy kapcsolat állna fent az SPB2 és az XPF fehérje között. Azonban az nem zárható ki, hogy az SPB2 protein rendelkezik más funkcióval is a NER útvonal további szakaszaiban. Ilyen folyamat lehet például a TC-NER hibafelismerési szakasza, illetve a Pol II elmozdítása a hibás DNS szakaszról (backtracking). Annak eldöntésére, hogy ezen lépésekben szükséges-e az SPB2, vizsgáltuk, hogy kölcsönhat-e olyan fehérjével, mely mindkét hibajavító szakaszban szerepet játszhat. Ennek igazolására ko-immunprecipitációs kísérletet végeztünk GFP-SPB2 fúziós fehérjét expresszáló vektorral transzfektált U2OS sejteken. A transzfekciót követően a sejteket UV sugárzásnak tettük ki, majd 2 és 4 óra inkubációs időt követően vizsgáltuk az SPB2 és az elongáló Pol II (S2P RPB1) kölcsönhatását. Az immunprecipitációt anti-GFP ellenanyagal végeztük, majd az ezt követő Western blot során anti-S2P RPB1 ellenanyagot alkalmaztunk a fennálló kölcsönhatás kimutatására. Az immunprecipitáció sikerességét anti-GFP ellenanyaggal teszteltük (30. a ábra). Azonban nem tudtunk az SPB2 és az S2P RPB1 között interakciót kimutatni. A Western blot kontrolljaként az immunprecipitációs eljárás alkalmával használt transzfektált U2OS sejtek lizátumából származó, ún. input minták szolgáltak, melyek kemilumineszcens jele a 30. b ábrán látható. 


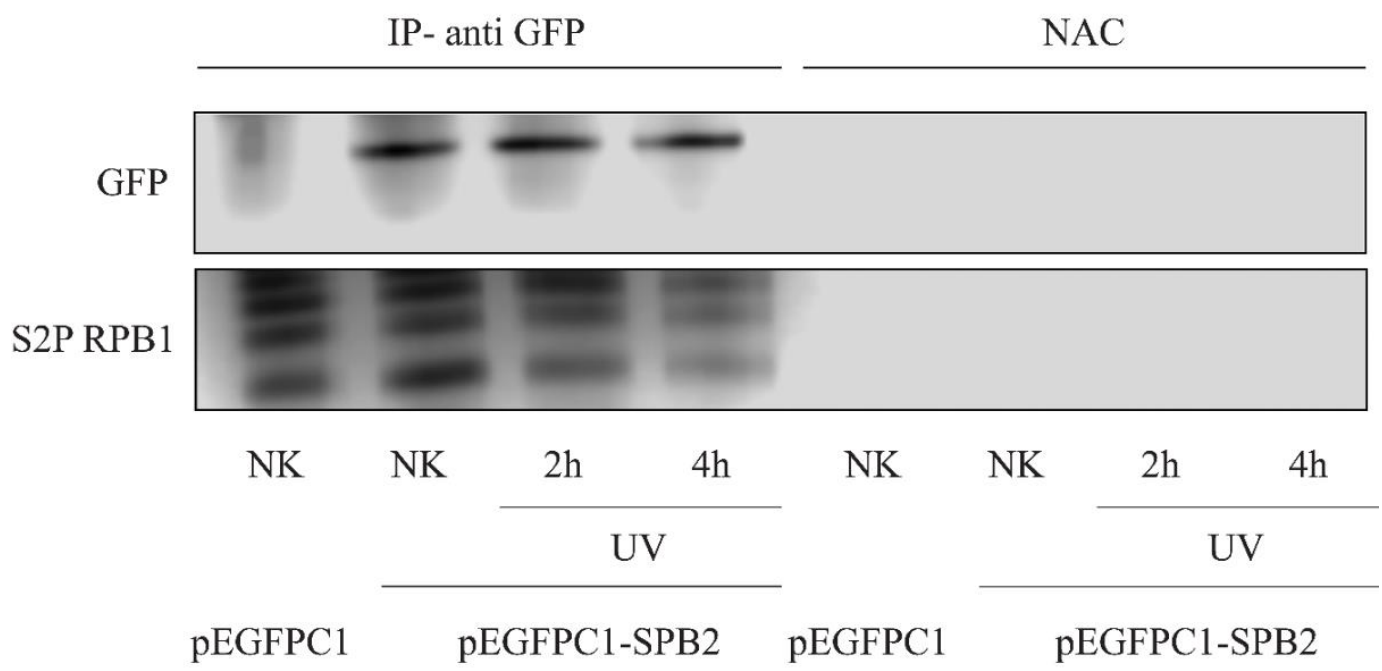

b

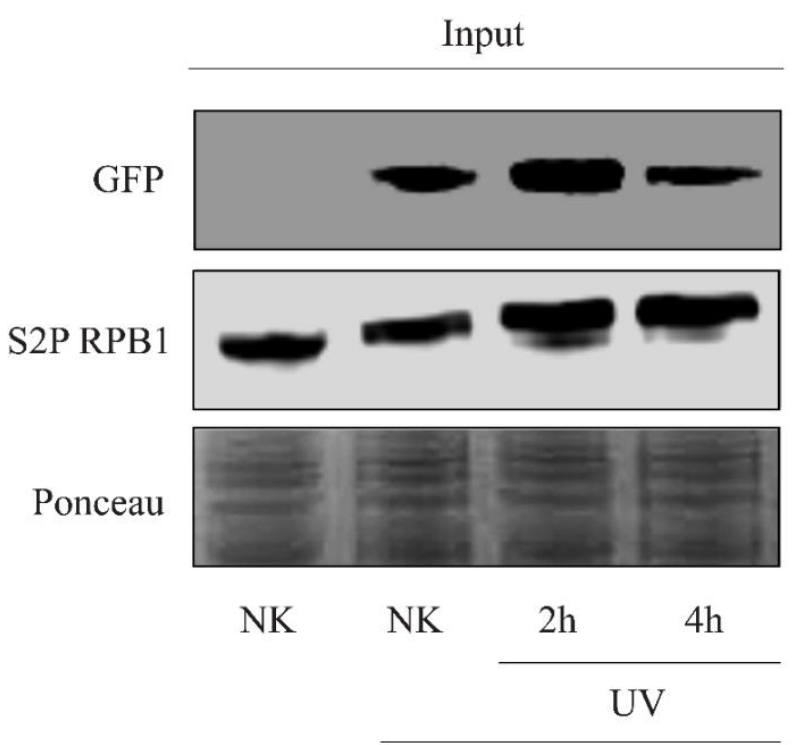

pEGFPC1 pEGFPC1-SPB2

30. ábra: Az SPB2 és az S2P RPB1 fehérje közti kölcsönhatás vizsgálata U2OS sejtekben:

(a) Kezeletlen, valamint 2 és 4 óra inkubációs idővel a $16 \mathrm{~mJ} / \mathrm{cm}^{2}$ erősségü UV sugárzást követően összegyüjtött SPB2-GFP transzfektált U2OS sejtekben az SPB2 és az S2P RPB1 fehérje interakcióját vizsgáltuk ko-immunprecipitációval. Az immunprecipitációt anti-GFP antitesttel végeztük. A NAC a kísérlet negatív kontrollja (b) A ko-immunprecipitációs kísérlet input kontrollja. Az „Input” minták esetében teljes sejtlizátumból származó mintákon vizsgáltuk az SPB2-GFP fúziós fehérje (GFP) és az S2P RPB1 protein szintjét. Az egyenletes mintafelvitelt Ponceau festéssel igazoltuk. 


\subsubsection{Az UV sugárzás hatására kialakuló ubiquitilált környezetben kimutatható az SPB2}

\section{fehérje jelenléte}

Korábbi eredményekből már ismert, hogy az ubiquitin szignalizációs folyamatok számos DNS hibajavító útvonal finom szabályzásában szerepet játszanak. Ilyen az UV indukálta NER útvonal is, amely során a DNS hibajavításban részt vevő fehérjék ubiquitilálódnak ${ }^{43}$. Irodalmi adatokból tudjuk, hogy az ubiquitin PTM már a hiba felismerés során szerepet kap, ugyanis az XPC fehérje DNS-hez kötődésének erősségét a DDB-Cul4 általi ubiquitin módosítása szabályozza ${ }^{187,188}$. A szakirodalomból azt is ismerjük, hogy az SPB2 ubiquitilált fehérjékhez tud kapcsolódni, azonban önmaga nem ubiquitilálódik ${ }^{182}$. Korábbi eredményeinkben igazoltuk, hogy UV kezelés hatására az SPB2 a NER hibajavítási fókuszokba transzportálódik, ahol az XPB fehérjével azonos genomi lókuszokban jelenik meg. Ezen eredmények felvetették annak lehetőségét, hogy az SPB2 asszociációja a NER komplexszel ubiquitiláció által szabályozott lehet. Annak vizsgálatára, hogy az ubiquitiláció befolyásolja-e az SPB2 DNS hibánál való megjelenését, ko-immunprecipitációs (co-IP) technikát alkalmaztunk. Az SPB2 és az ubiquitin közötti interakció kimutatására U2OS sejteket transzfektáltunk SPB2-GFP, valamint hemagglutinin-ubiquitin (HA-Ub) fúziós fehérjéket expresszáló plazmidokkal. A kezeletlen, valamint 2 és 4 óra inkubációs idővel az UV kezelést követően összegyüjtött transzfektált U2OS sejteken co-IP-t hajtottunk végre anti-hemagglutinin ellenanyaggal, majd Western blot során anti-GFP antitesttel mutattuk ki az SPB2 és az ubiquitin molekulák között esetlegesen fennálló kölcsönhatást. Az immunprecipitáció sikerességét anti-HA ellenanyagokkal teszteltük (31. a ábra). A Western blot kontrolljaként az immunprecipitációs eljárás alkalmával használt transzfektált U2OS sejtek lizátumából származó, ún. input minták szolgáltak, melyek képe a 31. b ábrán látható. Az UV sugárzással nem kezelt minták esetében nem tapasztaltunk interakciót az SPB2 és az ubiquitilált fehérje pool között, azonban sikerült kapcsolatot kimutatnunk az SPB2 és az Ub között mind 2, mind 4 órával UV kezelést követően.

Mindezen eredményekből arra következtethetünk, hogy az SPB2 fehérjének szerepe lehet a NER útvonal ubiquitiláció általi finomszabályozásában. Azonban az sem zárható ki, hogy az ubiquitin, mint poszttranszlációs módosítás befolyásolja az SPB2 NER útvonalban való részvételét. 
a

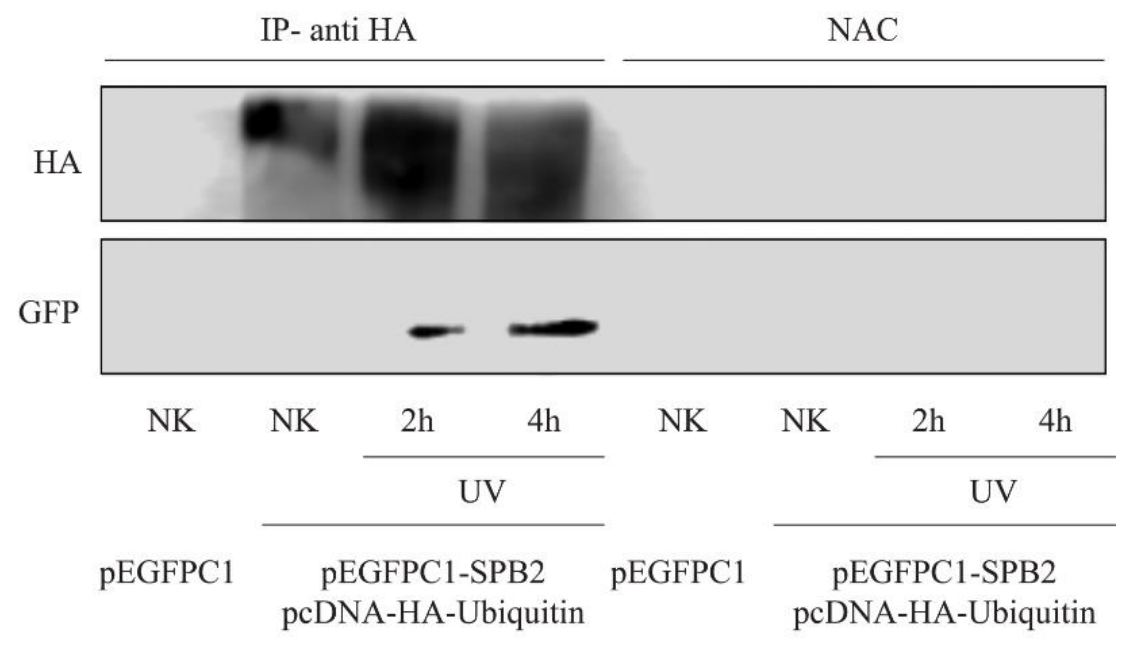

b

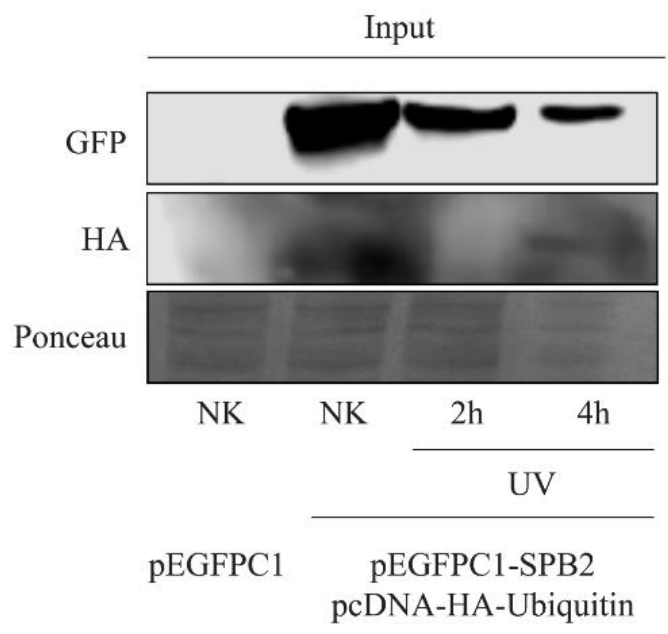

31. ábra: Az SPB2 fehérje és az ubiquitin molekulák közti kölcsönhatás vizsgálata
U2OS sejtekben:
(a) Kezeletlen, valamint 2 és 4 óra inkubációs idővel a $16 \mathrm{~mJ} / \mathrm{cm}^{2}$ erősségü UV sugárzást
követően összegyüjtött SPB2-GFP, HA-ubiquitin ko-transzfektált U2OS sejtekben ko-
immunprecipitációs eljárással vizsgáltuk az SPB2 és ubiquitin interakcióját. Az
immunprecipitációt anti-HA antitesttel végeztük. A NAC a kísérlet negatív kontrollja (b)
A ko-immunprecipitációs kísérlet input kontrollja. Az „Input” minták esetében teljes
sejtlizátumban vizsgáltuk az SPB2-GFP fúziós fehérje (GFP) és ubiquitin (HA) szintjét. Az
egyenletes mintafelvitelt Ponceau festéssel igazoltuk.

Továbbá az irodalmi adatokkal ellentétben az sem zárható ki, hogy a vizsgált sejtvonalban maga az SPB2 fehérje ubiquitilálódik UV sugárzás hatására, mely funkciójának 
módosításához vezet. Ezen hipotézisek igazolására további kísérleteket tervezünk elvégezni a közeljövőben.

\subsubsection{Az SPB2 fehérje lokalizációja eltérö kontroll és BCC (bazális sejtes karcinóma) tumoros szövetminták között}

A közelmúltban számos olyan tanulmány látott napvilágot, melyben a tumorképződést, valamint a metasztázis előrehaladását elősegítő vagy gátló fehérjéket azonosítottak, azonban ezen fatorok hatása eltérő a különböző tumorok esetében. Az irodalomban találunk példát az SPB2 emelkedett expressziójának a húgyhólyag tumorral vagy nyelöcső laphámrákkal diagnosztizált betegek túlélési arányára gyakorolt negatív hatásáról is ${ }^{189,190}$. Ezekkel pont ellentétes folyamatot írtak le emlö-, ill. hasnyálmirigy tumorok esetében, ahol a csökkent SPB2 expresszió hozható összefüggésbe az alacsony túlélési eséllyel ${ }^{191-194}$. A dolgozatom korábbi részében bemutattam, hogy az SPB2 relatív mRNS szintje szignifikánsan megnő UV sugárzás hatására mind keratinocita, mind malonoma sejtekben (13. és 14. ábra). Továbbá kapcsolatot találtunk UV sugárzás hatására az SPB2 és a NER útvonalban részt vevő XPB között (25., 26. és 29. ábra). Az irodalomból ismert, hogy a NER útvonal bármely tagjának mutációja súlyos bőrtumorok kialakulásához vezethet, melyek esetében a páciensek alacsony túlélési esélyeivel számolhatunk ${ }^{195,196}$. Az SPB2 szerepének, valamint

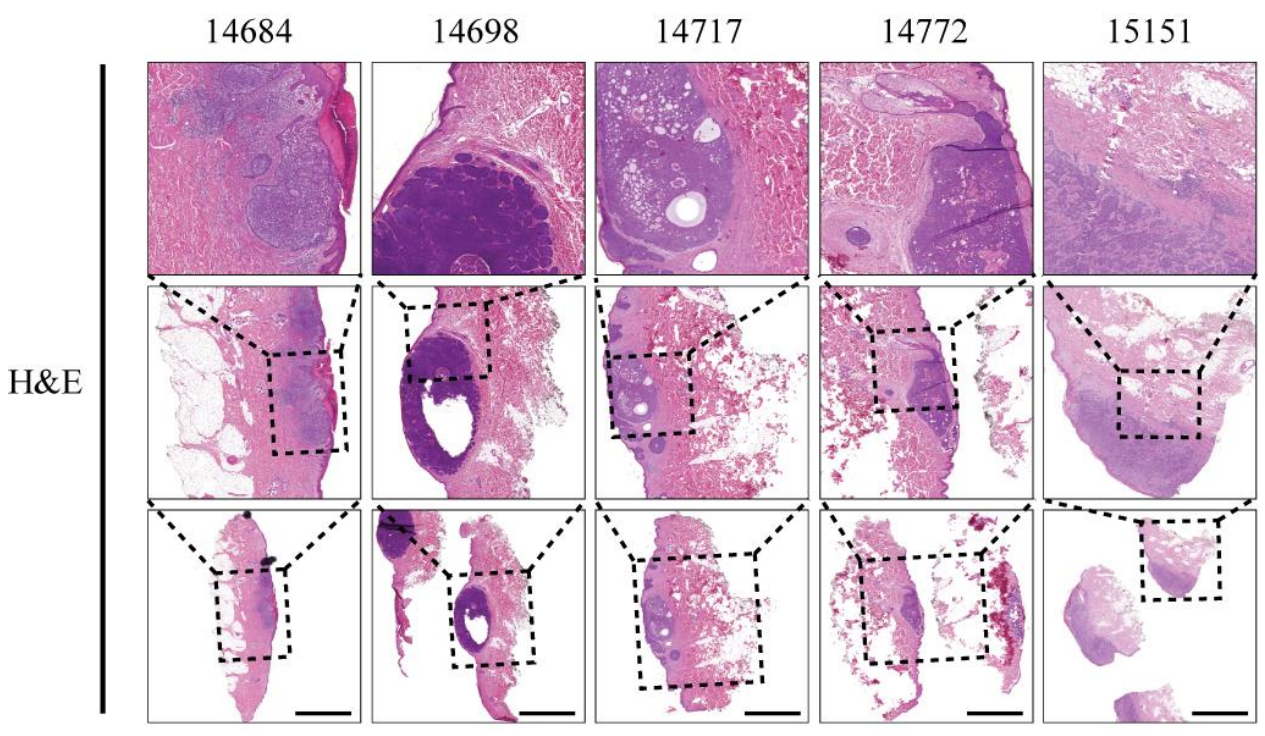

32. ábra: Bazális sejtes karcinóma (BCC) tumoros szövetmetszetek hematoxilin-eozin festése:

Páciensekből származó BCC tumorok hematoxilin-eozin festésével különítettük el a metszetek tumoros és ép részeit. A számok a betegek kódszámait jelzik. A lépték $4000 \mu \mathrm{m}$ t jelöl. 
előfordulásának vizsgálatára bőrsejt eredetü bazális sejtes karcinóma (BCC) tumorokból származó szövetmintákon, immunhisztokémiai eljárást végeztünk, melyet a 32. ábra szemléltet.

A várt eredményekkel ellentétben nem tapasztaltunk különbséget az SPB2 fehérje mennyiségében a normál és tumoros szövetrészek között, azonban megfigyeltük, hogy az SPB2 sejten belüli lokalizációja különbözik a vizsgált szövettípusok között. Ép szövetrészekben az SPB2 a sejtmagban és a citoplazmában is megfigyelhető, míg a tumoros részeken az SPB2 kizárólag a citoplazmában helyezkedik el. A sejtmagban egyáltalán nem, vagy csak nagyon kis mennyiségben láttunk SPB2 fehérjét, mely eredményünket a képek analízisével is megerősítettük. Ezen eredményeket a 33. ábra szemlélteti. Az SPB2 szubcelluláris lokalizációjának eloszlásáról a normál és tumoros szövetekben reprezentatív hisztogramokat készítettünk, melyek a 33. b és d ábrán láthatók. Mindezen eredményekből arra a következtetésre jutottunk, hogy az SPB2 egy potenciálisan új szabályozó faktor az UV sugárzás indukálta javító mechanizmusban. Feltételezéseink szerint a tumoros sejtekben az SPB2 sejtmagba történő transzportja hibát szenved, ezáltal a fehérje nem képes ellátni a feladatát a hibajavítási fókuszokban, emiatt a DNS javító mechanizmus hibát szenved, mely akár a mutációs ráta emelkedéséhez is vezethet. 


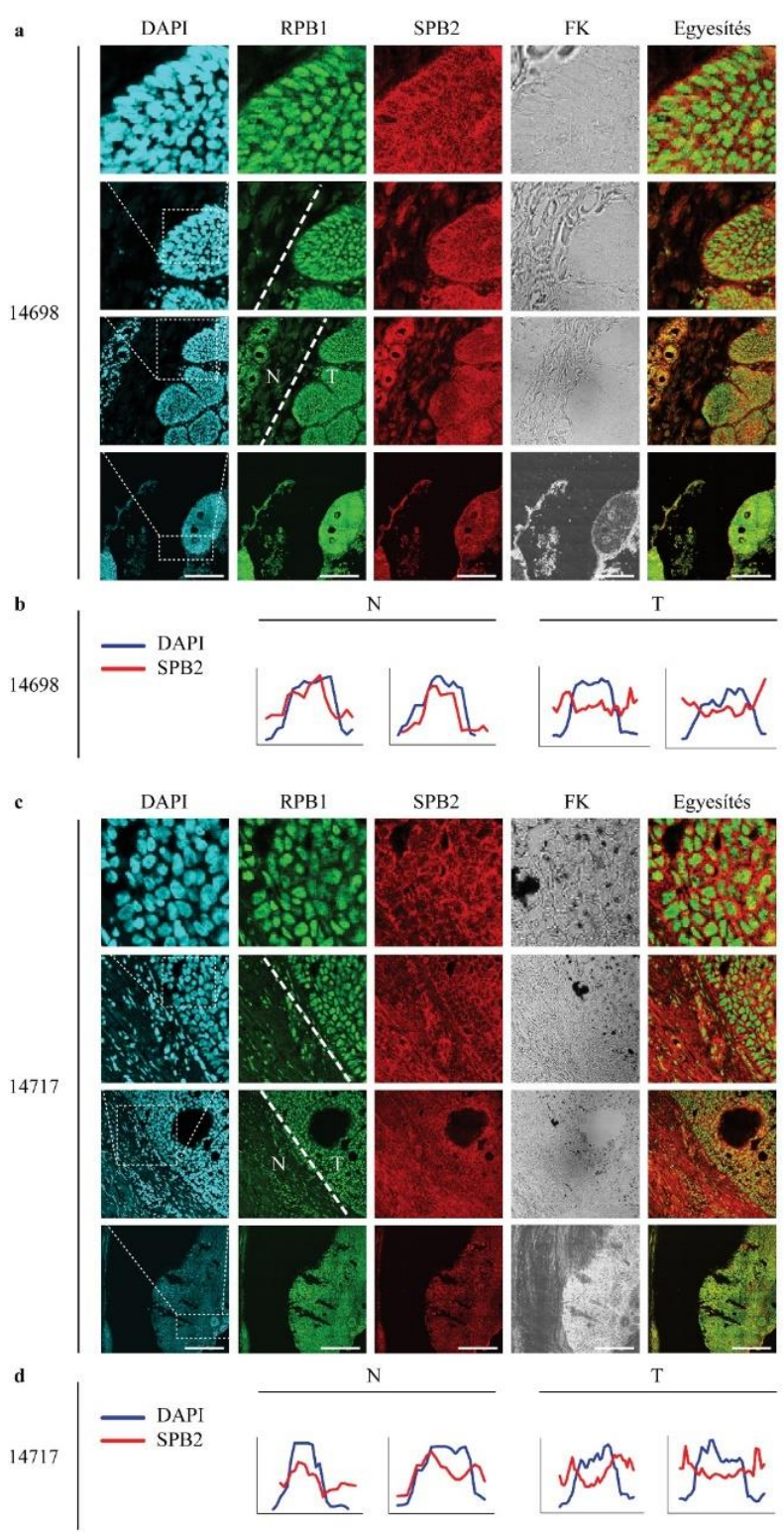

33. ábra: Az SPB2 fehérje mennyisége és lokalizációja bazális sejtes karcinóma mintákban:

(a és c) Daganatos betegekből származó BCC metszetekben az SPB2 (piros) és RPB1 (zöld, anti-Pol II) fehérjék mennyiségét és ko-lokalizációját vizsgáltuk immunhisztokémiai eljárás segítségével. DAPI (kék) fluoreszcens interkalálódó festék segítségével tettük láthatóvá a sejtmagokat. A szövetek ép, $(\mathrm{N})$ és tumoros $(\mathrm{T})$ részeit jelöltük. Az FK a fáziskontraszt képeket jelöli. A lépték $180 \mu \mathrm{m}$-t jelöl. (b és d) Az alkalmazott ellenanyagok fluoreszcencia intenzitásának meghatározásával, valamint az adatokból generált grafikonok egymásra vetítésével az SPB2 (piros) és DAPI (kék) ko-lokalizációját vizsgáltuk Fiji (Image J) szoftverrel, mellyel az SPB2 szubcelluláris lokalizációját szemléltettük normál (bal oldali) és tumoros (jobb oldali) szövetrészekben. 


\subsection{SPB10 UV sugárzás hatására kialakuló sejtválaszban betöltött szerepe}

A továbbiakban az SPB10 fehérjéhez kapcsolódó vizsgálati eredményeinket mutatom be, melyek egy jelenleg is folyó, mindeddig befejezetlen kutatási téma részei.

\subsubsection{UV kezelés hatására az SPB10 relatív mRNS szintje megemelkedik a vizsgált sejtvonalakban}

A dolgozatom első felében ismertetett microarray kísérletben UV kezelés hatására az SerpinB10 gén is igen erös, 18,08-szoros expresszió növekedést mutatott, melyből arra következtettünk, hogy szerepe lehet az UV sugárzás hatására kialakult sejtválaszban Hker E6SFM sejtekben (10. ábra). Az eredmények ellenőrzését ebben az esetben is qPCR módszerrel végeztük, amihez az SPB10 relatív expresszió szintjének változását kezeletlen, valamint UV sugárzást követően 2, 8 és 24 órával összegyüjtött Hker E6SFM sejtekben vizsgáltuk. Az eredmények a 34. ábrán láthatók. Azt tapasztaltuk, hogy a microarray eredményekhez hasonlóan, az SPB10 mRNS szintje emelkedett Hker E6SFM sejtekben, mivel 2 órával az UV sugárzást követően 7,3-szoros, 8 óra elteltével 54,7-szeres mRNS szint növekedést figyeltünk meg. A 24 órás mintáknál, ahogy az SPB2 esetében is, mRNS szintbeli csökkenést mutattunk ki a 2 és 8 órás mintákhoz képest, de még mindig 12,2-szer több mRNS mennyiséget mértünk a kontrollhoz képest.

Annak eldöntésére, hogy ezen jelenség csak Hker E6SFM sejtvonalban, vagy más keratinocita sejtekben (HaCaT), illetve egyéb bőrben elöforduló, melanoma (A375) sejtben is megfigyelhető-e, az SPB10 relatív expresszióját vizsgáltuk qPCR-ral kezeletlen, valamint 2, 8 és 24 óra inkubációs idővel az UV kezelést követően összegyüjtött sejtekben. Eredményeinket a 34. ábra szemlélteti.

A Hker E6SFM sejtvonalban tapasztalt eredményhez hasonlóan, UV sugárzás hatására mindkét sejtvonalnál hasonló mintázatot figyeltünk meg a relatív mRNS értékeket ábrázolva. A kapott mRNS szintek értékeinek százalékos változásai különböztek egymástól, HaCaT sejtvonal esetében 5,2, 27,3 és 4,4-szeres emelkedést, míg A375 sejtek vizsgálatakor 0,5, 4,5 és 1,4-szeres mRNS szintbeli növekedést mutattunk ki az UV kezelt mintákban a kezeletlen sejtekhez viszonyítva. Ezen különbség magyarázható a sejtvonalak eltérő eredetével, de elmondhatjuk, hogy a vizsgált sejtvonalak mindegyikében megfigyeltük az SPB10 relatív expressziójának emelkedését UV sugárzás hatására. 


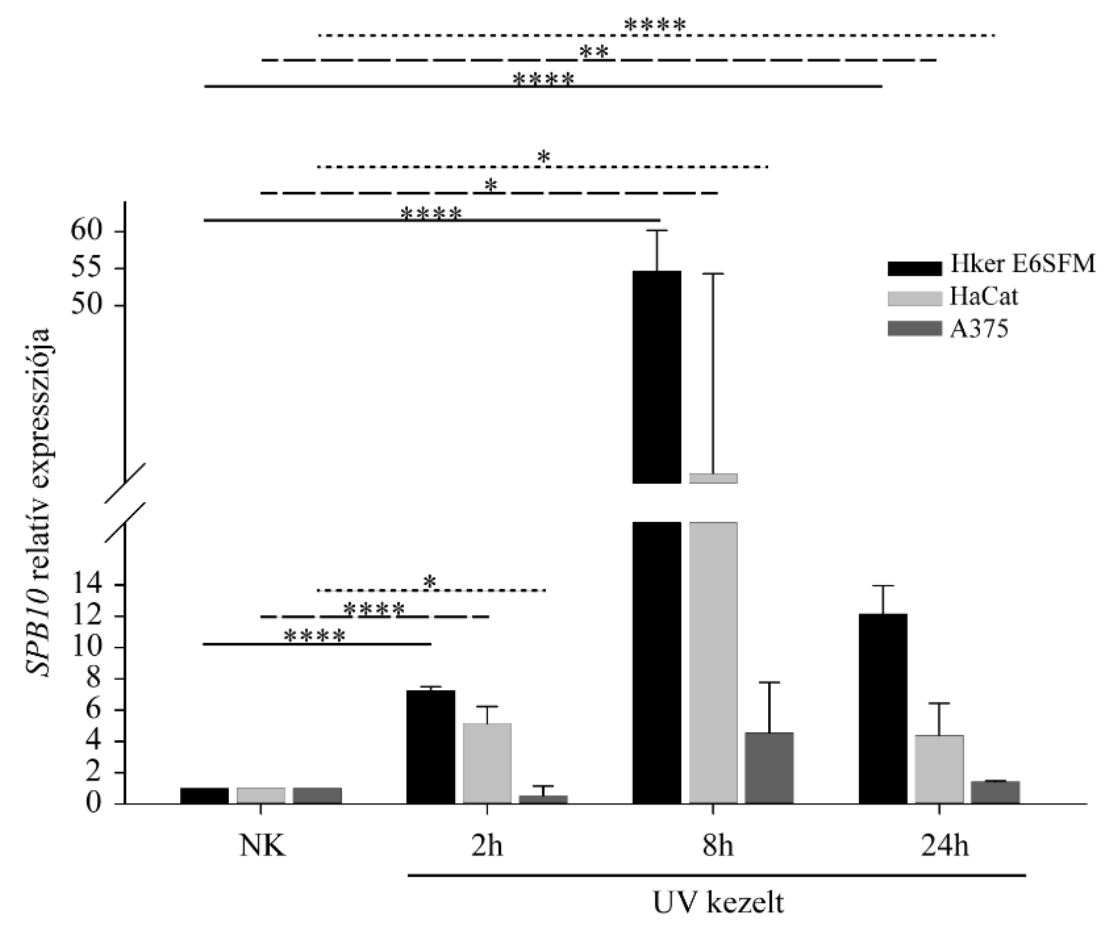

34. ábra: Hker E6SFM, HaCaT és A375 sejteken mért UV hatására bekövetkező SPB10 génexpresszió változás mértéke:

A Hker E6SFM, HaCaT és A375 sejteket $80 \mathrm{~mJ} / \mathrm{cm}^{2}$ erősségü UV sugárzással kezeltük, majd 2, 8 és 24 óra inkubációs időt követően qPCR módszerrel meghatároztuk az SPB10 relatív mRNS szintjét

\subsubsection{Az SPB10 fehérje csendesítése nem befolyásolja a sejtek túlélését}

Irodalmi adatokból ismert, hogy normál körülmények között az SPB10 a mieloid leukémia sejtek proliferációját segíti elő, míg a növekedési faktorok hiányában a sejtek apoptózisát indukálja ${ }^{172}$. Előzetes eredményeink arra utalnak, hogy az SPB10-nek szerepe lehet az UV kiváltotta sejtválaszban. Ezen eredményekből kiindulva, kíváncsiak voltunk, hogy az SPB10 befolyásolja-e a sejtek túlélését UV sugárzás hatására. Ezért U2OS sejtekben siRNS segítségével csendesítettük az SPB10-et, majd UV sugárzás hatására 2, 4, 6 és 24 óra inkubációs idő elteltével tripánkék festék segítségével meghatároztuk az élő sejtek arányát. A kísérletek összesített eredményét a 35. ábra szemlélteti. 


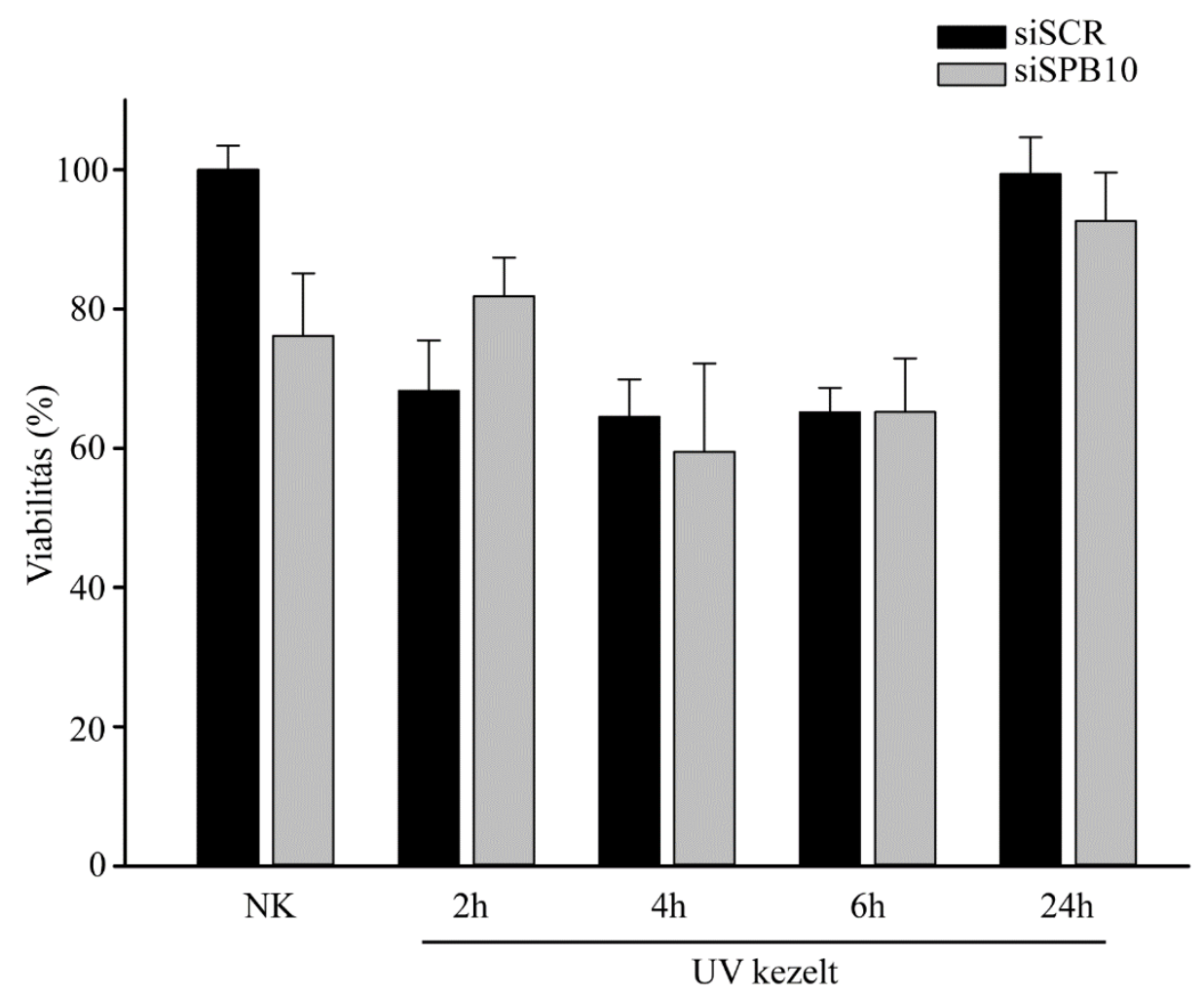

\section{5. ábra: SPB10 csendesített sejtek UV kezelés utáni túlélésének aránya:}

A U2OS sejteket $16 \mathrm{~mJ} / \mathrm{cm}^{2}$ erősségü UV sugárzással kezeltük, majd tripánkék festék segítségével vizsgáltuk a sejtek túlélését 2, 4, 6 és 24 órát követően. A kísérletet SPB10 csendesített (siSPB10), valamint nem csendesített (siSCR) sejteken is elvégeztük.

A korábbi irodalmi adatoknak megfelelően az UV sugárzás hatására a sejtek életképessége csökkent, majd az inkubációs idő növelésével a túlélö sejtek mennyisége emelkedett. Azonban a kontroll sejtekben (siSCR) tapasztalt túlélési értékekhez képest nem tapasztaltunk szignifikáns különbséget siSPB10 sejtekben, amely alapján arra következtettünk, hogy az SPB10 nem befolyásolja a sejtek UV kezelést követő túlélési arányát.

\subsubsection{Az SPB10 fehérje csendesítése befolyásolja a DNS hibajavítás gyorsaságát}

Előzetes eredményeink arra utalnak, hogy a Serpin fehérjecsalád két tagja, az SPB2 és az SPB10 is szerepet játszik az UV kiváltotta sejtválaszban. Ezért megvizsgáltuk, hogy az SPB10 befolyásolja-e az UV okozta DNS hibák javítását. U2OS sejtekben az SPB10 
géntermék siRNS csendesítését végeztük, majd az SPB10 hiányos sejteket UV kezelésnek vetettük alá. A kezeletlen sejteken, valamint 0,6 és 24 órával az UV kezelést követően a sejteken Comet-esszé kísérletet végeztünk, ahol az S-fázisú sejtekben vizsgáltuk az UV okozta DNS károsodás hatására kialakult egyes-szálú DNS szakaszok jelenlétét. A DNS károsodás mértékét a Comet kísérletben az üstökös „fejének” (sejtmagi) és „farkának” vagy csóvájának (károsodott DNS) fluoreszcencia intenzitásbeli különbségéből számoltuk ki.

A 36. ábrán bemutatott eredményeink alapján megállapítható, hogy S-fázisú sejtekben a sérült DNS mennyisége UV sugárzás hatására 6 és 24 órával a kezelést követően megemelkedik. Azonban SPB10 csendesítés hatására U2OS sejtekben bár megjelenik az úgynevezett „csóva” UV kezelést követően, viszont a DNS hibák sokkal gyorsabban kijavítódnak, így már 6 óránál is szignifikánsan kisebb DNS csóvát tapasztalunk, a kontroll sejtekben tapasztalthoz képest. Az UV kezelés után 24 órával vizsgált sejteknél a károsodott DNS mennyisége siSPB10 kezelt mintáknál a kontrollhoz hasonlóan csökken. Mindezen eredményekből azt a konklúziót vontuk le, hogy az SPB10-nek szerepe van az UV sugárzás következtében kialakult DNS hibák javításának folyamatában, valószínűsíthetően az SPB10 a DNS hibajavítást lassítja, így segíti elő a precízebb, hibáktól mentes javítás folyamatát. 
a
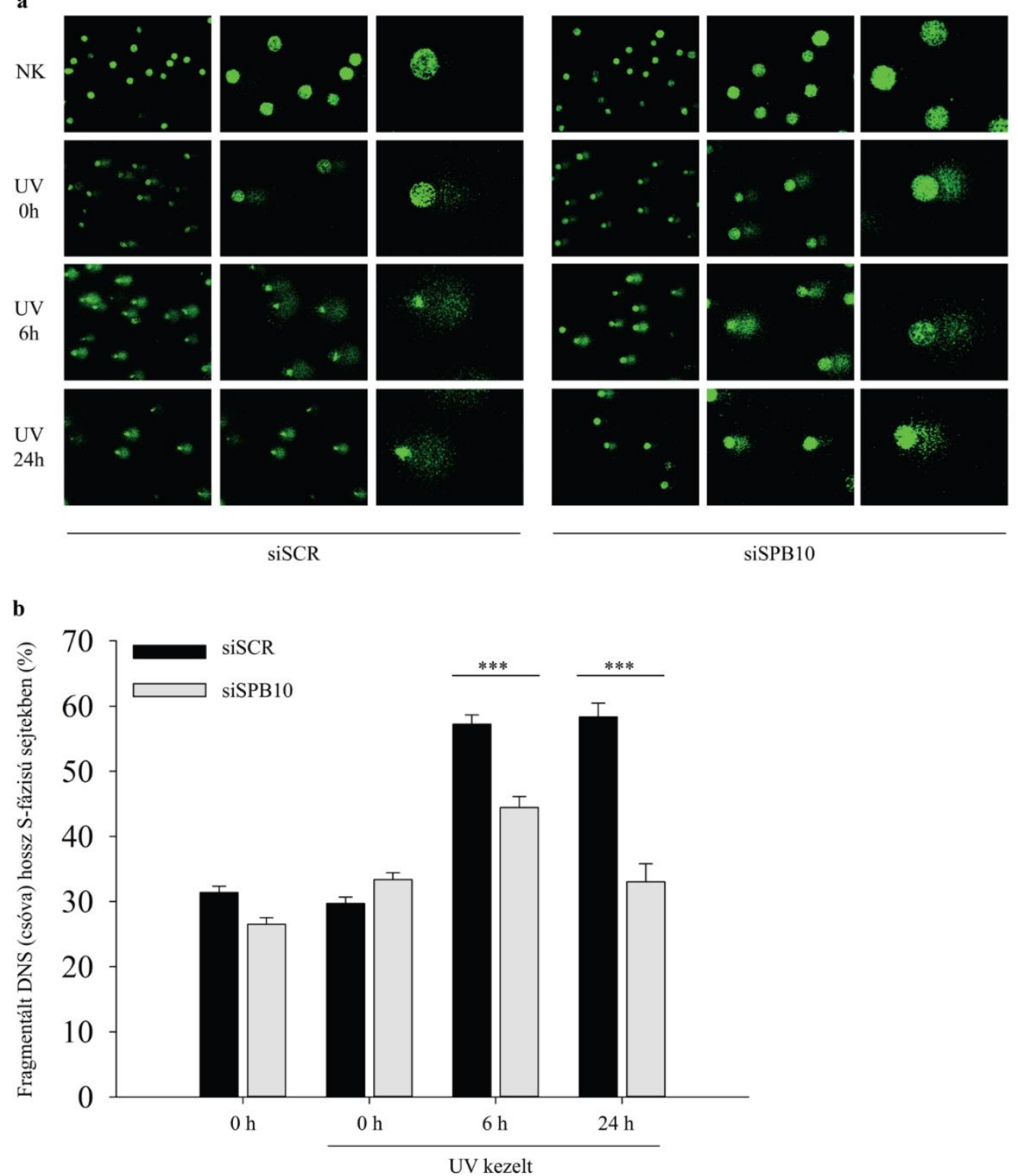

36. ábra: Az SPB10 hatásának vizsgálata az UV sugárzás okozta DNS hibák javítására S-fázisú U2OS sejtekben:

Kezeletlen, valamint 0 , 6 és 24 óra inkubációs idővel a $20 \mathrm{~mJ} / \mathrm{cm}^{2}$ erôsségü UV sugárzást követően összegyüjtött S-fázisú U2OS sejtekben vizsgáltuk a károsodott DNS mennyiségét Comet-esszé segítségével. A kísérletet SPB10 csendesített (siSPB10), valamint kontroll (siSCR) sejtpopuláción is elvégeztük. (a) Reprezentatív ábra, mely az siSPB10 (jobb oldali) és siSCR RNS-sel (bal oldali) transzfektált, valamint bromodeoxyuridine (BrdU) festékkel jelölt S-fázisú U2OS sejtekben mutatja az egyes-szálú DNS szakaszok jelenlétét. (b) A kísérlet során azonosított egyes-szálú DNS szakaszok százalékos arányának kvantitatív kiértékelése látható a grafikonon. 


\subsubsection{Az SPB10 kölcsönhat a H3 fehérjével}

Az előzőekben bemutatott eredményeink arra mutattak, hogy az SPB10 - hasonlóan az SPB2 fehérjéhez - szerepet játszik az UV okozta DNS hibajavításban, bár a két fehérje az UV sugárzás hatására kialakult hibák kijavításában más folyamatokat szabályozhat. Annak tisztázására, hogy az SPB10 és a kromatin szerkezet építőköveinek számító hiszton fehérjék között alakul-e ki kapcsolat UV kezelés hatására ko-immunprecipitációs eljárást alkalmaztunk. Az SPB10 és a H3 közti interakció kimutatására U2OS sejteket transzfektáltunk SPB10-GFP fúziós fehérjét expresszáló plazmiddal, majd a kezeletlen és UV kezelt sejteken immunprecipitációt végeztünk anti-GFP ellenanyaggal. Végül Western blot technika segítségével, anti-H3 ellenanyagot alkalmazva, teszteltük a kölcsönhatást a két fehérje között. Kísérletünkből kiderül, hogy az SPB10 kölcsönhat a H3 fehérjével, valamint UV kezelés hatására ez a kapcsolat erősödik a két fehérje között. A kísérleti eredményeket a 37. a ábra szemlélteti. A Western blot kontrolljaként az immunprecipitációs eljárás alkalmával használt transzfektált U2OS sejtek lizátumából származó, ún. input minták szolgáltak, melyek képe a 37. c ábrán látható.

A ko-immunprecipitációs kísérletek megerősítésére anti-H3 antitesttel is elvégeztük az immunprecipitációt, majd Western blot kísérletben anti-GFP ellenanyaggal vizsgáltuk a kölcsönhatást kontroll körülmények között, illetve 2 és 4 órával az UV kezelést követően (37. b ábra). Az immunprecipitációhoz használt U2OS teljes sejtlizátumból származó input minták a 37. d ábrán láthatók. A kísérlet megerősíti korábbi eredményeinket, mely szerint az SPB10 fizikai kapcsolatba lép a H3 fehérjével normál körülmények között, és UV sugárzás hatására a kölcsönhatásuk erősödik. Eredményeink alátámasztják hipotézisünket, mely szerint az SPB10 fehérje részt vesz az UV sugárzás hatására képződött DNS hibák javításának folyamatában. 
a

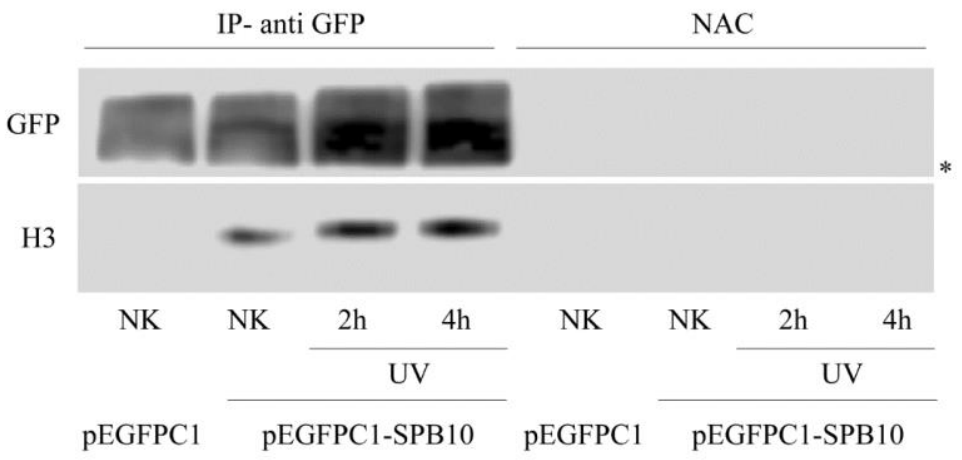

b

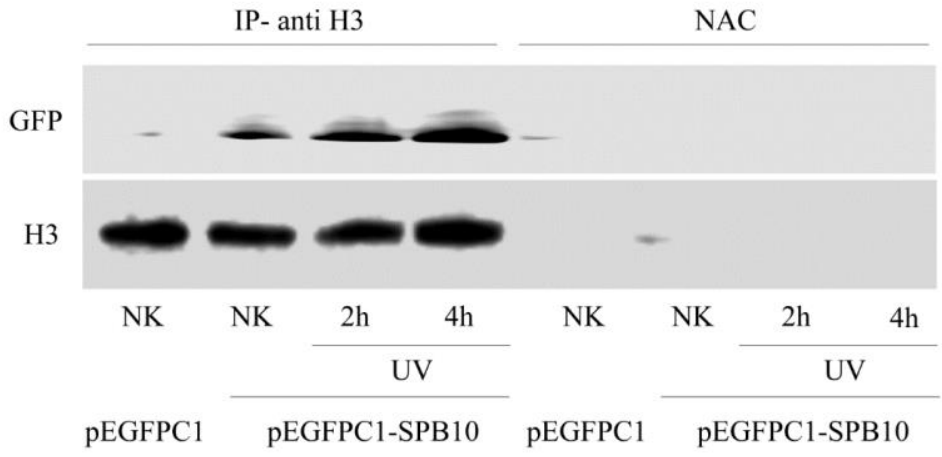

c

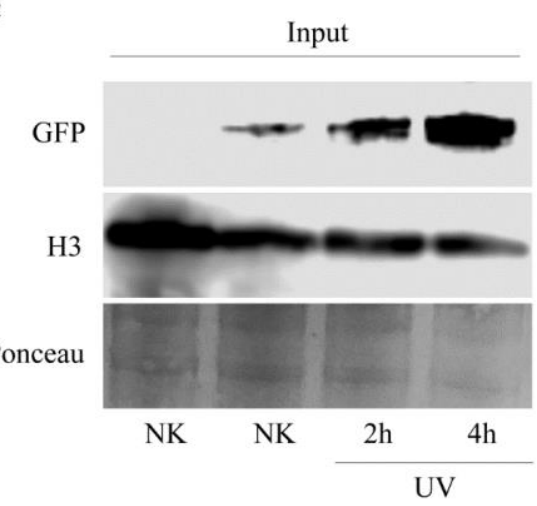

d

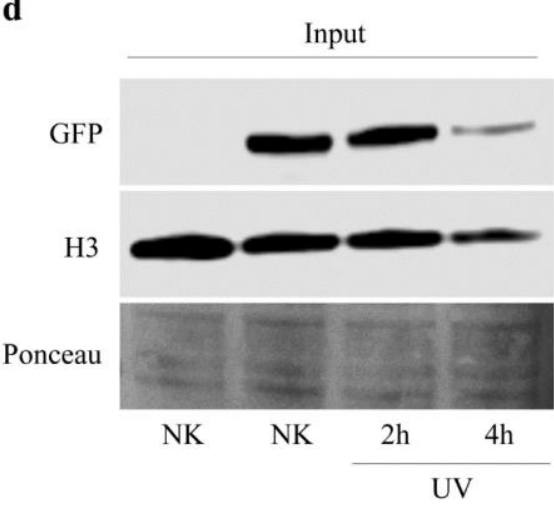

pEGFPC1 pEGFPC1-SPB10

pEGFPC1 pEGFPC1-SPB10

\begin{abstract}
37. ábra: Az SPB10 és a H3 fehérje közti kölcsönhatás vizsgálata UV kezelés hatására U2OS sejtekben:

(a) Kezeletlen, valamint 2 és 4 óra inkubációs idővel a $16 \mathrm{~mJ} / \mathrm{cm}^{2}$ erősségű UV sugárzást követően összegyüjtött SPB2-GFP transzfektált U2OS sejtekben az SPB2 és a H3 fehérje interakcióját vizsgáltuk ko-immunprecipitációs eljárással. Az immunprecipitációt antiGFP antitesttel végeztük. A NAC a kísérlet negatív kontrollja (b) Az „a” ábrán látható eredmények alátámasztása anti-H3 antitesttel végzett immunprecipitációval. (c) Az „a” ábrán, (d) a „b” ábrán látható ko-immunprecipitációs kísérlet input kontrollja. Az „Input” minták esetében teljes sejtlizátumban vizsgáltuk az SPB2-GFP fúziós fehérje (GFP) és a H3 protein szintjét. Az egyenletes mintafelvitelt Ponceau festéssel igazoltuk.
\end{abstract}




\section{Eredmények megvitatása}

A szervezetünket folyamatos külső és belső forrásból származó DNS károsító hatások érik. Ezek közül az egyik legismertebb az UV sugárzás, amelyből az ózonpajzs vastagságának csökkenése miatt növekvő mennyiség kerül a Föld légkörébe. Az UV által kiváltott DNS károsodások, illetve ezekre adott sejtválasz igen fontos kutatási terület, hiszen a nem, vagy lassan kijavított hibák gyakran tumorképződéshez vezetnek.

Kutatócsoportunk egy korábban létrehozott Hker E6SFM sejtvonalat felhasználva vizsgálta az UV sugárzás hatására kialakuló génexpresszió változásokat ${ }^{177,197,198}$. Tanulmányunkban kezeletlen, valamint UV sugárzással kezelt Hker E6SFM sejtek mRNS profilját hasonlítottuk össze microarray kísérletben. Eredményeinkben 244 génben mutattunk ki szignifikáns változást UV sugárzást követően, melyből 21 gén mRNS szintjében tapasztaltunk emelkedést a kezelés hatására. Az UV kezelést követően emelkedett transzkripciós aktivitású gének között megjelent egy fehérjecsalád - Serpinek - néhány tagja, nevezetesen a SerpinB2, SerpinB10, valamint a SerpinB13. A SerpinB család fehérjéivel az irodalomban számos funkciót feljegyeztek, többek között ezen család tagjait leírták már az immunválaszban, gyulladásos folyamatokban, nyáltermelésben, apoptózisban, a tumor metasztázis szabályozásában, valamint az autoimmunitás folyamatában is, azonban szerepüket az UV kiváltotta sejtválaszban még nem vizsgálták ${ }^{133,134}$. Eredményeink azonban azt sugallták, hogy a SerpinB fehérjecsalád több tagjának is szerepe lehet az UV kiváltotta sejtválaszban Hker E6SFM sejtvonalban. Ezért dolgozatomban a két legnagyobb változást mutató gén, a SerpinB2 (SPB2) és SerpinB10 (SPB10) vizsgálatával foglalkoztunk.

A SerpinB2 fehérjét először csak a terhesség alatt megjelenő extracelluláris proteinként jellemezték, mely plazminogén aktivátorokat képes gátolni, nevezetesen az uPA (urokinase plasminogen activator) és tPA (tissue plasminogen activator) enzimeket ${ }^{135-140}$. Azóta számos sejttípusban, mint például monocita, makrofág, eozinofil, keratinocita, mikroglia, endoteliális, és epiteliális sejtben is kimutatták az SPB2 mRNS és fehérje szintjének növekedését intracellulárisan különböző faktorok és változások hatására ${ }^{143-149}$. Az SPB2 számos folyamatban vesz részt, például a szignál transzdukcióban, apoptózis gátlásában, makrofágok túlélését elősegítő folyamatokban, monocita és keratinocita sejtek differenciációjában, gyulladásos és immunfolyamatok szabályozásában ${ }^{150-157,199}$. Mindezek 
ellenére az SPB2 szerepe az UV sugárzás kiváltotta DNS hibajavítás folyamatában máig nem tanulmányozott terület.

Az előzetes microarray eredményeink arra utaltak, hogy Hker E6SFM sejtekben az SPB2 szerepet játszhat az UV sugárzás kiváltotta sejtválaszban. Annak érdekében, hogy ezen eredményeinket igazoljuk, kvantitatív real-time PCR (qPCR) módszerével vizsgáltuk az $S P B 2$ expresszió szintjének változását két eltérő bőr eredetű sejtvonalban. Azt tapasztaltuk, hogy UV kezelés hatására az SPB2 mRNS szintje megemelkedik a kontroll sejtekben mért mRNS szinthez képest. Eredményeink felvetették a kérdést, hogy az SPB2 mRNS szint emelkedése UV sugárzás hatására egy evolúciósan konzervált folyamat, vagy csak olyan sejtvonalakra jellemző, melyek normál körülmények között is érintkeznek az UV sugárzással. Ezért U2OS oszteoszarkóma sejteken is megismételtük a qPCR méréseket. Az expresszió értékeket ábrázolva hasonló lefutású kinetikát tapasztaltunk, mint melanoma sejtek esetében. Azonban a U2OS sejtvonalban mért mRNS szint emelkedés jóval mérsékeltebb volt, mint a bör eredetű sejtvonalaknál tapasztalt változás. Így arra a következtetésre jutottunk, hogy az SPB2 mRNS szintjének emelkedése UV sugárzás hatására egy konzervált folyamat, mely sejtválasz azonban a test perifériáján megtalálható sejtekben sokkal intenzívebb változásokat mutat.

Kimutattuk, hogy az UV kezelés nem csak a fehérje mennyiségét növeli meg, hanem sejten belüli lokalizációjának megváltozását is eredményezi, mivel az SPB2 föleg a citoplazmában található, de az UV károsodás sejtmagi felhalmozódást okozott. Az irodalomban a legtöbb leírás az SPB2 intracelluláris lokalizációjáról, a citoplazmában említi a fehérjét. Schroder és munkatársai például megfigyelték az SPB2 felhalmozódását a citoplazmában fertőzés vagy gyulladásos folyamatok eredményeként ${ }^{181}$. Azonban Lee és Yerbury humán, vese eredetű sejtekben kimutatták, hogy az SPB2-GFP fúziós fehérje mind a citoplazmában, mind a sejtmagban megfigyelhető ${ }^{182}$. Eredményeinkben azt tapasztaltuk, hogy az SPB2 fehérje szintje megemelkedik UV sugárzás következtében, valamint a szubcelluláris lokalizációja is megváltozik, ugyanis a citoplazmából a sejtmagba transzportálódik és feltételezhetően kötődik a sérült DNS régióhoz. Ezen eredményt sikerült CSK-immunhisztokémia segítségével is igazolnunk. Továbbá azt is megfigyeltük, hogy az SPB2 fókuszokat alakít ki a sejtmagban, mely utalhat a fehérje hibajavító lókuszokban történő megjelenésére, vagy egyéb, például transzkripciós blokk következtében kialakuló fehérje degradációs központokban való lokalizációjára is. Mivel mind a fehérjeszint emelkedést, illetve a sejten belüli lokalizáció változást sikerült kimutatni több sejttípusban, ezért feltételezzük, hogy ez 
egy általános, minden humán sejtben lejátszódó folyamat és nem kizárólag a bőrsejtekre jellemző mechanizmus.

Az UV sugárzás mellett a sejtekben található DNS-t más típusú DNS károsító ágensek is roncsolhatják. Következő lépésben azt vizsgáltuk, hogy az SPB2 fókuszokat alakít-e a sejtmagban oxidatív károsodást okozó $\mathrm{H}_{2} \mathrm{O}_{2}$, valamint kettős-szálú DNS törést okozó neocarzinostatin kezelés hatására. Eredményeink igazolták, hogy hasonlóan az UV sugárzáshoz, az oxidatív stressz hatására az SPB2 fókuszokat alakított ki a sejtmagban, azonban az NCS kezelésnél nem láttunk hasonló SPB2 felhalmozódást. Mindezen eredményekből arra következtettünk, hogy az SPB2 fehérje szintje megemelkedik és fókuszokat alakít ki a sejtmagban olyan stresszhatások következtében, melyekből származó DNS hibák a nukleotidokat érintik és javításuk gyors választ igényel. Ilyen DNS hibajavító útvonalak lehetnek a bázis kivágó hibajavítás (BER), valamint a nukleotid kivágó hibajavítás (NER). Azonban az irodalomból ismert, hogy azon hibák, melyek nem javítódnak ki a BER útvonal által, aktiválják a NER-t. Feltételezésünk szerint a nehezen kijavítható DNS hibák végeredményben a NER aktivációját okozzák és ezért látunk UV, illetve $\mathrm{H}_{2} \mathrm{O}_{2}$ kezelés hatására SPB2 szintemelkedést és sejtmagi fókuszok kialakulását, ezért feltételeztük, hogy az SPB2 fehérjének az UV indukálta NER útvonalban lehet szerepe.

Hipotézisünk alátámasztására UV kezelést követően CSK-immunfestéssel vizsgáltuk az SPB2 és számos, a NER útvonalban résztvevő Xeroderma pigmentosum (XP) fehérje funkcionális kapcsolatát. Azt tapasztaltuk, hogy az SPB2 nem lokalizálódik együtt a NER útvonal korai fázisában aktív XPC, illetve a késői fázisban müködő XPF fehérjével, de a NER útvonal középső szakaszában aktív, XPB fehérjével igen. A SPB2-XPB kapcsolata a következőképpen magyarázható: (I) Az SPB2 direkt módon, fizikálisan is kapcsolódva szabályozza az XPB müködését. Ezen feltételezést alátámaszthatja, hogy az SPB2 fehérjéről kimutatták, hogy több más Serpinnel egyetemben, chaperon aktivitással is rendelkezik, mellyel befolyásolhatja az XPB funkcióját ${ }^{200}$. (II) Továbbá az is előfordulhat, hogy az SPB2 proteáz inhibítor funkciója lévén közvetett módon befolyásolja az XPB aktivitását, például a hibajavításban résztvevő, a DNS-sel keresztkötött fehérjék eltávolításáért felelős proteázokat inaktiválhatja. A közelmúltban kimutatták, hogy a NER folyamatának finomszabályozásában részt vesz az UPS (ubiquitin-proteasome system) rendszer, valamint számos proteáz ${ }^{201-203}$. Lee és munkatársai pedig arról számoltak be, hogy neuronokban az SPB2 az UPS rendszerrel közreműködve akadályozza meg a fehérjék aggregációját ${ }^{182}$. Azonban a direkt kapcsolatot az SPB2 és a NER hibajavító folyamat között még nem sikerült 
bizonyítani. (III) Bár az XPB és az SPB2 fehérje egyidőben fordul elő a hibás DNS környékén, de funkcionális kapcsolat nem áll fenn köztük. Hipotéziseink igazolására első lépésben ko-immunprecipitációs eljárással vizsgáltuk az XPB-SPB2 kölcsönhatását. Az általunk használt alacsony sókoncentrációjú mosás ellenére sem tudtunk fizikai kapcsolatot kimutatni az SPB2 és az XPB fehérje között, amely alapján kizárható a hipotézisünk első pontja. Következő lépésként megvizsgáltuk, hogy az SPB2 és az XPB fehérje között van-e funkcionális kapcsolat, vagy az UV sugárzás hatására látott SPB2 és XPB ko-lokalizációs fókuszok csak a két fehérje egy időben és térben történő elöfordulását jelzik. Ennek tisztázására LacO technikát alkalmaztunk. Ezen rendszer használatával az XPB kihorgonyzását követően megfigyelhettük az SPB2 fehérje NER pre-incíziós komplexszel való ko-lokalizációját kezeletlen és UV kezelt sejtekben is. Ezen eredmények alátámasztják azon korábbi feltételezésünket, hogy UV sugárzás hatására az SPB2 a nukleotid kivágó hibajavítási fókuszokban jelenik meg, ahol az XPB faktorral ugyan fizikai kapcsolatba nem lép, de funkcionális együttmüködés tapasztalható közöttük, így az SPB2 feltehetőleg az UV indukált sejtválaszban szabályozó szerepet tölthet be. Továbbá vizsgáltuk, hogy a kimutatott funkcionális kölcsönhatásért az XPB fehérje mely régiója felelös. Azt találtuk, hogy az XPB C-terminális doménje önmagában nem képes a hibajavítási fókuszhoz vonzani az SPB2 fehérjét. Eredményeinkből egyértelmüen látható, hogy az SPB2 fehérjének a NER hibajavító útvonal középső szakaszában lehet szerepe, azonban nem zárható ki teljesen, hogy az SPB2 protein rendelkezik más funkcióval is a NER útvonal további szakaszaiban. Ilyen folyamat például a TC-NER hibafelismerési szakasza, illetve az RNS Polimeráz II elmozdítása a hibás DNS szakaszról (backtracking). Annak eldöntésére, hogy ezen lépésekben szerepe van-e az SPB2-nek, ko-immunprecipitációs kísérletben vizsgáltuk az elongáló Polimeráz II - SPB2 kölcsönhatást, azonban nem tudtunk interakciót kimutatni a két fehérje között. Ezzel az eljárással ugyan nem tudtuk teljesen kizárni az SPB2 lehetséges szerepét a TC-NER hibafelismerő szakaszában, hiszen csak azt igazoltuk, hogy nincs fizikai interakció az SPB2 és az S2P RPB1 között.

Nemrégiben arra derült fény, hogy az UPS rendszernek és specifikus proteázoknak igen nagyfokú szerepe van a NER útvonal korai szakaszainak finomszabályzásában 201-203. Azonban az UPS rendszer közremüködésének nem csak a NER fehérjék proteoszómális lebontása lehet az eredménye. Kimutatták, hogy a DDB-Cul4 E3 ubiquitin ligáz az USP7 deubiquitilázzal versengve szabályozza az XPC kötődésének erősségét a hibás DNS szakaszhoz ${ }^{43,48,187}$. Azonban az USP7 hatását a NER útvonalban később aktiválódó 
fehérjékre még nem vizsgálták, annak ellenére, hogy például az XPB és a 26S proteoszóma kapcsolatát már leírták ${ }^{204}$. Az SPB2 fehérjéről kimutatták, hogy az UPS rendszerrel áll kapcsolatban idegsejtekben. Az SPB2 hiányában az aggregálódott proteinek kompartmentalizációja sérül, mely az UPS rendszer meghibásodásához vezet. Továbbá Lee és munkatársai azt is kimutatták, hogy az SPB2 interakcióba lép az ubiquitilált fehérjékkel, de önmaga nem ubiquitilálódik ${ }^{182}$. Ezen eredmények felvetették a kérdést, hogy az SPB2 asszociációja a NER komplexszel ubiquitiláció által szabályozott-e. Az SPB2 és az ubiquitin közti interakció vizsgálatára szintén ko-immunprecipitációs kísérleteket végeztünk és sikerült kapcsolatot kimutatnunk az SPB2 és az Ub között UV kezelés hatására. Mindezen eredményekből feltételezzük, hogy az SPB2 fehérjének szerepe lehet a NER útvonal ubiquitiláció általi finomszabályozásában, melyet alátámaszt azon irodalmi adat, hogy az SPB2 az UPS rendszerrel is kapcsolatban áll ${ }^{182}$. Továbbá az irodalomban említett neuronokban kimutatott eredményekkel ellentétben az sem zárható ki, hogy a vizsgált U2OS sejtvonalban maga az SPB2 fehérje ubiquitilálódik UV sugárzás hatására, mely ezáltal a funkciójának módosításához vezet ${ }^{182}$.

Az irodalmi adatok alapján feltételezhető, hogy az SPB2 fehérjének szerepe lehet különböző tumorok kialakulásában, mint ahogy plazminogén inhibítor funkcióját említik emésztőrendszeri-, emlö-, vagy tüdőrákok esetében 158,159,161,205. Azonban az SPB2 mennyiségi hatásáról eltérő eredmények láttak napvilágot. Találunk példát az SPB2 emelkedett expressziójának a húgyhólyag tumorban szendevő páciensek vagy nyelőcső laphámrákkal diagnosztizált betegek túlélési arányára gyakorolt negatív hatásáról is ${ }^{189,190}$. Ezekkel ellentétes folyamatot írtak le emlö-, ill. hasnyálmirigy tumorok esetében, ahol a csökkent SPB2 expresszió hozható összefüggésbe az alacsony túlélési esélyekkel ${ }^{191-194}$. Mivel munkánk során kapcsolatot találtunk az SPB2 és a NER útvonal között, ezért megvizsgáltuk az SPB2 mennyiségi eloszlását bazális sejtes bőrtumorokból származó humán szövetmintákon. Bár az SPB2 fehérje mennyiségében nem, de sejten belüli eloszlásában különbséget tapasztaltunk a normál és tumoros szövetrészek között. Ép szövetrészekben az SPB2 a sejtmagban és a citoplazmában is egyaránt megtalálható, míg a minták tumoros szövetrészein az SPB2 lokalizációja csak a citoplazmára korlátozódott. Mindezen eredményekből arra a következtetésre jutottunk, hogy az SPB2 egy potenciálisan új szabályozó faktor az UV sugárzás indukálta javító mechanizmusban. Feltételezéseink szerint a tumoros sejtekben az SPB2 sejtmagba történő transzportja akadályozott, ezáltal a 
fehérje nem képes ellátni a feladatát a hibajavítási fókuszokban, emiatt a DNS javító mechanizmus hibát szenved, mely akár a mutációs ráta emelkedéséhez is vezethet.

Az SPB10 fehérje funkciója kevésbé jellemzett, irodalmi adatok szerint a mieloid leukémia sejtek proliferációjának elősegítéséről ismert normál körülmények között, míg növekedési faktorok hiányában a sejtek apoptózisát indukálja ${ }^{172}$. Az SPB10 szerepét az UV sugárzás hatására kialakuló sejtválaszban azonban még nem vizsgálták. Előzetes microarray eredményeink arra utaltak, hogy az SPB2 mellett az SPB10 is szerepet játszhat az UV sugárzás kiváltotta sejtválaszban Hker E6SFM sejtekben, hiszen az SerpinB10 gén expresszió növekedést mutatott UV kezelés hatására. Az előkísérletek validálására kvantitatív real-time PCR (qPCR) kísérletet végeztünk és kimutattuk, hogy UV sugárzás hatására az SPB10 mRNS szintje megemelkedett Hker E6SFM és további két bőr eredetü sejtvonalban. Következő lépésként megvizsgáltuk, hogy az SPB10 befolyásolja-e a sejtek túlélését UV sugárzás hatására. Azonban nem tapasztaltunk szignifikáns különbséget a túlélési arányban a kontroll és SPB10 csendesített kezeletlen és UV kezelt U2OS sejtek között.

Az eddigi eredményeink ellentmondásosak, mivel bár az SPB10 mRNS szintje emelkedik UV kezelés hatására, ami azt sugallja, hogy az UV károsodás indukálta sejtválaszban lehet szerepe, de ez a funkció nem esszenciális, mivel az SPB10 hiányában a sejtek képesek a DNS károsító kezelést túlélni. Az ellentmondás feloldására tanulmányoztuk, hogy az SPB10 hogyan befolyásolja az UV okozta DNS hibák javítását. U2OS sejtekben SPB10 siRNS csendesítést végeztünk, majd az SPB10 hiányos sejteket UV kezelésnek vetettük alá és az UV sugárzást követő DNS javítás hatékonyságát Comet-esszé segítségével vizsgáltuk. Azt tapasztaltuk, hogy UV kezelést követően az S-fázisú sejtekben az SPB10 csendesítés hatására sokkal gyorsabb a DNS hibák javítása, mint a kontroll sejtekben. Mindezen eredményekből azt a konklúziót vontuk le, hogy az SPB10 befolyásolja az UV sugárzás következtében kialakult DNS hibák javítását. Valószínüsítjük, hogy az SPB10 a DNS hibajavítást lassítja, így elősegítheti a precízebb, ám több időt igénylő javítás folyamatát replikálódó sejtekben, ezzel csökkentve a mutációk előfordulásának gyakoriságát. Ezen hipotézisünket igazolhatja, hogy az SPB10 génben előforduló SNP missense mutációkról kimutatták, hogy a japán populációban megjelenő prosztatarák kialakulásának kockázatát növelik ${ }^{171}$. 
A bemutatott eredményeinkböl arra következtettünk, hogy az SPB10 szerepet játszik az UV sugárzást követő DNS hibajavításban. Annak tisztázására, hogy ezen folyamat közvetlenül a kromatinon történik, vagy indirekt módon, egyéb fehérjéken keresztül, koimmunprecipitációs eljárást alkalmaztunk, melynek során vizsgáltuk az SPB10 és a H3 fehérje kapcsolatát. Kísérletünk eredményéből kiderül, hogy az SPB10 kölcsönhat a H3 fehérjével. Ezen fizikai interakció UV kezelés hatására erősödik a két fehérje között. Eredményeink alátámasztják korábbi hipotézisünket, mely szerint az SPB10 fehérje részt vesz az UV sugárzás hatására képződött DNS hibák javításának folyamatában.

Összefoglalásként elmondható, hogy a SerpinB fehérjecsalád három tagjánál is új funkciót azonosítottunk, mivel kimutattuk, hogy a SerpinB2, SerpinB10 és SerpinB13 is szerepet játszik az UV kiváltotta azonnali sejtválaszban. Dolgozatomban két fehérjével, az SPB2 és SPB10 vizsgálatával foglalkoztam. Kísérleti eredményeinkből levont következtetéseink alapján elmondható, hogy UV sugárzás hatására emelkedik az expressziójuk, illetve mindkét fehérjéről kimutattuk, hogy UV sugárzás hatására a kromatin kötött frakcióban dúsulnak fel, amely arra utalhat, hogy az SPB2 és SPB10 a DNS hibajavítás finomszabályozásában vehet részt. A proteázok szerepéről különböző hibajavítási útvonalakban már számos tanulmány beszámolt, és az újabb eredmények arra is rávilágítanak, hogy a proteáz inhibítorok is befolyásolhatják a DNS hibajavító útvonalakat. Eredményeinkből azt feltételezzük, hogy mindkét fehérje az UV sugárzás hatására bekövetkező hibajavításban játszik szerepet: az SPB2 fehérjének a NER útvonalban, az XPB aktivitását követő folyamatok regulációjában lehet szerepe, míg az SPB10 az UV kiváltotta replikációs stresszben müködhet közre. 


\section{Köszönetnyilvánítás}

Köszönettel tartozom témavezetőmnek, Prof. Dr. Boros Imre Miklósnak, aki lehetőséget biztosított számomra, hogy $\mathrm{PhD}$ hallgatóként a Biokémiai és Molekuláris Biológiai Tanszéken dolgozhassak és szakmai tudásával segítette munkámat.

Szeretném köszönetemet kifejezni témavezetőmnek, Dr. habil. Pankotai Tibornak, hogy tanácsaival, irányításával, valamint áldozatos munkájával hozzájárult fejlődésemhez és szakmai elömenetelemhez. Köszönöm türelmét és bizalmát irányomban, valamint a lehetőséget, hogy kutatócsoportja tagja lehettem.

Köszönöm Dr. Borsos Barbara Nikolettnek, Dr. Újfaludi Zsuzsannának és Dr. Páhi Zoltán Gábornak a segítségüket, támogatásukat és hasznos tanácsaikat, melyet munkám során nyújtottak, valamint a Genom Integritás és DNS hibajavító Kutatócsoport minden tagjának a segítségüket.

Köszönöm Ökrösné Katalinnak és Pataki Edinának a kísérletekben nyújtott segítségüket és támogatásukat. Köszönöm a Biokémiai és Molekuláris Biológiai Tanszék összes jelenlegi és volt munkatársának, hogy munkájukkal támogattak.

Köszönöm Dr. Frederic Coinnak és Dr. Nagy Zitának a lehetőséget, hogy a „Genom expression and repair” kutatócsoportnál végezhettem kísérleteim egy részét, valamint szakmai segítségüket ez idő alatt.

Köszönöm Dr. Mórocz Mónikának a Comet-esszé kísérletekben nyújtott segítségét.

Köszönöm Dr. Sükösd Farkasnak, Dr. Bíró Tamásnak, Dr. Buzás Krisztinának és Dr. Kovács Ilonának a bazális sejtes karcinóma mintákkal kapcsolatos kísérletekben nyújtott segítségüket.

Nem utolsó sorban köszönöm családomnak, hogy mindvégig mellettem álltak és támogattak. 


\section{A doktori értekezés összefoglalója}

Az UV sugárzás, mint mindennapjainkat érintő környezeti faktor, és az általa kiváltott DNS károsodások, illetve ezekre adott sejtválasz egy napjainkban intenzíven tanulmányozott kutatási terület, hiszen a nem tökéletesen, vagy nem megfelelő sebességgel kijavított hibák tumorképződéshez vezethetnek. Kutatócsoportunkkal nemrégiben közöltünk egy tanulmányt, melyben egy immortalizált keratinocita sejtvonal, a Hker E6SFM UV sugárzásra adott génexpresszió változásait vizsgáltuk kontroll és UV sugárzással kezelt sejtek mRNS profiljának összehasonlításával. Az UV kezelés hatására megemelkedett transzkripciós aktivitású gének közül kimutattuk a Serpin fehérjecsalád több tagját is, melyek szerepét korábban még nem vizsgálták a DNS károsodás hatására indukálódó sejtválaszban. Disszertációm fó célja az UV károsodás indukciója után a két legerősebb génexpresszió változást mutató SerpinB2 (SPB2) és SerpinB10 (SPB10) génekről termelődő fehérjék funkciójának jellemzése volt.

A SerpinB2 plazminogén aktivátorokat képes gátolni, nevezetesen az uPA és tPA enzimeket. Azóta számos sejttípusban kimutatták az SPB2 mRNS és fehérje szintjének növekedését intracellulárisan, különböző faktorok és változások hatására. Ezért az SPB2 számos folyamatban részt vesz, például a szignál transzdukcióban, apoptózis gátlásában, makrofágok túlélését elősegítő folyamatokban, monocita és keratinocita sejtek differenciációjában, gyulladásos és immunfolyamatok szabályozásában.

Ph.D. munkám során sikerült kimutatnunk, hogy UV kezelés hatására az SPB2 mRNS és fehérje szintje is megemelkedik számos bőr eredetű sejtvonalban. U2OS oszteoszarkóma sejtvonalban szintén igazoltuk az SPB2 mRNS szint emelkedését UV kezelés hatására, azonban ezen változás kisebb mértékü volt, mint a bőr eredetü sejtvonalak esetében. Így arra a következtetésre jutottunk, hogy az SPB2 expresszió emelkedés UV sugárzás hatására egy általános, evolúciósan konzervált folyamat, mely sejtválasz azonban a bőrsejtekben sokkal intenzívebb hatású. Továbbá azt is megfigyeltük, hogy az SPB2 fehérje UV sugárzás hatására a citoplazmából a sejtmagba transzportálódik és ott fókuszokat alakít ki, mely utalhat a fehérje hibajavító lókuszokban történő megjelenésére. Kimutattuk azt is, hogy ezt a folyamatot nem csak az UV károsodás aktiválja, hanem megfigyelhető $\mathrm{H}_{2} \mathrm{O}_{2}$ kezelés hatására is, azonban NCS kezelést követően nem tapasztaltunk ilyen változásokat. Mindezen eredményekből arra következtettünk, hogy az SPB2 fehérje aktivációja olyan stresszhatások 
következménye lehet, melyekből származó DNS hibák a nukleotidokat érintik és javításuk gyors választ igényel.

A nukleotidokat ért hibák egyik fö javító mechanizmusa a nukleotid kivágó hibajavítás. Kísérleteinkben megfigyeltük, hogy UV kezelést követően az SPB2 fehérje ko-lokalizálódik a NER útvonal középső szakaszában aktív XPB fehérjével. Azonban az SPB2 sem az XPC, XPF, illetve az elongáló Polimeráz II (S2P RPB1) sem mutat ko-lokalizációt, mely eredmény miatt feltételezhető, hogy az SPB2 nem szükséges a NER korai hibafelismerési, valamint késői szakaszában, illetve az RNS Polimeráz II elmozdításának (backtracking) szabályzásában sem. Bár kísérleteinkben nem tudtunk fizikai kapcsolatot kimutatni, funkcionális kapcsolatot találtunk az SPB2 és az XPB fehérje között. LacO rendszer használatával az XPB kihorgonyzását követően megfigyelhettük az SPB2 fehérje NER preincíziós komplexszel való ko-lokalizációját kezeletlen és UV kezelt sejtekben is. Mindezen eredményekböl arra következtettünk, hogy az SPB2 az UV indukált sejtválaszban részt vevő potenciális regulátor fehérje lehet. Egyes folyamatok finomszabályozásában legtöbbször poszt-transzlációs módosítások - mint például az ubiquitiláció-kapcsolt szignalizáció játszanak regulátor szerepet. Sikerült kapcsolatot kimutatnunk az SPB2 és az UV kezelés hatására kialakuló ubiquitiláció-függő útvonal között, amely alapján feltételeztük, hogy az SPB2 fehérjének szerepe lehet a NER ubiquitiláció általi finomszabályozásában.

Az irodalomból ismert, hogy a NER hibajavító útvonal bármely tagjának mutációja súlyos bőrtumorok kialakulásához vezethet, ezért vizsgáltuk az SPB2 jelenlétét és szintjét bazális sejtes börtumorokból származó humán szövetmintákon. Az SPB2 fehérje mennyiségében nem, de sejten belüli eloszlásában különbséget találtunk a normál és a tumoros szövetrészek között. Ép szövetrészekben az SPB2 a sejtmagban és a citoplazmában helyezkedik el, míg a minták tumoros szövetrészeiben az SPB2 csak a citoplazmában lokalizálódott. Mindezen eredményekböl arra a következtetésre jutottunk, hogy az SPB2 egy potenciálisan új szabályzó faktor az UV sugárzás indukálta javító mechanizmusban. Feltételezéseink szerint a tumoros sejtekben az SPB2 sejtmagba történő transzportja akadályozott, emiatt a DNS javító mechanizmus nem müködik megfelelően, mely akár a mutációs ráta emelkedéséhez is vezethet.

Irodalmi adatok alapján elmondható, hogy az SPB10 fehérje szabályozza a mieloid leukémia sejtek proliferációját, illetve indukálhatja azok apoptózisát is a növekedési faktorok jelenlététől függően. Korábbi microarray eredményeink arra utaltak, hogy az Hker E6SFM 
sejtekben az SPB2 mellett az SPB10 is szerepet játszhat az UV sugárzás kiváltotta sejtválaszban. Annak érdekében, hogy tanulmányozzuk az SPB10 szerepét UV sugárzást követően, első lépésként kvantitatív real-time PCR (qPCR) módszert alkalmaztunk és azt tapasztaltuk, hogy UV sugárzás hatására az SPB10 mRNS szintje megemelkedett Hker E6SFM, A375 melanoma és HaCaT sejtekben. Továbbá megállapítottuk, hogy az SPB10 siRNS csendesítése nem befolyásolja a sejtek UV sugárzást követő túlélését. Az előző eredményeink arra utaltak, hogy SPB10 is szerepet játszhat az UV sugárzás hatására kialakult sejtválaszban, de a fehérje hiánya nem befolyásolja a sejtek UV utáni túlélését. Ezért következő lépésként vizsgáltuk, hogy az SPB10 hogyan játszhat szerepet az UV okozta DNS hibák javításában. Comet-esszét alkalmazva kimutattuk, hogy SPB10 csendesített Sfázisú sejtekben UV kezelés hatására sokkal gyorsabb a DNS hibák javítása, mint a nem csendesített sejtekben. Ebböl arra következtettünk, hogy az SPB10 csendesített sejtekben feltételezhetően gyorsabb a hibajavítás. Valószínüsítjük, hogy az SPB10 a DNS hibajavítást lassítja, így elösegítheti a precízebb, ám több időt igénylö javítás folyamatát replikálódó sejtekben, ezzel csökkentve a mutációk elöfordulásának gyakoriságát. Végül igazoltuk, hogy az SPB10 kölcsönhat a H3 fehérjével és az interakció a két fehérje között UV kezelés hatására erősödik.

Összefoglalásként elmondható, hogy a SerpinB fehérjecsalád három tagja, a SerpinB2, a SerpinB10 és a SerpinB13 is szerepet játszik az UV kiváltotta sejtválaszban. Dolgozatomban két fehérje, az SPB2 és az SPB10 vizsgálatával foglalkoztam. Eredményeink alapján elmondható róluk, hogy UV sugárzást követően megemelkedik az expressziójuk, és a kromatin kötött frakcióban dúsulnak fel. Eredményeinkből arra következtetünk, hogy az SPB2 és SPB10 az UV sugárzás hatására bekövetkező DNS hibajavítás finomszabályzásában vesznek részt. Feltételezéseink szerint az SPB2 fehérjének a NER útvonalban, az XPB aktivitását követő folyamatok regulációjában lehet szerepe, míg az SPB10 az UV kiváltotta replikációs stressz feloldásában müködhet közre. 


\section{Summary}

Ultraviolet light-induced DNA damage response is an extensively studied process. However, several proteins involved in DNA damage repair have been already identified, the entire repair cascade and the protein-protein interactions have remained unexplored. Our recently published data performed on an immortalized keratinocyte Hker E6SFM cell line, have indicated that several members of the Serpin protein family show elevated expression upon UV irradiation. This high-throughput screen prompted us to hypothesize a still uncharacterized, potential role of the Serpin family during the process of DNA repair. Based on these preliminary data, during my $\mathrm{PhD}$ work, I have characterized the function of the two most dramatically upregulated genes, SerpinB2 (SPB2) and SerpinB10 (SPB10) following UV irradiation.

SPB2 protein was originally identified as an extracellular inhibitor of the plasminogen activator uPA and tPA enzymes during pregnancy. Since then, the upregulation of SPB2 mRNA and protein levels has been confirmed in several cell types and it has been also reported that SPB2 is involved in numerous cellular processes, such as signal transduction, inhibition of apoptosis, macrophage survival, monocyte and keratinocyte differentiation, regulation of inflammatory and immune processes.

Our data demonstrated in various cell types that UV irradiation resulted in an increase on both $S P B 2$ mRNA and protein levels. We detected the strongest activation of SPB2 in Hker E6SFM keratinocyte and A375 melanoma cells following UV irradiation. U2OS cells also showed similar, but milder increase in the mRNA level of SPB2. It could be explained by evolutionary conserved mechanisms in response to UV irradiation, which was a more robust process in keratinocyte cells. In addition, we also proved that UV irradiation triggered the nuclear transport of SPB2, where it appeared at discrete nuclear foci at the sites of DNA damage. This phenomenon was also observed following $\mathrm{H}_{2} \mathrm{O}_{2}$, but not with NCS treatment. These might indicate that the activation of SPB2 in response to UV irradiation is a common mechanism among different cell types owing tissue-specific repair mechanisms. Consequently, SPB2 protein might play role in the fine-tune regulation of nucleotide excision repair pathway, but it is presumably not involved in DNA double-strand break repair.

To reveal the possible role of SPB2 protein in UV-induced repair process, we examined the co-localization between SPB2 and XP proteins involved in NER pathway. Our data showed 
that SPB2 co-localized with XPB protein upon UV irradiation. Furthermore, we also found that neither XPC, nor XPF co-localized with SPB2 following UV irradiation. Furthermore, we did not show interaction between SPB2 and the elongating RNA Polymerase II (S2P RPB1), by which we excluded the involvement of SPB2 in DNA-damage recognition or in the backtracking steps of the TC-NER pathway. However, we did not detect physical interaction between $\mathrm{XPB}$ and $\mathrm{SPB} 2$, an indirect connection between them cannot be justified. Finally, we showed that XPB tethering resulted in the recruitment of SPB2 protein to the repair foci suggesting that SPB2 could be a potential regulator of the UV-induced cellular processes, which might be recruited to the damaged sites during the middle steps of the NER pathway.

In addition, we detected connection between SPB2 protein and ubiquitin residues following UV treatment. This result suggests that SPB2 can play an important role in the ubiquitinmediated fine-tune regulation of the NER pathway.

Since mutations of any member of the NER pathway can lead to skin tumorigenesis, we investigated the subcellular localization and the possible changes in the level of SPB2 protein in human basal cell carcinoma tissues. Although we did not observe any significant differences in the protein level of SPB2 in the tumorous part of the tissue compared to its normal part, we found that SPB2 protein localized both in the cytoplasm and in the nucleus. In the tumorous part of the tissue, SPB2 was mainly detected in the cytoplasm, while in the normal part it was found in both cellular compartments. Our data suggest that beside the inhibition of plasminogen activators, SPB2 might have additional function in tumour cells. These results underlie the hypothesis that in non-tumorous cells, SPB2 promotes the repair process upon UV irradiation in the nucleus, thereby decreasing the mutation rate. On the other hand, in tumorous cells, SPB2 cannot be translocated to the nucleus to be involved in the repair process, hereby elevating the mutation rate. Based on our results we conclude that SPB2 protein is a potential player in UV-induced NER pathway by regulating the removal of the NER complex from the damaged DNA, therefore malfunction of SPB2 can result in tumour progression.

SPB10 is a redox-sensitive nuclear Serpin that promotes proliferation or apoptosis of leukaemia cells, depending on the availability of growth factors. The primary screen also suggested that beside SPB2, SPB10 could also play a role in the UV-induced cellular processes. During my thesis work, my second project was focused on the investigation of that uncharacterized function of SPB10 following UV irradiation. 
As a first step, we verified the results of the microarray experiment by using quantitative real-time PCR (qPCR) method and we found that the mRNA level of SPB10 was elevated upon UV irradiation in Hker E6SFM and also in two additional skin-derived cell lines (A375 melanoma and HaCaT keratinocytes). As a following step, we studied whether SPB10 played a role in NER, but we found that siRNA silencing of SPB10 had no effect on cell viability upon UV irradiation. Based on these, we concluded that SPB10 could play a role in the UV-induced cellular response, but it had no indispensable function in this process. Additionally, we investigated whether SPB10 was involved in the UV-triggered DNA repair mechanism. Using Comet assay, we showed that the process of DNA repair was accelerated in SPB10-silenced S-phase cells compared to the control. We conclude that SPB10 influences the repair of the UV-induced DNA damages, presumably by slowing down that process in replicating cells, which facilitates a more precise, but time-consuming repair mechanism by further reducing the mutation rate. Finally, we demonstrate that SPB10 interacts with $\mathrm{H} 3$ and this physical interaction is enhanced following UV irradiation.

In conclusion, I demonstrated that three members of the SerpinB protein family (SerpinB2, SerpinB10 and SerpinB13) might have been involved in the UV-induced cellular response and I further characterized the regulatory role of SPB2 and SPB10. Based on experimental evidences we established that the expression of these two Serpins was increased upon UV irradiation and we also showed that both proteins were enriched in the chromatin-bound fraction after UV irradiation. Eventually, our results suggest that SPB2 and SPB10 are involved in the fine-tune regulation of the DNA repair processes. We assume that SPB2 protein can play a pivotal role in the regulation of NER pathway after the activation of XPB protein, whereas SPB10 can participate in the resolution of UV-induced replication stress. 


\section{Irodalomjegyzék}

1. Setlow, R. B. The wavelengths in sunlight effective in producing skin cancer: a theoretical analysis. Proc. Natl. Acad. Sci. U. S. A. 71, 3363-6 (1974).

2. Godar, D. UV Doses Worldwide. Photochem. Photobiol. 81, 736-49 (2005).

3. Kielbassa, C., Roza, L. \& Epe, B. Wavelength dependence of oxidative DNA damage induced by UV and visible light. Carcinogenesis 18, 811-6 (1997).

4. Ravanat, J. L., Douki, T. \& Cadet, J. Direct and indirect effects of UV radiation on DNA and its components. J. Photochem. Photobiol. B. 63, 88-102 (2001).

5. Henriksen, T., Dahlback, A., Larsen, S. H. H. \& Moan, J. ULTRAVIOLETRADIATION and SKIN CANCER. EFFECT OF AN OZONE LAYER DEPLETION. Photochem. Photobiol. 51, 579-582 (1990).

6. Epstein, J. H. Photocarcinogenesis, skin cancer, and aging. J. Am. Acad. Dermatol. 9, 487-502 (1983).

7. de Gruijl, F. R., van Kranen, H. J. \& Mullenders, L. H. UV-induced DNA damage, repair, mutations and oncogenic pathways in skin cancer. J. Photochem. Photobiol. B. 63, 19-27 (2001).

8. Gange, R. W. \& Rosen, C. F. UVA effects on mammalian skin and cells. Photochem. Photobiol. 43, 701-5 (1986).

9. Nomura, T. et al. Induction of cancer, actinic keratosis, and specific p53 mutations by UVB light in human skin maintained in severe combined immunodeficient mice. Cancer Res. 57, 2081-4 (1997).

10. Rünger, T. M. \& Kappes, U. P. Mechanisms of mutation formation with long-wave ultraviolet light (UVA). Photodermatol. Photoimmunol. Photomed. 24, 2-10 (2008).

11. de Gruijl, F. R. Photocarcinogenesis: UVA vs UVB. Methods Enzymol. 319, 359-66 (2000).

12. Kabuyama, Y., Homma, M. K., Kurosaki, T. \& Homma, Y. Early signaling events induced by 280-nm UV irradiation. Eur. J. Biochem. 269, 664-670 (2002).

13. Armstrong, B. K. \& Kricker, A. The epidemiology of UV induced skin cancer. $J$. 
Photochem. Photobiol. B. 63, 8-18 (2001).

14. Boukamp, P. UV-induced Skin Cancer: Similarities - Variations. Durch UVStrahlung induzierte Hauttumore: Gemeinsamkeiten - Unterschiede. J. der Dtsch. Dermatologischen Gesellschaft 3, 493-503 (2005).

15. Swenberg, J. A. et al. Endogenous versus Exogenous DNA Adducts: Their Role in Carcinogenesis, Epidemiology, and Risk Assessment. Toxicol. Sci. 120, S130-S145 (2011).

16. Jackson, S. P. \& Bartek, J. The DNA-damage response in human biology and disease. Nature 461, 1071-1078 (2009).

17. Marteijn, J. A., Lans, H., Vermeulen, W. \& Hoeijmakers, J. H. J. Understanding nucleotide excision repair and its roles in cancer and ageing. Nat. Rev. Mol. Cell Biol. 15, 465-481 (2014).

18. Sugasawa, K. et al. Xeroderma pigmentosum group C protein complex is the initiator of global genome nucleotide excision repair. Mol. Cell 2, 223-32 (1998).

19. Masutani, C. et al. Purification and cloning of a nucleotide excision repair complex involving the xeroderma pigmentosum group $\mathrm{C}$ protein and a human homologue of yeast RAD23. EMBO J. 13, 1831-43 (1994).

20. Nishi, R. et al. Centrin 2 Stimulates Nucleotide Excision Repair by Interacting with Xeroderma Pigmentosum Group C Protein. Mol. Cell. Biol. 25, 5664-5674 (2005).

21. Sugasawa, K. et al. A multistep damage recognition mechanism for global genomic nucleotide excision repair. Genes Dev. 15, 507-521 (2001).

22. Maillard, O., Camenisch, U., Clement, F. C., Blagoev, K. B. \& Naegeli, H. DNA repair triggered by sensors of helical dynamics. Trends Biochem. Sci. 32, 494-499 (2007).

23. Min, J.-H. \& Pavletich, N. P. Recognition of DNA damage by the Rad4 nucleotide excision repair protein. Nature 449, 570-575 (2007).

24. Reardon, J. T. \& Sancar, A. Recognition and repair of the cyclobutane thymine dimer, a major cause of skin cancers, by the human excision nuclease. Genes Dev. 17, 25392551 (2003). 
25. Scrima, A. et al. Structural Basis of UV DNA-Damage Recognition by the DDB1DDB2 Complex. Cell 135, 1213-1223 (2008).

26. Wakasugi, M. et al. DDB Accumulates at DNA Damage Sites Immediately after UV Irradiation and Directly Stimulates Nucleotide Excision Repair. J. Biol. Chem. 277, 1637-1640 (2002).

27. Chu, G. \& Chang, E. Xeroderma pigmentosum group E cells lack a nuclear factor that binds to damaged DNA. Science 242, 564-7 (1988).

28. Groisman, R. et al. The ubiquitin ligase activity in the DDB2 and CSA complexes is differentially regulated by the COP9 signalosome in response to DNA damage. Cell 113, 357-67 (2003).

29. Duda, D. M. et al. Structural Insights into NEDD8 Activation of Cullin-RING Ligases: Conformational Control of Conjugation. Cell 134, 995-1006 (2008).

30. Hannah, J. \& Zhou, P. Regulation of DNA damage response pathways by the cullinRING ubiquitin ligases. DNA Repair (Amst). 8, 536-543 (2009).

31. Kapetanaki, M. G. et al. The DDB1-CUL4ADDB2 ubiquitin ligase is deficient in xeroderma pigmentosum group $\mathrm{E}$ and targets histone $\mathrm{H} 2 \mathrm{~A}$ at UV-damaged DNA sites. Proc. Natl. Acad. Sci. U. S. A. 103, 2588-93 (2006).

32. Lan, L. et al. Monoubiquitinated histone H2A destabilizes photolesion-containing nucleosomes with concomitant release of UV-damaged DNA-binding protein E3 ligase. J. Biol. Chem. 287, 12036-49 (2012).

33. Wang, $\mathrm{H}$. et al. Histone $\mathrm{H} 3$ and $\mathrm{H} 4$ Ubiquitylation by the CUL4-DDB-ROC1 Ubiquitin Ligase Facilitates Cellular Response to DNA Damage. Mol. Cell 22, 383394 (2006).

34. Sugasawa, K. et al. UV-Induced Ubiquitylation of XPC Protein Mediated by UVDDB-Ubiquitin Ligase Complex. Cell 121, 387-400 (2005).

35. Scrima, A. et al. Detecting UV-lesions in the genome: The modular CRL4 ubiquitin ligase does it best! FEBS Lett. 585, 2818-2825 (2011).

36. van Cuijk, L., Vermeulen, W. \& Marteijn, J. A. Ubiquitin at work: The ubiquitous regulation of the damage recognition step of NER. Exp. Cell Res. 329, 101-109 
(2014).

37. Pines, A. et al. PARP1 promotes nucleotide excision repair through DDB2 stabilization and recruitment of ALC1. J. Cell Biol. 199, 235-49 (2012).

38. Zhang, L., Lubin, A., Chen, H., Sun, Z. \& Gong, F. The deubiquitinating protein USP24 interacts with DDB2 and regulates DDB2 stability. Cell Cycle 11, 4378-4384 (2012).

39. Pines, A. et al. PARP1 promotes nucleotide excision repair through DDB2 stabilization and recruitment of ALC1. J. Cell Biol. 199, 235-249 (2012).

40. Han, C. et al. UV radiation-induced SUMOylation of DDB2 regulates nucleotide excision repair. Carcinogenesis 38, 976-985 (2017).

41. Robu, M. et al. Role of poly(ADP-ribose) polymerase-1 in the removal of UVinduced DNA lesions by nucleotide excision repair. Proc. Natl. Acad. Sci. 110, 16581663 (2013).

42. Tsuge, M. et al. SUMOylation of damaged DNA-binding protein DDB2. Biochem. Biophys. Res. Commun. 438, 26-31 (2013).

43. He, J. et al. Ubiquitin-specific Protease 7 Regulates Nucleotide Excision Repair through Deubiquitinating XPC Protein and Preventing XPC Protein from Undergoing Ultraviolet Light-induced and VCP/p97 Protein-regulated Proteolysis. J. Biol. Chem. 289, 27278-27289 (2014).

44. van Cuijk, L. et al. SUMO and ubiquitin-dependent XPC exchange drives nucleotide excision repair. Nat. Commun. 6, 7499 (2015).

45. Akita, M. et al. SUMOylation of xeroderma pigmentosum group C protein regulates DNA damage recognition during nucleotide excision repair. Sci. Rep. 5, 10984 (2015).

46. Poulsen, S. L. et al. RNF111/Arkadia is a SUMO-targeted ubiquitin ligase that facilitates the DNA damage response. J. Cell Biol. 201, 797-807 (2013).

47. Vertegaal, A. C. O. Small ubiquitin-related modifiers in chains. Biochem. Soc. Trans. 35, 1422-3 (2007).

48. Wang, Q.-E. et al. DNA repair factor XPC is modified by SUMO-1 and ubiquitin 
following UV irradiation. Nucleic Acids Res. 33, 4023-4034 (2005).

49. Hoege, C., Pfander, B., Moldovan, G.-L., Pyrowolakis, G. \& Jentsch, S. RAD6dependent DNA repair is linked to modification of PCNA by ubiquitin and SUMO. Nature 419, 135-141 (2002).

50. Desterro, J. M. ., Rodriguez, M. S. \& Hay, R. T. SUMO-1 Modification of IкB $\alpha$

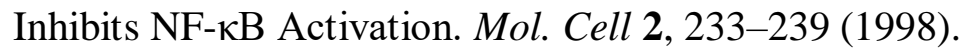

51. Lin, X., Liang, M., Liang, Y.-Y., Brunicardi, F. C. \& Feng, X.-H. SUMO-1/Ubc9 promotes nuclear accumulation and metabolic stability of tumor suppressor Smad4. J. Biol. Chem. 278, 31043-8 (2003).

52. Lee, P. S. W., Chang, C., Liu, D. \& Derynck, R. Sumoylation of Smad4, the common Smad mediator of transforming growth factor-beta family signaling. J. Biol. Chem. 278, 27853-63 (2003).

53. Lafrance-Vanasse, J., Arseneault, G., Cappadocia, L., Legault, P. \& Omichinski, J. G. Structural and functional evidence that $\operatorname{Rad} 4$ competes with $\operatorname{Rad} 2$ for binding to the Tfb1 subunit of TFIIH in NER. Nucleic Acids Res. 41, 2736-2745 (2013).

54. Okuda, M., Kinoshita, M., Kakumu, E., Sugasawa, K. \& Nishimura, Y. Structural Insight into the Mechanism of TFIIH Recognition by the Acidic String of the Nucleotide Excision Repair Factor XPC. Structure 23, 1827-1837 (2015).

55. Puumalainen, M.-R. et al. Chromatin retention of DNA damage sensors DDB2 and XPC through loss of p97 segregase causes genotoxicity. Nat. Commun. 5, 3695 (2014).

56. Rüthemann, P., Balbo Pogliano, C. \& Naegeli, H. Global-genome Nucleotide Excision Repair Controlled by Ubiquitin/Sumo Modifiers. Front. Genet. 7, 68 (2016).

57. Mellon, I., Spivak, G. \& Hanawalt, P. C. Selective removal of transcription-blocking DNA damage from the transcribed strand of the mammalian DHFR gene. Cell $\mathbf{5 1}$, 241-9 (1987).

58. Bohr, V. A., Smith, C. A., Okumoto, D. S. \& Hanawalt, P. C. DNA repair in an active gene: removal of pyrimidine dimers from the DHFR gene of $\mathrm{CHO}$ cells is much more efficient than in the genome overall. Cell 40, 359-69 (1985). 
59. Xu, J. et al. Structural basis for the initiation of eukaryotic transcription-coupled DNA repair. Nature 551, 653-657 (2017).

60. Fousteri, M., Vermeulen, W., van Zeeland, A. A. \& Mullenders, L. H. F. Cockayne Syndrome A and B Proteins Differentially Regulate Recruitment of Chromatin Remodeling and Repair Factors to Stalled RNA Polymerase II In Vivo. Mol. Cell 23, 471-482 (2006).

61. Schwertman, P., Lagarou, A., Dekkers, D., ... A. R.-N. \& 2012, undefined. UVsensitive syndrome protein UVSSA recruits USP7 to regulate transcription-coupled repair. nature.com

62. Okuda, M., Nakazawa, Y., Guo, C., Ogi, T. \& Nishimura, Y. Common TFIIH recruitment mechanism in global genome and transcription-coupled repair subpathways. Nucleic Acids Res. 45, 13043-13055 (2017).

63. Tornaletti, S., Reines, D. \& Hanawalt, P. C. Structural characterization of RNA polymerase II complexes arrested by a cyclobutane pyrimidine dimer in the transcribed strand of template DNA. J. Biol. Chem. 274, 24124-30 (1999).

64. Liu, X., Li, M., Xia, X., Li, X. \& Chen, Z. Mechanism of chromatin remodelling revealed by the Snf2-nucleosome structure. Nature 544, 440-445 (2017).

65. Marteijn, J. A., Hoeijmakers, J. H. J. \& Vermeulen, W. Check, Check ...Triple Check: Multi-Step DNA Lesion Identification by Nucleotide Excision Repair. Mol. Cell 59, 885-886 (2015).

66. Sigurdsson, S., Dirac-Svejstrup, A. B. \& Svejstrup, J. Q. Evidence that Transcript Cleavage Is Essential for RNA Polymerase II Transcription and Cell Viability. Mol. Cell 38, 202-210 (2010).

67. Wilson, M. D., Harreman, M. \& Svejstrup, J. Q. Ubiquitylation and degradation of elongating RNA polymerase II: The last resort. Biochim. Biophys. Acta - Gene Regul. Mech. 1829, 151-157 (2013).

68. Woudstra, E. C. et al. A Rad26-Def1 complex coordinates repair and RNA pol II proteolysis in response to DNA damage. Nature 415, 929-933 (2002).

69. Coin, F., Oksenych, V. \& Egly, J.-M. Distinct Roles for the XPB/p52 and XPD/p44 Subcomplexes of TFIIH in Damaged DNA Opening during Nucleotide Excision 
Repair. Mol. Cell 26, 245-256 (2007).

70. Oksenych, V., de Jesus, B. B., Zhovmer, A., Egly, J.-M. \& Coin, F. Molecular insights into the recruitment of TFIIH to sites of DNA damage. EMBO J. 28, 2971-2980 (2009).

71. Winkler, G. S. et al. TFIIH with inactive XPD helicase functions in transcription initiation but is defective in DNA repair. J. Biol. Chem. 275, 4258-66 (2000).

72. Sugasawa, K., Akagi, J., Nishi, R., Iwai, S. \& Hanaoka, F. Two-Step Recognition of DNA Damage for Mammalian Nucleotide Excision Repair: Directional Binding of the XPC Complex and DNA Strand Scanning. Mol. Cell 36, 642-653 (2009).

73. Camenisch, U., Dip, R., Schumacher, S. B., Schuler, B. \& Naegeli, H. Recognition of helical kinks by xeroderma pigmentosum group A protein triggers DNA excision repair. Nat. Struct. Mol. Biol. 13, 278-284 (2006).

74. Fan, L. et al. XPD Helicase Structures and Activities: Insights into the Cancer and Aging Phenotypes from XPD Mutations. Cell 133, 789-800 (2008).

75. Wolski, S. C. et al. Crystal Structure of the FeS Cluster-Containing Nucleotide Excision Repair Helicase XPD. PLoS Biol. 6, e149 (2008).

76. Pugh, R. A., Wu, C. G. \& Spies, M. Regulation of translocation polarity by helicase domain 1 in SF2B helicases. EMBO J. 31, 503-514 (2012).

77. Mathieu, N., Kaczmarek, N., Rüthemann, P., Luch, A. \& Naegeli, H. DNA Quality Control by a Lesion Sensor Pocket of the Xeroderma Pigmentosum Group D Helicase Subunit of TFIIH. Curr. Biol. 23, 204-212 (2013).

78. Liu, H. et al. Structure of the DNA Repair Helicase XPD. Cell 133, 801-812 (2008).

79. de Laat, W. L. et al. DNA-binding polarity of human replication protein A positions nucleases in nucleotide excision repair. Genes Dev. 12, 2598-2609 (1998).

80. O’Donovan, A., Davies, A. A., Moggs, J. G., West, S. C. \& Wood, R. D. XPG endonuclease makes the $3^{\prime}$ incision in human DNA nucleotide excision repair. Nature 371, 432-435 (1994).

81. Sijbers, A. M. et al. Xeroderma pigmentosum group F caused by a defect in a structure-specific DNA repair endonuclease. Cell 86, 811-22 (1996). 
82. Kelman, Z. PCNA: structure, functions and interactions. Oncogene 14, 629-640 (1997).

83. Moser, J. et al. Sealing of Chromosomal DNA Nicks during Nucleotide Excision Repair Requires XRCC1 and DNA Ligase III $\alpha$ in a Cell-Cycle-Specific Manner. Mol. Cell 27, 311-323 (2007).

84. DiGiovanna, J. J. \& Kraemer, K. H. Shining a Light on Xeroderma Pigmentosum. J. Invest. Dermatol. 132, 785-796 (2012).

85. Barnes, D. E. \& Lindahl, T. Repair and Genetic Consequences of Endogenous DNA Base Damage in Mammalian Cells. Annu. Rev. Genet. 38, 445-476 (2004).

86. Brooks, P. J. The 8,5'-cyclopurine-2'-deoxynucleosides: Candidate neurodegenerative DNA lesions in xeroderma pigmentosum, and unique probes of transcription and nucleotide excision repair. DNA Repair (Amst). 7, 1168-1179 (2008).

87. Laugel, V. Cockayne syndrome: The expanding clinical and mutational spectrum. Mech. Ageing Dev. 134, 161-170 (2013).

88. Kraemer, K. H. et al. Xeroderma pigmentosum, trichothiodystrophy and Cockayne syndrome: A complex genotype-phenotype relationship. Neuroscience 145, 13881396 (2007).

89. Theil, A. F. et al. Disruption of TTDA Results in Complete Nucleotide Excision Repair Deficiency and Embryonic Lethality. PLoS Genet. 9, e1003431 (2013).

90. de Boer, J. et al. Premature Aging in Mice Deficient in DNA Repair and Transcription. Science (80-. ). 296, 1276-1279 (2002).

91. Vermeulen, W. et al. A temperature-sensitive disorder in basal transcription and DNA repair in humans. Nat. Genet. 27, 299-303 (2001).

92. Gregg, S. Q., Robinson, A. R. \& Niedernhofer, L. J. Physiological consequences of defects in ERCC1-XPF DNA repair endonuclease. DNA Repair (Amst). 10, 781 (2011).

93. Niedernhofer, L. J. et al. A new progeroid syndrome reveals that genotoxic stress suppresses the somatotroph axis. Nature 444, 1038-1043 (2006). 
94. Jaspers, N. G. J. et al. First Reported Patient with Human ERCC1 Deficiency Has Cerebro-Oculo-Facio-Skeletal Syndrome with a Mild Defect in Nucleotide Excision Repair and Severe Developmental Failure. Am. J. Hum. Genet. 80, 457-466 (2007).

95. Bogliolo, M. et al. Mutations in ERCC4, Encoding the DNA-Repair Endonuclease XPF, Cause Fanconi Anemia. Am. J. Hum. Genet. 92, 800-806 (2013).

96. Kashiyama, K. et al. Malfunction of Nuclease ERCC1-XPF Results in Diverse Clinical Manifestations and Causes Cockayne Syndrome, Xeroderma Pigmentosum, and Fanconi Anemia. Am. J. Hum. Genet. 92, 807-819 (2013).

97. Kopper László. \& Schaff Zsuzsa. Patológia. (Medicina, 2004).

98. Kumar, V., Cotran, R. S. \& Robbins, S. L. A pathologia alapjai : [tankönyv]. (Semmelweis K, 1994).

99. Drilon, A. E., Postow, M. A. \& Varga Zoltán 1973-. Onkológiai kézikönyv. (Oriold, 2016).

100. PDQ Adult Treatment Editorial Board. Melanoma Treatment (PDQ $\left.{ }^{\circledR}\right)$ : Health Professional Version. PDQ Cancer Information Summaries (2002).

101. Oláh Judit, D. A. A melanoma malignum új TNM-beosztása. (2003).

102. Cakir, B. Ö., Adamson, P. \& Cingi, C. Epidemiology and economic burden of nonmelanoma skin cancer. Facial Plast. Surg. Clin. North Am. 20, 419-22 (2012).

103. Rubin, A. I., Chen, E. H. \& Ratner, D. Basal-Cell Carcinoma. N. Engl. J. Med. 353, 2262-2269 (2005).

104. Nguyen, T. H. \& Ho, D. Q.-D. Nonmelanoma skin cancer. Curr. Treat. Options Oncol. 3, 193-203 (2002).

105. Brougham, N. D. L., Dennett, E. R. \& Tan, S. T. THE NEW ZEALAND MEDICAL JOURNAL Non-melanoma skin cancers in New Zealand-a neglected problem. Journal of the New Zealand Medical Association NZMJ 123, (2010).

106. Xie, J. et al. Activating Smoothened mutations in sporadic basal-cell carcinoma. Nature 391, 90-92 (1998).

107. Gandhi, S. A. \& Kampp, J. Skin Cancer Epidemiology, Detection, and Management. Med. Clin. North Am. 99, 1323-35 (2015). 
108. Dubas, L. E. \& Ingraffea, A. Nonmelanoma skin cancer. Facial Plast. Surg. Clin. North Am. 21, 43-53 (2013).

109. Pleasance, E. D. et al. A comprehensive catalogue of somatic mutations from a human cancer genome. Nature 463, 191-196 (2010).

110. Drouin, R. \& Therrien, J. P. UVB-induced cyclobutane pyrimidine dimer frequency correlates with skin cancer mutational hotspots in p53. Photochem. Photobiol. 66, 719-26 (1997).

111. Hunt, L. T. \& Dayhoff, M. O. A surprising new protein superfamily containing ovalbumin, antithrombin-III, and alpha1-proteinase inhibitor. Biochem. Biophys. Res. Commun. 95, 864-871 (1980).

112. Carrell, R. \& Travis, J. $\alpha 1$-Antitrypsin and the serpins: variation and countervariation. Trends Biochem. Sci. 10, 20-24 (1985).

113. Irving, J. A. et al. Serpins in Prokaryotes. Mol. Biol. Evol. 19, 1881-1890 (2002).

114. Roberts, T. H., Hejgaard, J., Saunders, N. F. W., Cavicchioli, R. \& Curmi, P. M. G. Serpins in Unicellular Eukarya, Archaea, and Bacteria: Sequence Analysis and Evolution. J. Mol. Evol. 59, 437-447 (2004).

115. Schwarz, W. H. \& Zverlov, V. V. Protease inhibitors in bacteria: an emerging concept for the regulation of bacterial protein complexes? Mol. Microbiol. 60, 1323-1326 (2006).

116. Irving, J. A., Pike, R. N., Lesk, A. M. \& Whisstock, J. C. Phylogeny of the serpin superfamily: implications of patterns of amino acid conservation for structure and function. Genome Res. 10, 1845-64 (2000).

117. Roberts, T. H. \& Hejgaard, J. Serpins in plants and green algae. Funct. Integr. Genomics 8, 1-27 (2008).

118. Turner, P., Musy, P. \& Moyer, R. Viroceptors, virokines and related immune modulators encoded by DNA viruses. RG. (1995).

119. Heit, C. et al. Update of the human and mouse SERPIN gene superfamily. Hum. Genomics 7, 22 (2013).

120. Silverman, G. A. et al. The Serpins Are an Expanding Superfamily of Structurally 
Similar but Functionally Diverse Proteins. J. Biol. Chem. 276, 33293-33296 (2001).

121. Huber, R. \& Carrell, R. W. Implications of the three-dimensional structure of alpha 1-antitrypsin for structure and function of serpins. Biochemistry 28, 8951-66 (1989).

122. Dunstone, M. A. \& Whisstock, J. C. Crystallography of Serpins and Serpin Complexes. in Methods in enzymology 501, 63-87 (2011).

123. Billingsley, G. D., Walter, M. A., Hammond, G. L. \& Cox, D. W. Physical mapping of four serpin genes: alpha 1-antitrypsin, alpha 1-antichymotrypsin, corticosteroidbinding globulin, and protein $\mathrm{C}$ inhibitor, within a $280-\mathrm{kb}$ region on chromosome I4q32.1. Am. J. Hum. Genet. 52, 343-53 (1993).

124. Rollini, P. \& Fournier, R. E. K. A 370-kb Cosmid Contig of the Serpin Gene Cluster on Human Chromosome 14q32.1: Molecular Linkage of the Genes Encoding $\alpha 1$ Antichymotrypsin, Protein C Inhibitor, Kallistatin, $\alpha 1$-Antitrypsin, and Corticosteroid-Binding Globulin. Genomics 46, 409-415 (1997).

125. Rein, C. M., Desai, U. R. \& Church, F. C. Serpin-Glycosaminoglycan Interactions. in 105-137 (2011). doi:10.1016/B978-0-12-385950-1.00007-9

126. Long, M., de Souza, S. J. \& Gilbert, W. Evolution of the intron-exon structure of eukaryotic genes. Curr. Opin. Genet. Dev. 5, 774-778 (1995).

127. Logsdon, J. M., Stoltzfus, A. \& Doolittle, W. F. Molecular evolution: recent cases of spliceosomal intron gain? Curr. Biol. 8, R560-3

128. Izuhara, K., Ohta, S., Kanaji, S., Shiraishi, H. \& Arima, K. Recent progress in understanding the diversity of the human ov-serpin/clade B serpin family. Cell. Mol. Life Sci. 65, 2541-2553 (2008).

129. Izuhara, K., Ohta, S., Kanaji, S., Shiraishi, H. \& Arima, K. Recent progress in understanding the diversity of the human ov-serpin/clade B serpin family. Cell. Mol. Life Sci. 65, 2541-53 (2008).

130. Silverman, G. A. et al. Human clade B serpins (ov-serpins) belong to a cohort of evolutionarily dispersed intracellular proteinase inhibitor clades that protect cells from promiscuous proteolysis. Cell. Mol. Life Sci. 61, 301-25 (2004).

131. Remold-O'Donnell, E. The ovalbumin family of serpin proteins. FEBS Lett. 315, 
105-108 (1993).

132. Scott, F. L. et al. Human Ovalbumin Serpin Evolution: Phylogenic Analysis, Gene Organization, and Identification of New PI8-Related Genes Suggest That Two Interchromosomal and Several Intrachromosomal Duplications Generated the Gene Clusters at 18q21-q23 and 6p25. Genomics 62, 490-499 (1999).

133. Baker, M. S., Bleakley, P., Woodrow, G. C. \& Doe, W. F. Inhibition of cancer cell urokinase plasminogen activator by its specific inhibitor PAI-2 and subsequent effects on extracellular matrix degradation. Cancer Res. 50, 4676-84 (1990).

134. Sheng, S. et al. Tissue-type plasminogen activator is a target of the tumor suppressor gene maspin. Proc. Natl. Acad. Sci. U. S. A. 95, 499-504 (1998).

135. Kawano, T., Morimoto, K. \& Uemura, Y. Partial purification and properties of urokinase inhibitor from human placenta. J. Biochem. 67, 333-42 (1970).

136. Astedt, B., Lecander, I., Brodin, T., Lundblad, A. \& Löw, K. Purification of a specific placental plasminogen activator inhibitor by monoclonal antibody and its complex formation with plasminogen activator. Thromb. Haemost. 53, 122-5 (1985).

137. Åstedt, B., Bladh, B., Christensen, U. \& Lecander, I. Different inhibition of one and two chain tissue plasminogen activator by a placental inhibitor studied with two tripeptide-p-nitroanilide substrates. Scand. J. Clin. Lab. Invest. 45, 429-435 (1985).

138. Thorsen, S., Philips, M., Selmer, J., Lecander, I. \& Astedt, B. Kinetics of inhibition of tissue-type and urokinase-type plasminogen activator by plasminogen-activator inhibitor type 1 and type 2. Eur. J. Biochem. 175, 33-9 (1988).

139. Schroder, W. A., Major, L. \& Suhrbier, A. The role of SerpinB2 in immunity. Crit. Rev. Immunol. 31, 15-30 (2011).

140. Kruithof, E. K., Tran-Thang, C., Ransijn, A. \& Bachmann, F. Demonstration of a fastacting inhibitor of plasminogen activators in human plasma. Blood 64, 907-13 (1984).

141. Kruithof, E. K., Vassalli, J. D., Schleuning, W. D., Mattaliano, R. J. \& Bachmann, F. Purification and characterization of a plasminogen activator inhibitor from the histiocytic lymphoma cell line U-937. J. Biol. Chem. 261, 11207-13 (1986).

142. Genton, C., Kruithof, E. K. \& Schleuning, W. D. Phorbol ester induces the 
biosynthesis of glycosylated and nonglycosylated plasminogen activator inhibitor 2 in high excess over urokinase-type plasminogen activator in human U-937 lymphoma cells. J. Cell Biol. 104, 705-12 (1987).

143. Kruithof, E. K., Baker, M. S. \& Bunn, C. L. Biological and clinical aspects of plasminogen activator inhibitor type 2. Blood 86, 4007-24 (1995).

144. Wohlwend, A., Belin, D. \& Vassalli, J. D. Plasminogen activator-specific inhibitors produced by human monocytes/macrophages. J. Exp. Med. 165, 320-39 (1987).

145. Hamilton, J. et al. Macrophage colony-stimulating factor and granulocytemacrophage colony- stimulating factor stimulate the synthesis of plasminogenactivator inhibitors by human monocytes. Blood 82, (1993).

146. Ritchie, H., Jamieson, A. \& Booth, N. A. Regulation, location and activity of plasminogen activator inhibitor 2 (PAI-2) in peripheral blood monocytes, macrophages and foam cells. Thromb. Haemost. 77, 1168-73 (1997).

147. Swartz, J. M. et al. Plasminogen activator inhibitor-2 (PAI-2) in eosinophilic leukocytes. J. Leukoc. Biol. 76, 812-819 (2004).

148. Robinson, N. A., Lapic, S., Welter, J. F. \& Eckert, R. L. S100A11, S100A10, annexin I, desmosomal proteins, small proline-rich proteins, plasminogen activator inhibitor2 , and involucrin are components of the cornified envelope of cultured human epidermal keratinocytes. J. Biol. Chem. 272, 12035-46 (1997).

149. Akiyama, H., Ikeda, K., Kondo, H., Kato, M. \& McGeer, P. L. Microglia express the type 2 plasminogen activator inhibitor in the brain of control subjects and patients with Alzheimer's disease. Neurosci. Lett. 164, 233-5 (1993).

150. Antalis, T. M. et al. The serine proteinase inhibitor (serpin) plasminogen activation inhibitor type 2 protects against viral cytopathic effects by constitutive interferon alpha/beta priming. J. Exp. Med. 187, 1799-811 (1998).

151. Dickinson, J. L., Bates, E. J., Ferrante, A. \& Antalis, T. M. Plasminogen activator inhibitor type 2 inhibits tumor necrosis factor alpha-induced apoptosis. Evidence for an alternate biological function. J. Biol. Chem. 270, 27894-904 (1995).

152. Park, J. M. et al. Signaling Pathways and Genes that Inhibit Pathogen-Induced Macrophage Apoptosis - CREB and NF- $\mathrm{KB}$ as Key Regulators. Immunity 23, 319- 
329 (2005).

153. Risse, B. C. et al. Differentiating cells of murine stratified squamous epithelia constitutively express plasminogen activator inhibitor type 2 (PAI-2). Histochem. Cell Biol. 110, 559-69 (1998).

154. Andela, V. B., Schwarz, E. M., Puzas, J. E., O’Keefe, R. J. \& Rosier, R. N. Tumor metastasis and the reciprocal regulation of prometastatic and antimetastatic factors by nuclear factor kappaB. Cancer Res. 60, 6557-62 (2000).

155. Shafren, D. R., Gardner, J., Mann, V. H., Antalis, T. M. \& Suhrbier, A. Picornavirus receptor down-regulation by plasminogen activator inhibitor type 2. J. Virol. 73, 7193-8 (1999).

156. Kumar, S. \& Baglioni, C. Protection from tumor necrosis factor-mediated cytolysis by overexpression of plasminogen activator inhibitor type-2. J. Biol. Chem. 266, 20960-4 (1991).

157. Schroder, W. A. et al. SerpinB 2 deficiency modulates Th1/Th2 responses after schistosome infection. Parasite Immunol. 32, 764-8

158. Nakamura, M. et al. Possible role of plasminogen activator inhibitor 2 in the prevention of the metastasis of gastric cancer tissues. Thromb. Res. 65, 709-719 (1992).

159. Ito, H. et al. Prognostic relevance of urokinase-type plasminogen activator (uPA) and plasminogen activator inhibitors PAI-1 and PAI-2 in gastric cancer. Virchows Arch. 427, 487-96 (1996).

160. Ishikawa, N., Endo, Y. \& Sasaki, T. Inverse correlation between mRNA expression of plasminogen activator inhibitor-2 and lymph node metastasis in human breast cancer. Jpn. J. Cancer Res. 87, 480-7 (1996).

161. Yoshino, H., Endo, Y., Watanabe, Y. \& Sasaki, T. Significance of plasminogen activator inhibitor 2 as a prognostic marker in primary lung cancer: association of decreased plasminogen activator inhibitor 2 with lymph node metastasis. $B r . J$. Cancer 78, 833-9 (1998).

162. Shiiba, M. et al. Down-regulated expression of SERPIN genes located on chromosome 18q21 in oral squamous cell carcinomas. Oncol. Rep. 24, 241-9 (2010). 
163. Chou, R.-H. et al. Suppression of the invasion and migration of cancer cells by SERPINB family genes and their derived peptides. Oncol. Rep. 27, 238-245 (2011).

164. Mueller, B. M., Yu, Y. B. \& Laug, W. E. Overexpression of plasminogen activator inhibitor 2 in human melanoma cells inhibits spontaneous metastasis in scid/scid mice. Proc. Natl. Acad. Sci. U. S. A. 92, 205-9 (1995).

165. Antalis, T. M. et al. Cloning and expression of a cDNA coding for a human monocytederived plasminogen activator inhibitor. Proc. Natl. Acad. Sci. U. S. A. 85, 985-9 (1988).

166. van den Berg, E. A., le Clercq, E., Kooistra, T., Frants, R. R. \& Bakker, E. The human gene for plasminogen activator inhibitor 2 (PAI2) exhibits an EcoRI RFLP. Nucleic Acids Res. 18, 2837 (1990).

167. Mercado, M. V. et al. Genotype Ser ${ }^{413} /$ Ser of $P A I-2$ polymorphism Ser ${ }^{413} /$ Cys is associated with anti-phospholipid syndrome and systemic lupus erythematosus in a familial case: comparison with healthy controls. Scand. J. Rheumatol. 36, 206-210 (2007).

168. Palafox-Sánchez, C. A. et al. A functional Ser(413)/Ser(413) PAI-2 polymorphism is associated with susceptibility and damage index score in systemic lupus erythematosus. Clin. Appl. Thromb. Hemost. 15, 233-8 (2009).

169. Lee, J. A., Cochran, B. J., Lobov, S. \& Ranson, M. Forty years later and the role of plasminogen activator inhibitor type 2/SERPINB2 is still an enigma. Semin. Thromb. Hemost. 37, 395-407 (2011).

170. Di Bernardo, M. C., Matakidou, A., Eisen, T., Houlston, R. S. \& GELCAPS Consortium. Plasminogen activator inhibitor variants PAI-1 A15T and PAI-2 S413C influence lung cancer prognosis. Lung Cancer 65, 237-41 (2009).

171. Shioji, G. et al. Nucleotide variations in genes encoding plasminogen activator inhibitor-2 and serine proteinase inhibitor B10 associated with prostate cancer. $J$. Hum. Genet. 50, 507-15 (2005).

172. Przygodzka, P., Ramstedt, B., Tengel, T., Larsson, G. \& Wilczynska, M. Bomapin is a redox-sensitive nuclear serpin that affects responsiveness of myeloid progenitor cells to growth environment. BMC Cell Biol. 11, 30 (2010). 
173. Riewald, M. \& Schleef, R. R. Molecular cloning of bomapin (protease inhibitor 10), a novel human serpin that is expressed specifically in the bone marrow. J. Biol. Chem. 270, 26754-7 (1995).

174. Chuang, T. L. \& Schleef, R. R. Identification of a nuclear targeting domain in the insertion between helices $\mathrm{C}$ and D in protease inhibitor-10. J. Biol. Chem. 274, 11194-8 (1999).

175. Schleef, R. R. \& Chuang, T. L. Protease Inhibitor 10 Inhibits Tumor Necrosis Factor a-induced Cell Death. J. Biol. Chem. 275, 26385-26389 (2000).

176. Riewald, M. \& Schleef, R. R. Molecular cloning of bomapin (protease inhibitor 10), a novel human serpin that is expressed specifically in the bone marrow. J. Biol. Chem. 270, 26754-7 (1995).

177. Ujfaludi, Z. et al. Coordinated activation of a cluster of MMP genes in response to UVB radiation. Sci. Rep. 8, 2660 (2018).

178. Ziani, S. et al. Sequential and ordered assembly of a large DNA repair complex on undamaged chromatin. J. Cell Biol. 206, 589-98 (2014).

179. Lemaître, C. et al. Nuclear position dictates DNA repair pathway choice. Genes Dev. 28, 2450-63 (2014).

180. Johnson, M. R., Wang, K., Smith, J. B., Heslin, M. J. \& Diasio, R. B. Quantitation of Dihydropyrimidine Dehydrogenase Expression by Real-Time Reverse Transcription Polymerase Chain Reaction. Anal. Biochem. 278, 175-184 (2000).

181. Schroder, W. A. et al. A physiological function of inflammation-associated SerpinB2 is regulation of adaptive immunity. J. Immunol. 184, 2663-70 (2010).

182. Lee, J. A. et al. SerpinB2 (PAI-2) Modulates Proteostasis via Binding Misfolded Proteins and Promotion of Cytoprotective Inclusion Formation. PLoS One 10, e0130136 (2015).

183. Yang, S., Zheng, Y. \& Hou, X. Lipoxin A4 restores oxidative stress-induced vascular endothelial cell injury and thrombosis-related factor expression by its receptormediated activation of Nrf2-HO-1 axis. Cell. Signal. 60, 146-153 (2019).

184. Nagy, Z. et al. Tankyrases Promote Homologous Recombination and Check Point 
Activation in Response to DSBs. PLOS Genet. 12, e1005791 (2016).

185. Soutoglou, E. \& Misteli, T. Activation of the Cellular DNA Damage Response in the Absence of DNA Lesions. Science (80-. ). 320, 1507-1510 (2008).

186. Tumbar, T., Sudlow, G. \& Belmont, A. S. Large-scale chromatin unfolding and remodeling induced by VP16 acidic activation domain. J. Cell Biol. 145, 1341-54 (1999).

187. Sugasawa, K. et al. UV-Induced Ubiquitylation of XPC Protein Mediated by UVDDB-Ubiquitin Ligase Complex. Cell 121, 387-400 (2005).

188. Wang, Q.-E. et al. DNA repair factor XPC is modified by SUMO-1 and ubiquitin following UV irradiation. Nucleic Acids Res. 33, 4023-4034 (2005).

189. Shiomi, H., Eguchi, Y., Tani, T., Kodama, M. \& Hattori, T. Cellular Distribution and Clinical Value of Urokinase-Type Plasminogen Activator, Its Receptor, and Plasminogen Activator Inhibitor-2 in Esophageal Squamous Cell Carcinoma. Am. J. Pathol. 156, 567-575 (2000).

190. Champelovier, P. et al. Plasminogen- and colony-stimulating factor-1-associated markers in bladder carcinoma: diagnostic value of urokinase plasminogen activator receptor and plasminogen activator inhibitor type-2 using immunocytochemical analysis. Urol. Res. 30, 301-309 (2002).

191. Ramnefjell, M., Aamelfot, C., Helgeland, L. \& Akslen, L. A. Low expression of SerpinB2 is associated with reduced survival in lung adenocarcinomas. Oncotarget $\mathbf{8}$, 90706-90718 (2017).

192. Duggan, C. et al. Plasminogen activator inhibitor type 2 in breast cancer. Br. $J$. Cancer 76, 622-7 (1997).

193. Foekens, J. A. et al. The urokinase system of plasminogen activation and prognosis in 2780 breast cancer patients. Cancer Res. 60, 636-43 (2000).

194. Smith, R. et al. High Expression of Plasminogen Activator Inhibitor-2 (PAI-2) is a Predictor of Improved Survival in Patients with Pancreatic Adenocarcinoma. World J. Surg. 31, 493-502 (2007).

195. Daya-Grosjean, L. Xeroderma pigmentosum and skin cancer. Adv. Exp. Med. Biol. 
637, 19-27 (2008).

196. D’Orazio, J., Jarrett, S., Amaro-Ortiz, A. \& Scott, T. UV radiation and the skin. Int. J. Mol. Sci. 14, 12222-48 (2013).

197. Polyanka, H. et al. Primary characterization of a novel HPV-E6 oncogene immortalized keratinocyte cell line. J. Invest. Dermatol. 131, (2018).

198. Szlavicz, E. et al. Splicing factors differentially expressed in psoriasis alter mRNA maturation of disease-associated EDA+ fibronectin. Mol. Cell. Biochem. 436, 189199 (2017).

199. Kruithof, E. K., Baker, M. S. \& Bunn, C. L. Biological and clinical aspects of plasminogen activator inhibitor type 2. Blood 86, 4007-24 (1995).

200. Tasab, M., Batten, M. R. \& Bulleid, N. J. Hsp47: a molecular chaperone that interacts with and stabilizes correctly-folded procollagen. EMBO J. 19, 2204-2211 (2000).

201. Sweder, K. \& Madura, K. Regulation of repair by the 26 S proteasome. J. Biomed. Biotechnol. 2, 94-105 (2002).

202. Schauber, C. et al. $\operatorname{Rad} 23$ links DNA repair to the ubiquitin/proteasome pathway. Nature 391, 715-718 (1998).

203. Bregman, D. B. et al. UV-induced ubiquitination of RNA polymerase II: a novel modification deficient in Cockayne syndrome cells. Proc. Natl. Acad. Sci. U. S. A. 93, 11586-90 (1996).

204. Weeda, G. et al. The XPB subunit of repair/transcription factor TFIIH directly interacts with SUG1, a subunit of the 26S proteasome and putative transcription factor. Nucleic Acids Res. 25, 2274-83 (1997).

205. Ishikawa, N., Endo, Y. \& Sasaki, T. Inverse correlation between mRNA expression of plasminogen activator inhibitor-2 and lymph node metastasis in human breast cancer. Jpn. J. Cancer Res. 87, 480-7 (1996). 


\section{A dolgozatomban használt rövidítések}

6-4PP- 6-4 pirimidin-pirimidon fototermékek

$\alpha_{1}$ PI- $\alpha 1$-proteináz inhibítor

A375- melanoma sejtvonal

BCC- bazális sejtes karcinóma

BER- bázis kivágó hibajavítás (base excision repair)

BrdU- bromodeoxyuridine

BSA- bovine serum albumin

CETN2 fehérje- centrin 2

CSA- Cockayne-szindróma A fehérje

CSB- Cockayne-szindróma B fehérje

COFS betegséget- Cerebro-oculo- facio-skeletal syndrome

co-IP: ko-immunprecipitáció

COP9 (Constitutive photomorphogenesis 9)

CPD- ciklobután pirimidin dimerek

CRL- Cullin-RING ubiquitin ligase

Ct- cycle treshold

DCAF- DDB1 and CU14- associated factors

DDR- DNS hibára aktiválódó sejtválasz (DNA-damage response)

DMEM: Dulbecco's Modified Eagle Medium

DSB- kettős-szálú DNS törés (double strand break)

dsDNS- kettős-szálú DNS (double stranded DNA)

ELOA- Elongin A protein

FBS- Fetal Bovine Serum

GAM- Goat Anti Mouse

GAR- Goat Anti Rabbit

GFP- Green Fluorescent Protein

GG-NER- teljes genomra kiterjedő NER (global genomic NER)

$\mathrm{H}_{2} \mathrm{O}_{2}$ - hidrogén-peroxid

HA- hemagglutinin

HRP- torma-peroxidáz (Horseradish peroxidase)

ICL- interstrand crosslink 
$\mathrm{LD}_{50}$ - félletális dózis

mRNS- messenger ribonukleinsav

NAC- no antibody control

NCS- neocarzinostatin

NER- nukleotid kivágó hibajavítás (nucleotide excision repair)

NK- kezeletlen

NLS- nuclear localisation signal

nm- nanométer

NMSC- nem-melanoma típusú bőrtumorok (non-melanoma skin cancer)

PAI-2- Plasminogen activator inhibitor 2

PBS- Phosphate- buffered saline

PCNA- Proliferating cell nuclear antigen

PH domén- pleckstrin homology domain

PIC- Protease inhibitor cocktail

PolII- Polimeráz II

PTCH1- patched homolog 1

PTM- poszttranszlációs módosítás

qPCR- kvatitatív realt-time PCR (quantitative PCR)

RBX2- RING-box protein 2

RCL- reactive center loop

RFC- Replication factor C protein

ROS- reaktív oxigéngyök, (reactive oxigen species)

RPA- Replikációs protein A (Replication protein A)

RPB1- RNS polimeráz II legnagyobb alegysége

S2P Pol II-elongáló Polimeráz II

S2P RPB1-elongáló Polimeráz II

SCC- elszarusodó laphámrák

SCR- nem kódoló (scramble)

SMO- smoothened homolog gene

SP- Szerin proteáz inhibítor

SPB- Serpin B család

SPB2- SerpinB2 fehérje

SPB10- SerpinB10 fehérje

SSA repair- single-strand anneling 
ssDNS- egyes-szálú DNS (single stranded)

TC-NER- transzkripció kapcsolt NER (transcription coupled NER)

TFIIH- Transzkripciós Faktor II H

tPA- tissue plasminogen activator

U2OS- oszteoszarkóma sejtvonal

Ub- ubiquitin

uPA- urokinase plasminogen activator

UPS- ubiquitin-proteasome system

USP7- Ubiquitin specific-processing protease 7

UV- ultraibolya

UV-DDB- Ultraviolet radiation- DNA damage- binding protein

UVSSA- UV-stimulated scaffold protein A

$\mathrm{XP}$ - Xeroderma pigmentosum

XPB- Xeroderma pigmentosum B

XPC- Xeroderma pigmentosum C 


\section{Publikációs lista}

\section{$\underline{\text { A disszertáció alapjául szolgáló publikáció(k): }}$}

SerpinB2 is involved in cellular response upon UV irradiation

Hajnalka Majoros, Zsuzsanna Ujfaludi, Barbara Nikolett Borsos, Viktória Vivien Hudacsek, Zita Nagy, Frederic Coin, Krisztina Buzas, Ilona Kovács, Tamás Bíró, Imre Miklós Boros, Tibor Pankotai

Sci.Rep. 2019 Feb 26; 9 (1): 2753. doi: 10.1038/s41598-019-39073-w

Coordinated activation of a cluster of MMP genes in response to UVB radiation Zsuzsanna Ujfaludi, Agota Tuzesi, Hajnalka Majoros, Balint Rothler, Tibor Pankotai, Imre Miklós Boros

Sci.Rep. 2018 Feb 8; 8(1):2660. doi: 10.1038/s41598-018-20999-6

\section{Egyéb publikációk:}

Quantification of DNA damage induced repair focus formation via super-resolution dSTORM localization microscopy

Dániel Varga*, Hajnalka Majoros*, Zsuzsanna Ujfaludi, Miklós Erdélyi, Tibor Pankotai Nanoscale 2019 Jún 30; doi:10.1039/C9NR03696B

Human p53 interacts with the elongating RNAPII complex and is required for the release of actinomycin D induced transcription blockage

Barbara Nikolett Borsos, Ildiko Huliák, Hajnalka Majoros, Zsuzsanna Ujfaludi, Péter Pukler, Imre Miklos Boros, Tibor Pankotai

Sci.Rep. 2017 Jan 19;7:40960. doi:10.1038/srep40960.

Detection of invasive fungal pathogens by real-time PCR and high-resolution melting analysis.

Ferenc Somogyvari, Adam Horvath, Julianna Serly, Hajnalka Majoros, Csaba Vagvolgyi, Zoltan Peto

In Vivo 2012 Nov-Dec; 26(6):979-83 


\section{Támogatások}

- A genom instabilitás és a karcinogenezis molekuláris térképezése, MolMedEx TUMORDNS GINOP-2.3.2-15-2016-00020

- Multimoduláris optikai nanoszkópiai módszerek fejlesztése és alkalmazása az életés anyagtudományi kutatásban, GINOP-2.3.2-15-2016-00036

- Nem-invazív szérumdiagnosztikán és adatintegráción alapuló piacképes diagnosztikai prototípus kit készítése, GINOP-2.2.1-15-2017-00052

- Campus France ösztöndíj, 856706J 